\title{
الدعم التنظيمي المدرك وعلاقته بالالتزام التنظيمي لدى معلمي مدارس التعليم العام بمحافظة أضيم
}

\section{حامد بن جعفر عبدالله المالكي}

وزارة التربية والتعليم- المملكة العربية السعودية

7galmalki@gmail.com

هدفت الدراسة الحالية إلى التعرف على مستوى الدعم التنظيمي المدرك بمدارس التعليم العام بمحافظة أضم، ومستوى الالتزام التنظيمي

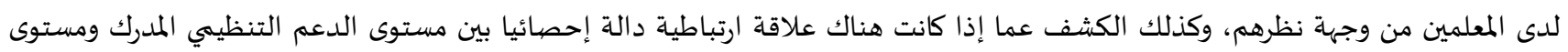

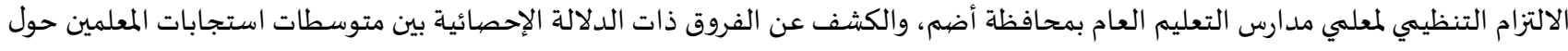

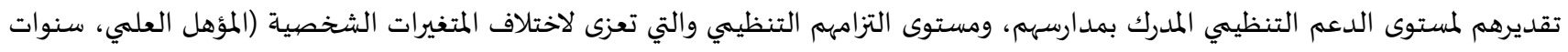

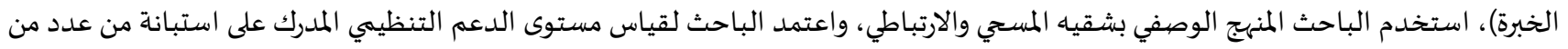

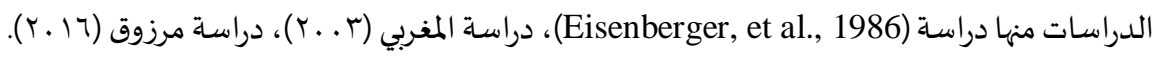

الكلمات المفتاحية: الدعم التنظيمي؛ التعليم العام؛ الالتزام التنظيمي؛ أضم. @()

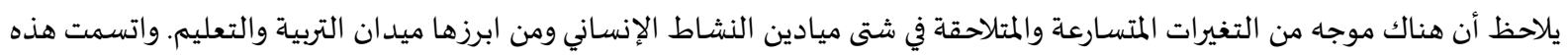

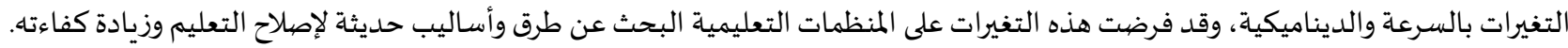

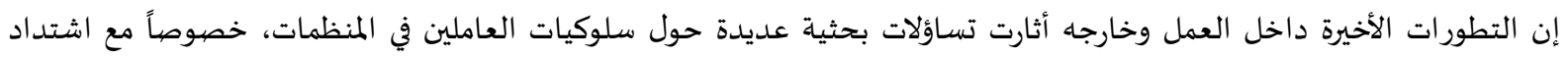

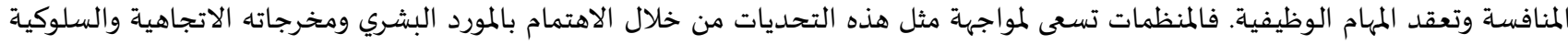

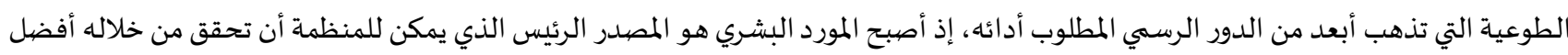

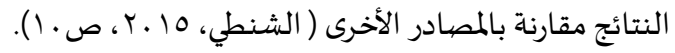

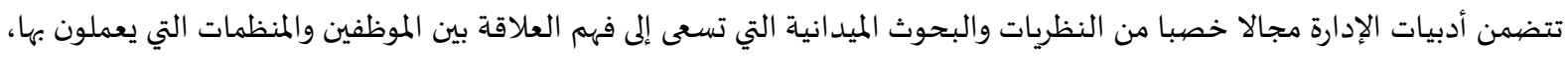

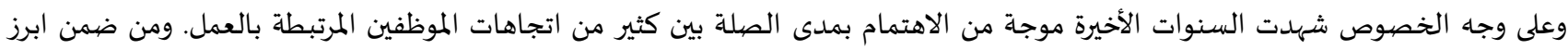

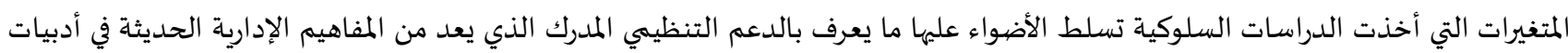

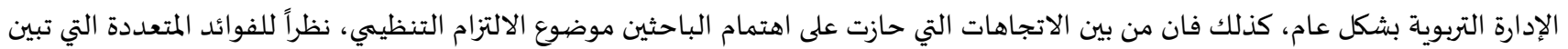

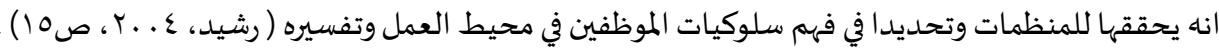

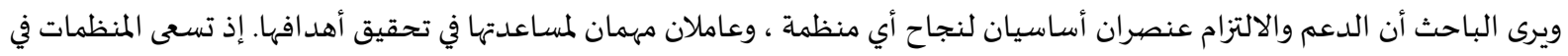

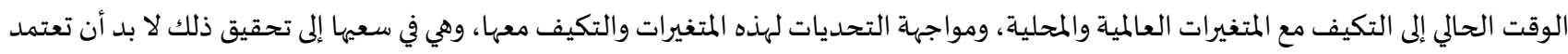

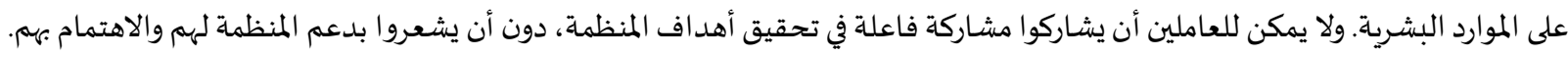

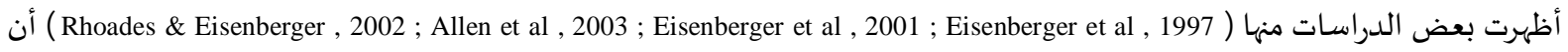
الدعم التنظيمي المدرك من محددات الالتزام التنظيمي، فضلاً عن أن الالتزام التنظيمي يتطور نتيجة للخبرات التي تشبع حاجة الموظفين إلى الشعور 
بالارتياح المادي والنفسي في المنظمة، لذا يمكن النظر إلى الدعم التنظيمي المدرك على انه ثقة والتزام من قبل المنظمة لموظفهها، حيث أن إدراك الموظف

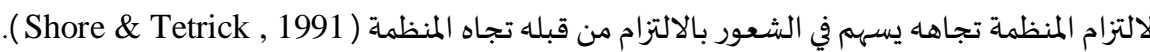
وفي ضوء ما تقدم فإن الباحث يسعى من خلال هذه الدراسة لرصد العلاقة بين الدعم التنظيمي المدرك وعلاقته بالالتزام التنظيمي بمدارس التعليم العام بمحافظة أضمر من وجهة نظر معلميها.

مشكلة الدراسـة:

أحد الأطر التي ظهرت مؤخراً لتفسير العوامل التي تؤثر في الاتجاهات نحو العمل وسلوكيات الموظف تم استقاؤها من نظرية التبادل

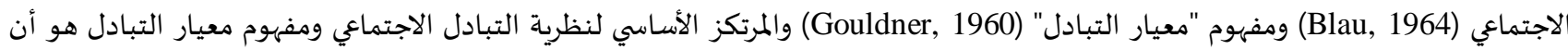

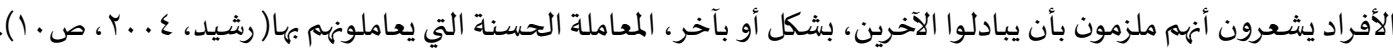

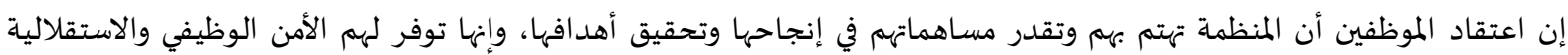
والتدريب، سينعكس ذلك إيجاباً بزيادة الرضيا الوظيفي وتعظيم الإنجاز والانتماء للمنظمة والوصول لسلوك المواطنة التنظيمية. ودعمت الدراسات

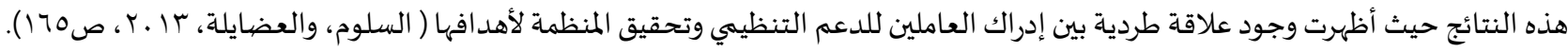
يعتبر المعلمون من العناصر البشرية التي لها دورها المركزي في قدرة المدرسة على تحقيق أهدافها من خلال تنفيذ المهام والواجبات المهرديات المهنية

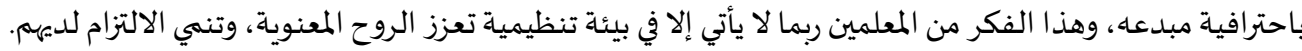

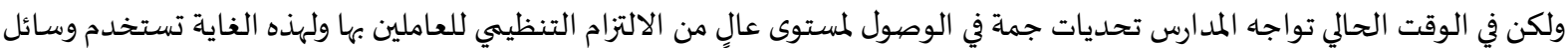

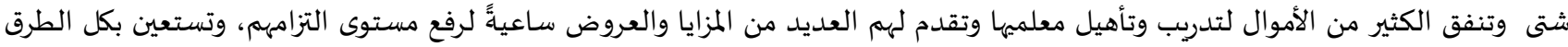

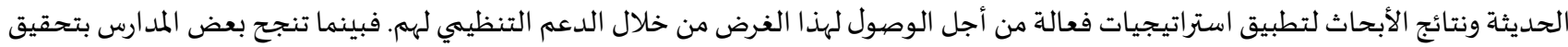
الالتزام التنظيمي من خلال وسائل الدعم التنظيمي، قد تخفق مدارس أخرى تستخدم نفس الوسائل وذلك بسبب اختلاف نشاط المدرسة والمكان

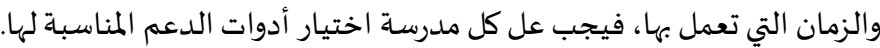
ومن خلال خبرتي بالعمل معلماً ثم مدير مدرسة فقد تولد لدي احساس بضرورة معرفة مستوى الدعم التنظيمي المدرك لدى معلمي مدارس التعليم العام بمحافظة أضهم وهل له علاقه بالتزامهم التنظيمي.

أسئلة الدراسـة: وتأسيساً على ما سبق فقد تبلورة المشكلة في معرفة مستوى الدعم التنظيمي المدرك لدى معلمي مدارس التعليم العام بمحافظة أضهم وعلاقته بالتزامهه التنظيمي، وعليه يمكن صياغة مشكلة الدراسة في السؤال الرئيس التالي: ما مستوى الدعم التنظيمي المدرك لدى معلمي مدارس التعليم العام بمحافظة أضهم وما علاقته بالتزامهم التنظيمي؟

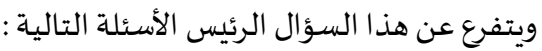
ا. ما مستوى الدعم التنظيمي المدرك الذي تقدماء مدارس التعليم العام بمحافظة أضمى للمعلمين العاملين بها من وجهة نظرهم؟

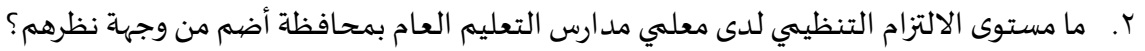

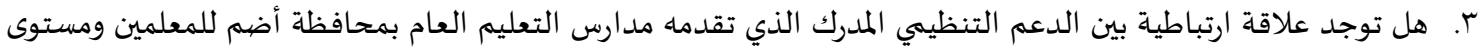
الالتزام التنظيمي لديهم ؟ توج ع. هل توجد فروق ذات دلالة إحصائية بين متوسطات استجابات معلمي مدارس التعليم العام بمحافظة أضم حول الدعم

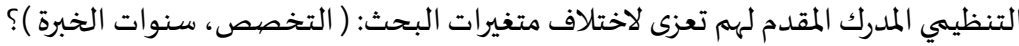
0. هل توجد فروق ذات دلالة إحصائية بين متوسطات استجابات معلمي مدارس التعليم العام بمحافظة أضمى حول تقديرهم

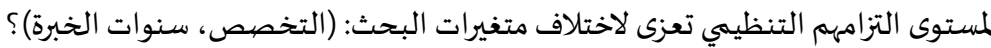

أهداف الدراسـة: تتمثل أهداف الدراسة الحالية فيما يلي : ا. التعرف على مستوى الدعم التنظيمي المدرك الذي تقدمه مدارس التعليم العام بمحافظة أضم للمعلمين العاملين بها من وجهة نظرهم؟

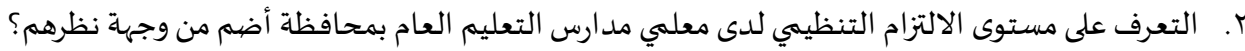

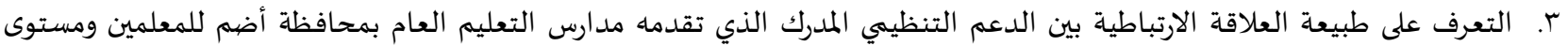

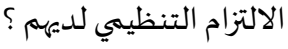


ع. الكشف عن الفروق ذات الدلالة الإحصائية بين متوسطات استجابات معلمي مدارس التعليم العام بمحافظة أضهم حول الدعم التنظيمي

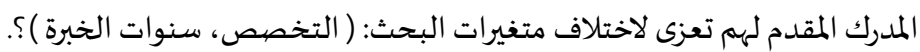
0. الكشف عن الفروق ذات الدلالة الإحصائية بين متوسطات استجابات معلمي مدارس التعليم العام بمحافظة أضهم حول تقديرهم لمستوى

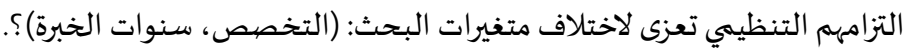

أهمية الدراسـة:

يمكن بيان أهمية البحث من خلال المحاور التالية: ا. من المؤمل أن تسهم دراسة الدعم التنظيمي في مدارس التعليم العام بمحافظة أضمى وربطه بالالتزام التنظيمي في فهم هذه العلاقة، ومن ثم تمكين هذه المدارس من اتخاذ الخطوات العملية لتهيئة البيئة التي تساعد على الاستفادة من نتائج الدراسة، الأمر الذي سينعكس في نهاية الأمر على فاعليتها وكفاءتها. r. تكتسب هذه الدراسة أهمية خاصة،، لكونها من الأبحاث القليلة التي تربط بين الدعم التنظيمي المدرك والالتزام التنظيهي، لا بل أن العديد من

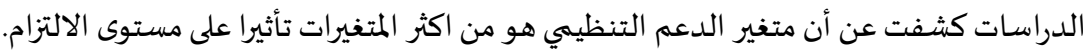

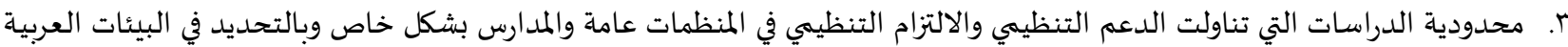
نسبيا في حدود علم الباحث، وبالتالي فان هذه الدراسـة سوف تكون إضافة علمية. ع. ق قد تساعد نتائج هذا البحث وتوصياته الباحثين الجدد على بلورة مشكلههم البحثية ووضيوح طبيعة العلاقة بين الدعم التنظيمي المدرك والالتزام التنظيمي.

حدود الدراسـة: تتمثل حدود هذا البحث في: الحدود الموضوعية: يقتصر هذا البحث على تحديد العلاقة بين الدعم التنظيمي المدرك بمحدداته التالية: العدالة التنظيمية، سلوك القادة لمساندة المرؤوسين، المشاركة في اتخاذ القرارات، دافعية الإنجاز لدى العاملين، وعلاقته بالالتزام التنظيمي لدى المعلمين في أبعاده التالية: الالتزام الوجداني(العاطفي)، والالتزام الاستمراري(البقائي)، والالتزام المعياري(الأخلاقي).

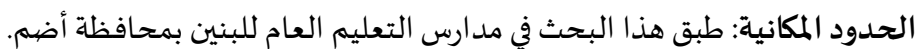
الحدود البشرية: طبق هذا البحث على معلمي مدارس التعليم العام للبنين بمحافظة أضمى مدام

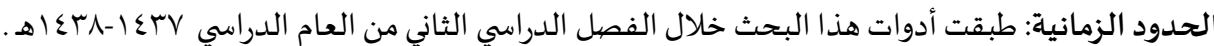

مصيطلحات الدراسـة: - مصات

تتمثل مصطلحات البحث في مصطلحين رئيسيين هما:

ا ـ الدعم التنظيمي المدرك (Perceived Organizational Support) : ويعرف الدعم التنظيمي المدرك إجرائياً بأنها عبارة عن السياسات والإجراءات التنظيمية التي تتبناها مدارس التعليم العام وتمارسها من خلال تحقيق العدالة والمساواة بين المعلمين، وكذلك مشـاركتهم في اتخاذ القرارات، وتحقيق ذواتهم ورغباتهم وتطلعاتهم وذلك أجل تشجيعهم وتحفيزهم لتبني أهداف المدرسة والعمل على تحقيقها.

ب. (Organizational Commitment) : الالتزام التنظيمي

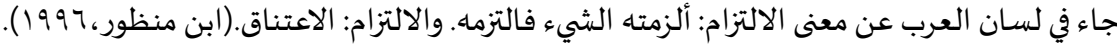
وتعددت تعريفات الالتزام التنظيمي منها : "تماثل قيم الفرد ومعتقد اته وأهدافه مع قيم المؤسسة ومعتقداتها وأهدافها ولبذل لأقصى جهد مستطاع لتحقيق أهدافها والمحافظة على العضوية فيها" (Meyer,1993).

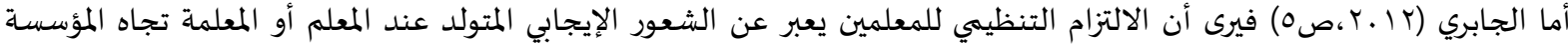
التعليمية والارتباط بها، والإخلاص لها مع قيمها وأهد افها والحرص على البقاء بها، من خلال بذل الجهام الجهد والسعي والقيام بكل ما يؤدي إلى نجاح المؤسسة المها وتفضيلها على ما سواها مع الافتخار بمآثر المؤسسة التعليمية مما يعزز نجاحها. 
ويعرف الباحث الالتزام التنظيمي إجرائياً في هذه الدراسة بأنه الشعور الإيجابي المتولد عند المعلمين تجاه مدارسهم وانتماؤهم لها، ورغبتهم

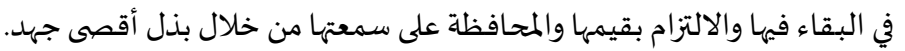

\section{أولاً: الإطار النظري والدراسات السابقة:}

تمهييد:

ترتبط فاعلية أي منظمة بكفاءة العنصر البشري وقدرته على العمل ورغبته فيه باعتباره العنصر المؤثر، والفعال في استخدام الموارد

المادية المتاحة. وتعتمد الإدارة في تحقيق النجاح وزيادة الانتاجية على ترشيد استخدام تلك الموارد المادية والبشرية. وقد يصعب ترشيد استخدام العنصر البشري لتعدد المتغيرات المحددة له، لدرجة تزيد من صعوبة قدرة الإدارة على ترشيد استخدام هذا العندئ العنصر وهو الأمر الذي جعل المشكلة

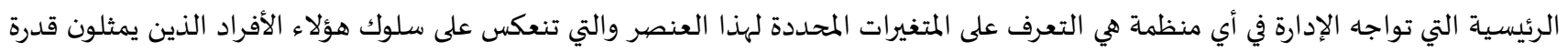

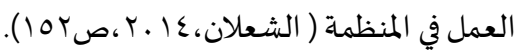

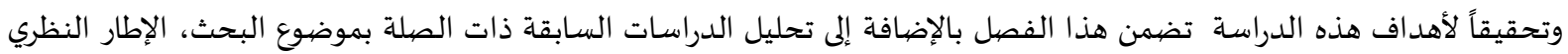

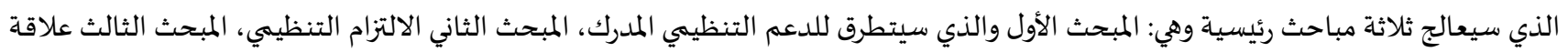
الدعم التنظيمي بالالتزام التنظيمي. وذلك على النحو التالي:

\section{المبحث الأول: الدعم التنظيمي المدرك Perceived Organizational Support:}

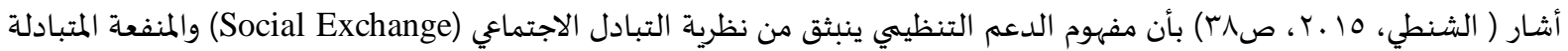

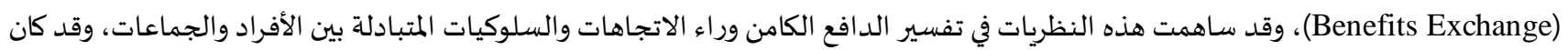
للباحث إيزينبيرجر (Eisenberger) المساهمة الأكبر في مجال تطبيق هاتين النظريتين وتوظيفهما لأجل بيان وتفسير العلاقة بين المنظمة والموظفين

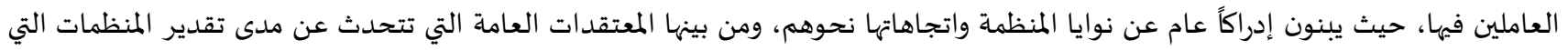

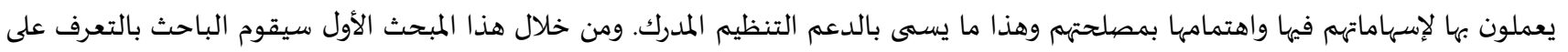
المفاهيم والتعاريف الأساسية لمفهوم الدعم التنظيمي المدرك وكذلك أهمية الدعم التنظيمي المدرك للمد ارس وفوائده وأيضا سيتطرق الباحث لأبعاده

والعوامل المؤثرة فياه.

Eisenberger, Rhoades, ) مفهوم الدعم التنظيهي المدرك: أثار الدعم التنظيمي قدراً كبيراً من الاهتمام بين الباحثين في مجالات علم النفس والإدارة 2002). وقد تم تعريف الدعم التنظيمي المدرك بطرق مختلفة حيث أكد (Eisenberger, 1986) بأن الدعم التنظيمي المدرك يشير إلى اعتقاد العاملين

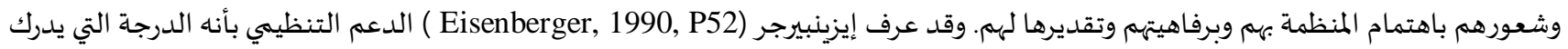

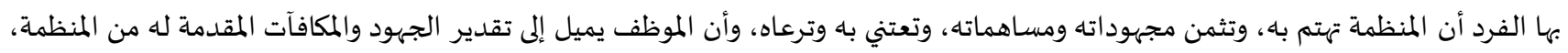
ويرى بأنها تقدر مساهمة الموظفين، وتهتم برفاهيتهم.

ويمكن تعريف الدعم التنظيمي المدرك بأنه إدراك العاملين لجميع أشكال المساعدات الماديادية والمعنوية والتي تمنحهها المنظمة بشكل طوعي

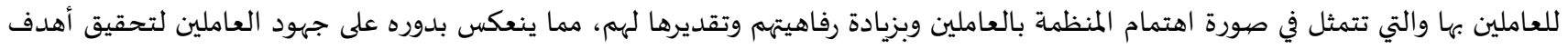

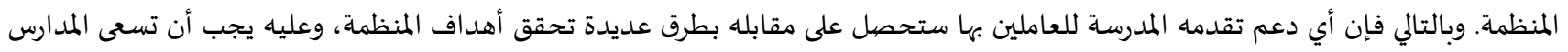

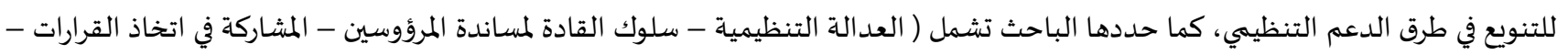
دعم وتأكيد الذات لدى العاملين ).

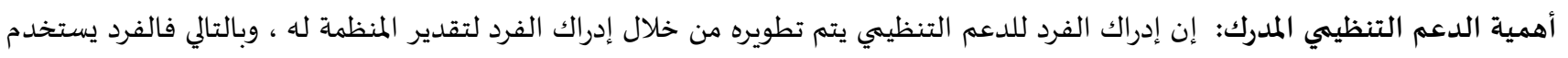

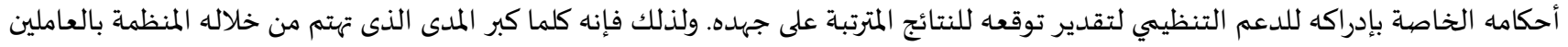

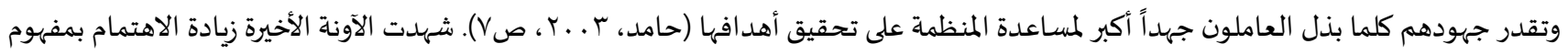

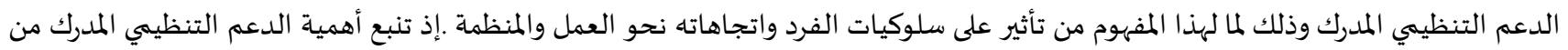

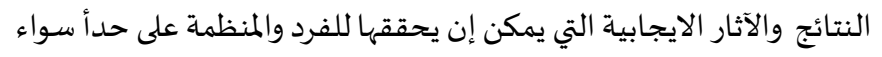




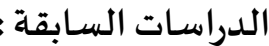

تمت الاستفادة من عدد لا بأس بهاه من الدراسات في إعداد ودعم هذا المخطط البحثث، وتم عرض الدراسات السابقين في محورين، وسيتم ترتيبها من الأحدث إلى الأقدم، من خلال عرض أهدافها ومنهجيتها وأبرز النتائج والتوصيات ذات التات الصنلة بالدراسة الحالية، كما يلي:

الدراسات المتعلقة بالدعم التنظيهي المدرك:

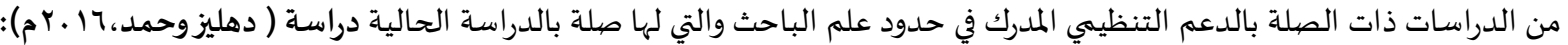

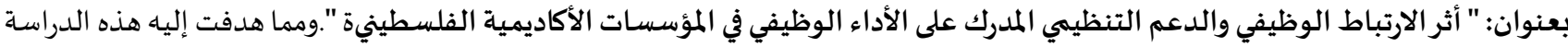

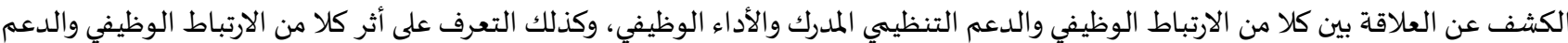

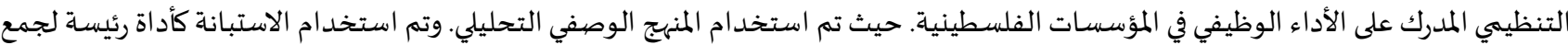

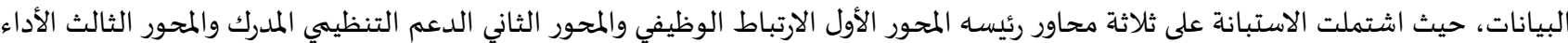

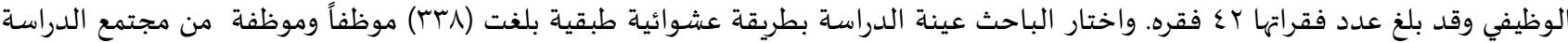
المكون من (ع ـ11) موظفاً وموظفة من الإداريين والأكاديميين أصحاب المناصب الإدارية في الجامعات الثلاث (الجامعة الإسلامية، جامعة الأزهر،

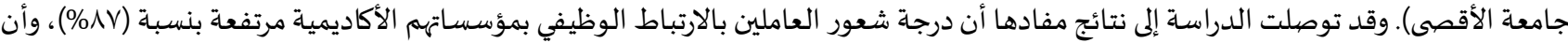

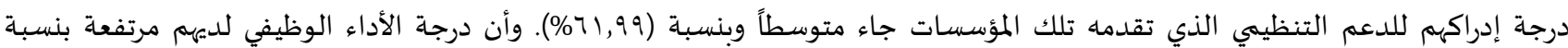
(r,r,r\%). وأن هناك علاقة ذات دلالة إحصائية بين كلاً من الارتباط الوظيفي والدعم التنظيمي المدرك والأداء الوظيفي في المؤسسات الأكاديمية.

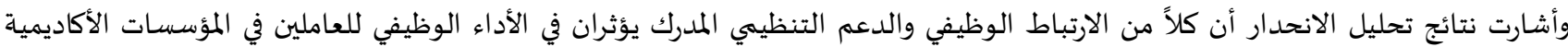

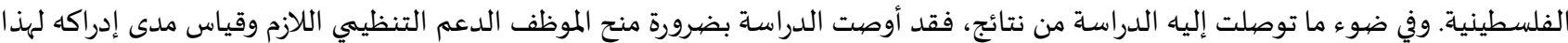
الدعم وضرورة إحداث التوافق بين الأهداف الشخصية للموظفين وأهداف المؤسسة الأكاديمية، كما أصوت الدراسة بتوطيد العلاقات الإنسانية بين إلين

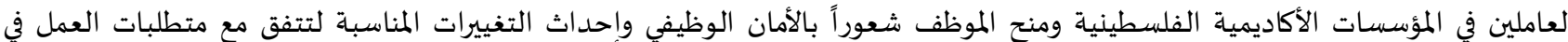
المؤسسات الأكاديمية الفلسطينية.

وفي جانب تقييم الدعم التنظيمي المدرك ودوره في رفاهية المعلمين قام (مليك، Malik, 2015 بدراسة هدفت إلى تقييم الدعم التنظيمي

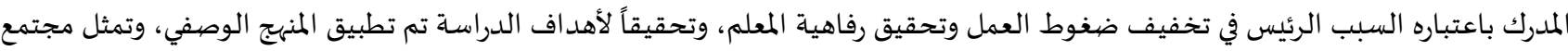

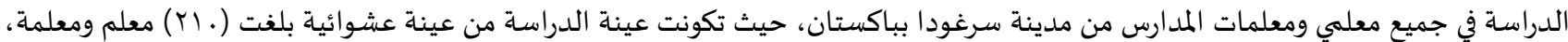

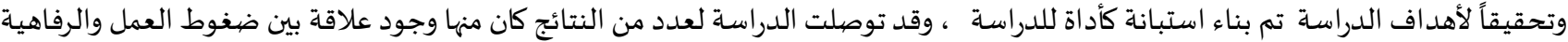
لدى المعلمين، كما أن الدعم التنظيمي المدرك يمثل السبب الرئيس في تحقيق الرفاهية للمعلمين، وفي حالة إدراكه يصبح سبباً في تخفيف ضئفاء

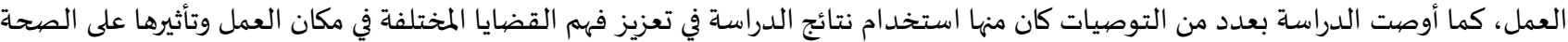
النفسية ورفاهية الموظفين، والعمل على كشف عوامل الإجهاد في المؤسسات التعليمية المختلفة.

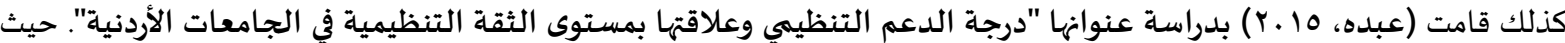
هدفت هذه الدراسة إلى تقصي درجة الدعم التنظيمي وعلاقتها بمستوى الثقة التنظيمية في الجامعات الأردنية، من وجاه نظر أعضاء أعضاء هيئة التدريس. واستخدمت الباحثة في هذه الدراسة المنهج الوصفي الارتباطي، وقد تكون مجتمع الدراسة من أعضاء هيئة التدريس في الجامعات الأردنية الرسمية وتم

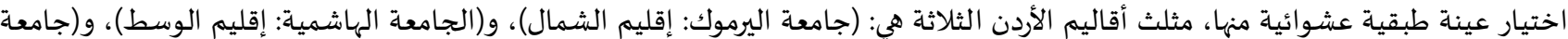

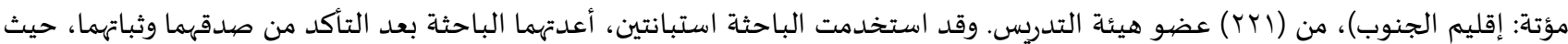

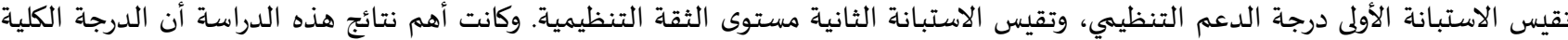
للدعم التنظيمي في الجامعات الأردنية متوسطة، حيث لم يكن هناك فروق ذات التات دلالة إحصائياً بين متوسطات إجابة عينة الدراسة، فيما يتعلق بدرجة الدانة

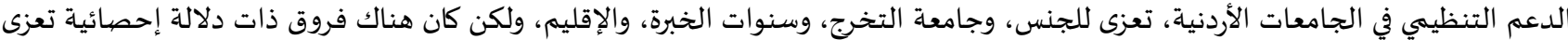

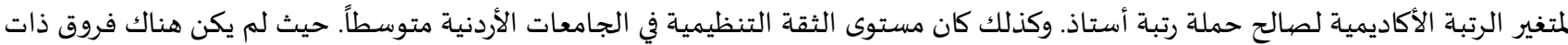

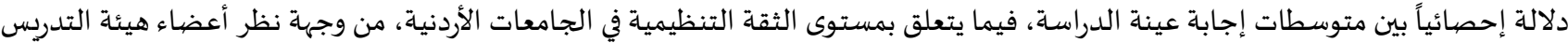

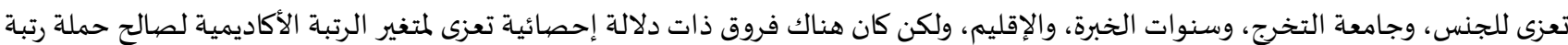
أستاذ. وعليه فقد أوصت الباحثة باتخاذ إجراءات لتعزيز الدعم التنظيمي والثقة التنظيمية، والقيام بدراسات حول الدعم التئية التنظيمي والثقة التنظيمية وعلاقتهما بالاحتراق النفسي، والعدالة التنظيمية، والصمت التنظيمي، والأمن الوظيفي، والثقافة التنظيمية، والصححة التنظيمية، والالتزام التنظيمي، والأداء الوظيفي، والولاء التنظيمي، والاغتراب. 
التعقيب على الدراسـات السـابقة للدعم التنظيمي المدرك: بعد الاطلاع على الدراسات السابقة للدعم التنظيمي المدرك في مجتمعات مختلفة محلية وعربية وأجنبية، وجدت تشابهات بين تلك الدراسات ودراستي في بعض الجوانب، ووجدت كذلك اختلافا في جوانب أخرى، وفيما يلي عرض لأبرز تلك الجوانب:

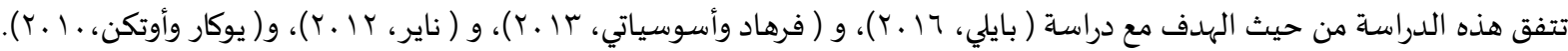

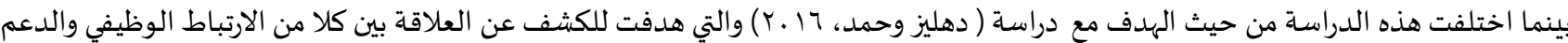
التنظيمي المدرك والأداء الوظيفي. ودراسة (Malik, 2015) والتي هدفت إلى تقييم الدعم التنظيمي المدرك باعتباره السبب الرئيس في تخفيف ضغوط العمل وتحقيق رفاهية المعلم. ودراسة (عبده، 10 ــ) حيث هدفت هذه الدراسة إلى تقصي درجة الدعم التنظيمي وعلاقتها بمستوى الثقة التنظيمية في

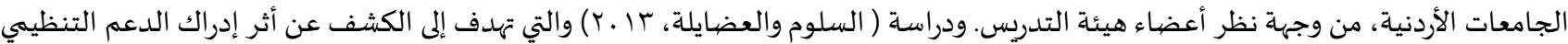

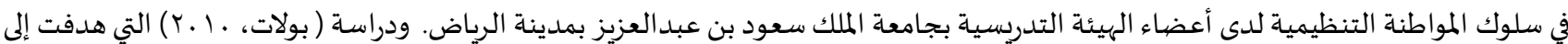
تقييم تأثير الدعم التنظيمي المدرك للمعلم على الثقة التنظيمية بمدارسههم. استخدم الباحث في دراسته المنهج الوصفي بشقيه (المستي، والارتباطي) باعتباره أنسب المناهج لمثل هذه الدراسات، واختلفت معه في

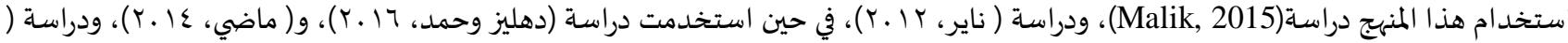

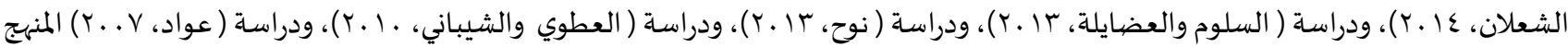

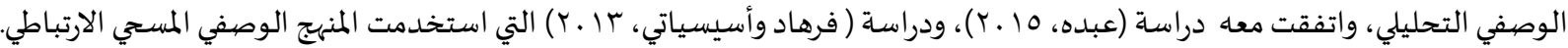

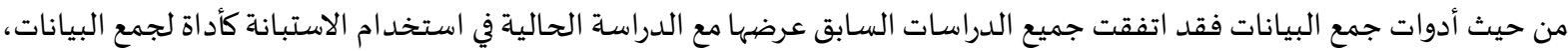

ولكنها اختلفت في طريقة بناء وتصيميم واعداد الاستبانة أو تطبيق استبانة معدة سلفاً.

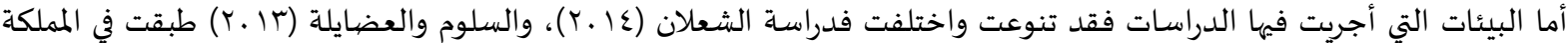

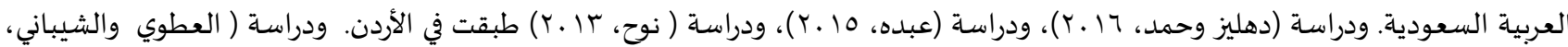

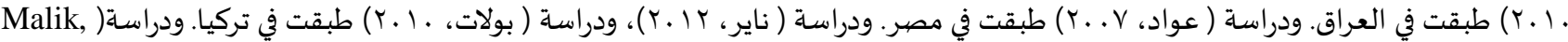

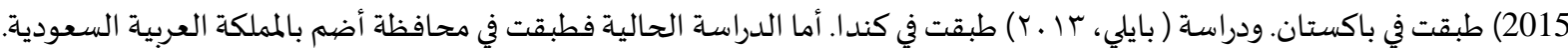
ومن خلال استعراض الدراسات السابقة نجد أن هناك اختلافاً في مجال العمل أو المؤسسـة: حيث تتفق الدراسة الحالية مع دراسة

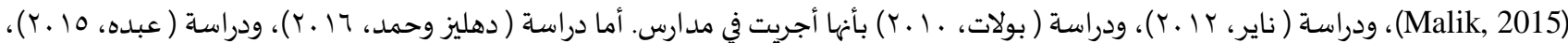

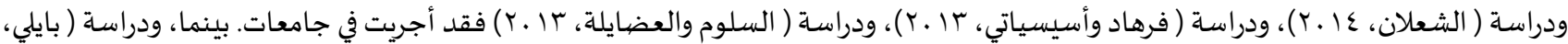

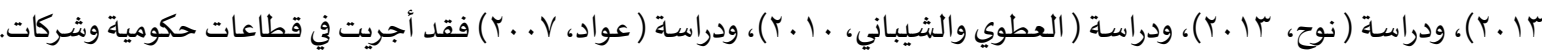

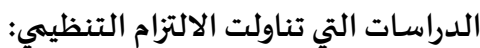

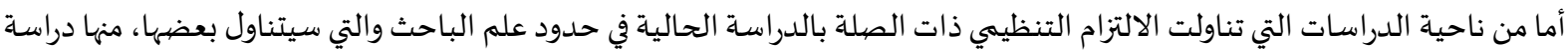
كليبي وكوريوماز (Celebi \&Korumaz, 2016) بدراسة هدفت إلى معرفة العلاقة بين ولاء المعلمين لمديريهم والتزامهم التنظيمي لمدارسهمه. وتم تطبيق

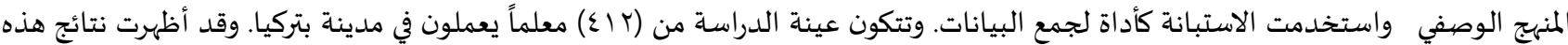

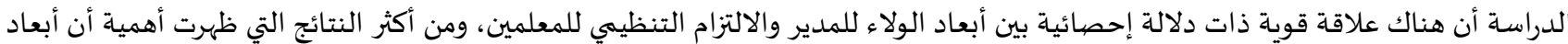
الالتزام وهي الالتزام الوجداني والالتزام الاستمراري والالتزام المعياري قد تنبأت بأبعاد مختلفة مع ولاء المعلمين لمديريهم. وأن الالتزام العاطفي القوي

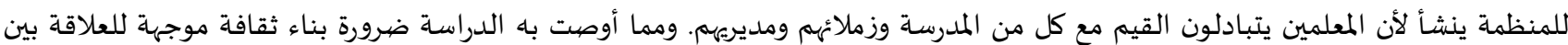

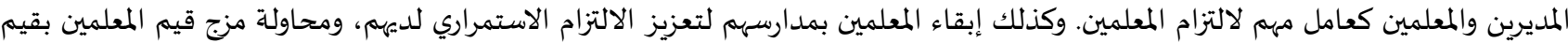
المدرسة لتحقيق الالتزام القيمي مما يعني استعداد الأفراد للحفاظ على التزامههم لفترة طويلة. أما (قناديلي وقاروت، 10 ـ ب) فقد أجريا دراسة هدفت للتعرف على مستوى الالتزام التنظيمي لدى معلمات صفوف المرحلة المتوسطة

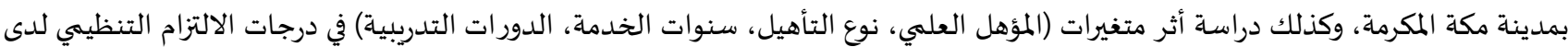
معلمات صفوف المرحلة المتوسطة بمدينة مكة المكرمة، وكذلك تحديد نوع الالتزام التنظيمي في صفوف المرحلة المتوسطة بمدينة مكة المكرمة. وقد تم استخدم المنهج الوصفي التحليلي. وقد تم اخذ عينة عشوائية حيث بلغ مجموع عدد الاستبانات المكتملة والتي ادخلت في عملية التحليل الاحصائي

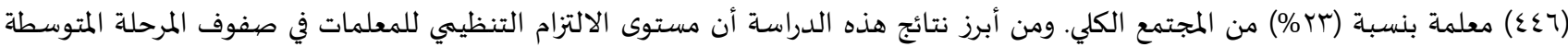

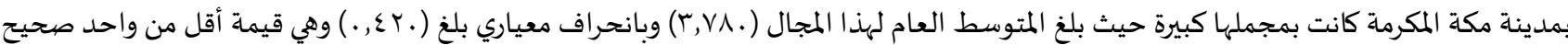

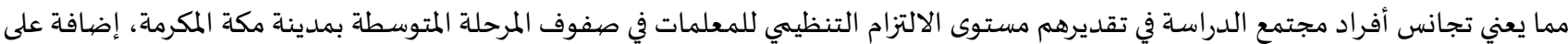
ذلك لا توجد فروق ذات دلالة إحصائية حول درجة الالتزام التنظيمي لمعلمات صفوف المرحلة المتوسطة بمدينة مكة المكرمة تعزى لمتغير (المؤهل 
العلمي، نوع التأهيل، سنوات الخدمة، الدورات التدريبية). ومن أبرز التوصيات التي تضمنتها الدراسة التأكيد على تعزيز مفهوم الالتزام التنظيمي من

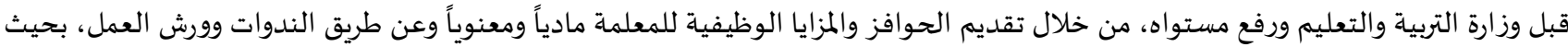
يكون تعزيز الممارسات الإيجابية لها بما يخدم أهداف المنظماة، وأن تعمل إدارة التربية والتعليم في مناطق المملكاة على تكثيف عقد الدورات التدرببية أثناء الخدمة.

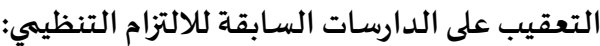
من خلال استعراض الدراسات السابقة لم نجد دراسة على حد علم الباحث تربط بين الدعم التنظيمي المدرك والالتزام التنظيمي للمعلمين.

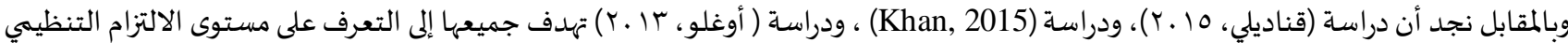

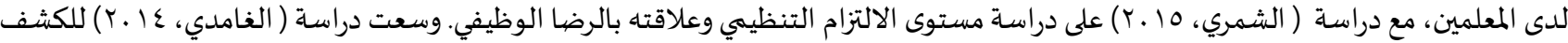

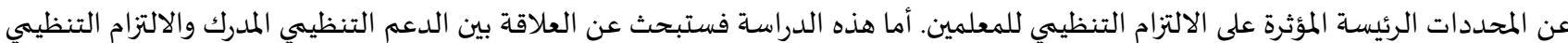

لدى المعلمين كأول دراسة على حد علم الباحث تجرى داخل الوطن العربي تربط بين هذين المتغيرين داخل البيئة التعليمياة.

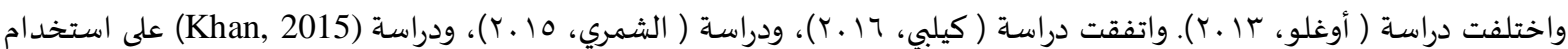

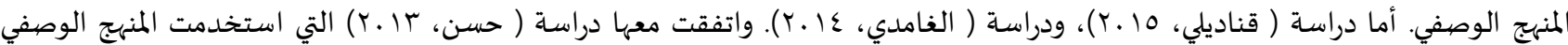

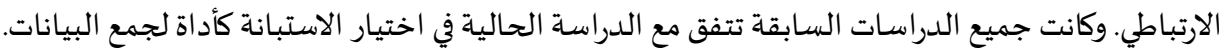

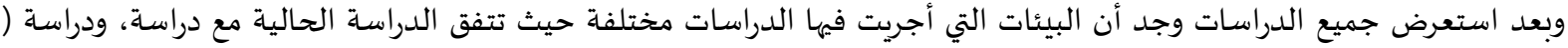

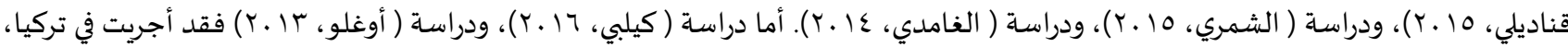

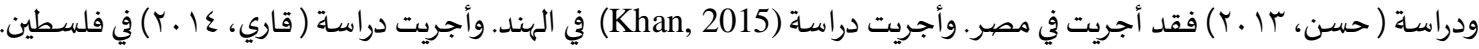

التعقيب على الدراسات السابقة:

ا. للدراسات السابقة دور في تعزيز الدراسة الحالية وإيضاح مساراتها، فقد كون الباحث رؤية مكنته من صياغة مشكلة بحثة، وتحديد المنهجية المناسبة له، وتصميم أداة الدراسة وتحليل وتفسير النتائج، بالإضافة إلى بناء خلفية معرفية متعمقة سوف تكون رافداً مهماً عند إعداد الإطار ولهار

النظري. • . قلة الدراسات العبية التي اهتمت بدراسة الدعم التنظيمي المدرك وعلاقته بالالتزام التنظيمي في المنظمات العربية بشكل عام، وفي المدارس بشكل خاص. حيث أن كل تلك الدراسـات طرقت كل متغير بشكل منفرد أو مع متغيرات آخرى، فلم يعثر الباحث - على حد علمها - على دراسة واحدة تجمع بين الدعم التنظيمي المدرك وعلاقتاه بالالتزام التنظيمي للمعلمين وهذا يكسب هذا البحث أهميته ويكسبه إضافته العلمياة.

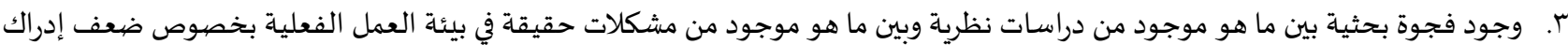

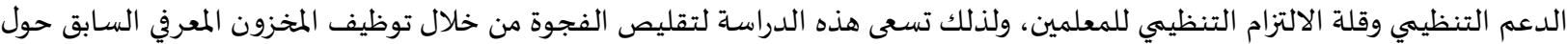
متغيرات الدراسة في علاج مشكلة ضعف الدعم التنظيمي المدك من قبل المعلمين مما انعكس على التزامهم التنظيمي.

\section{طريقة واجراءات الدراسـة:}

هدفت الدراسة الحالية إلى تحديد مستوى الدعم التنظيمي المدرك لدى معلمي مدارس التعليم العام بمحافظة أضمه، وكذلك التعرف على

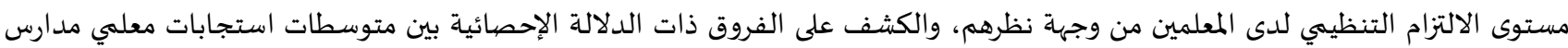
التعليم العام بمحافظة أضم حول تقديرهم لمستوى الدعم التنظيمي المدرك في مدارسهم، ومستوى الالتزام التنظيمي لديهم والتي تعزى لاختلاف مهري

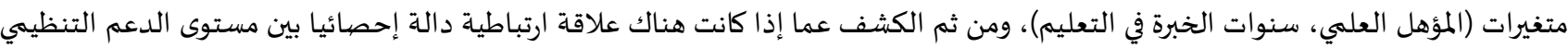

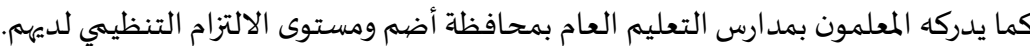
ويتناول هذا الفصل وصف لإجراءات الدراسة الميدانية التي قام بها الباحث لتحقيق أهداف الدراسة، وتتضمن تحديد المنهج المتبع في الدراسة، ومجتمع الدراسـة، وعينة الدراسة، وأداة الدراسة والتحقق من صدقها وثباتها، والمعالجة الإحصائية المستخدمة في تحليل النتائج .

أولاً: منهج الدراسـة:

تحقيقاً لأهد اف الدراسـة ولإجابة على تساؤلاتها، حدد الباحث المنهج الملائم للدراسـة الحالية وهو المنهج الوصفي بشقيه (المستي والارتباطي) ".ومن خلال المنهج الوصفي المستي، قام الباحث بتحديد مستوى الدعم التنظيمي المدرك، ومستوى الالتزام التنظيمي لدى معلمي مدارس التعليم

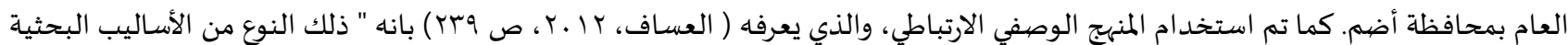


الذي يمكن بواسطته معرفة ما إذا كان هناك ثمة علاقة بين متغيرين أو أكثر، ومن ثم معرفة درجة تلك العلاقة ". ومن خلال المنهج الوصفي الارتباطي

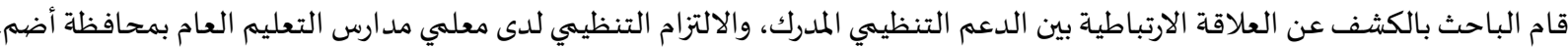
ثانياً: مجتمع الدراسـة: يتمثل مجتمع الدراسة الحالية في معلمي مد ارس التعليم العام بمحافظة أضمى والبالغ عددهم (AVY) معلمأ ، طبقاً لإحصائية مكتب التعليم

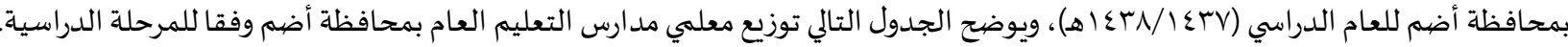
جدول(1) المراسيع أفراد مجتمع الدراسة وفقاً للمرحلة الدراسية

\begin{tabular}{|c|c|c|c|}
\hline النسبة \% & عدد المعلمين & المرحلة الدراسية & م \\
\hline$\% \varepsilon 7$, & $\varepsilon . r$ & الابتدائية & 1 \\
\hline$\%$ \%०,r & $r \cdot \Lambda$ & المتوسطة & $r$ \\
\hline$\% \backslash \curlywedge, \vee$ & $17 r$ & الثانوية & $r$ \\
\hline$\% 1 \ldots$ & AVr & المجمموع & \\
\hline
\end{tabular}

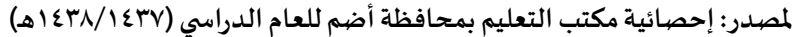

يتضح من الجدول(ا) السابق أن أغلب أفراد مجتمع الدراسة من معلمي مدارس التعليم العام بمحافظة أضم هم معلمي مدارس المرحلة

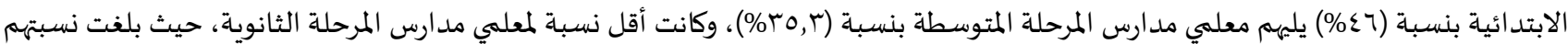

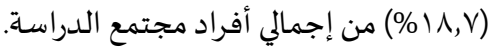
ثالثاً: عينة الدراسـة نظراً لصغر حجم مجتمع الدراسة، فقد تم اختيار عينة الدراسة بطريقة الحصر الشامل لجميع أفراد مجتمع الدراسة، حيث قام الباحث بالتواصل مع معلمي مدارس التعليم العام بمحافظة أضم عبر بريدهم الالكتروني، بهدف توزيع الاستبانة عليهم الكترونيا عن طريق موقع (Google)

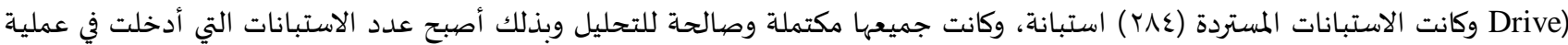

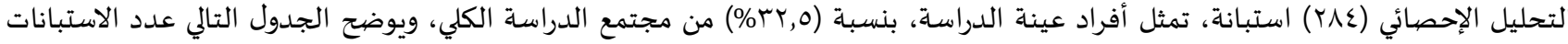

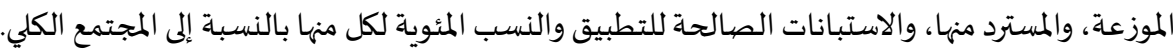

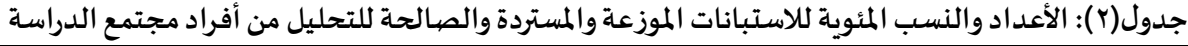

\begin{tabular}{|c|c|c|c|c|c|c|c|}
\hline \multicolumn{2}{|c|}{ الاستبانات الصالحة } & \multicolumn{2}{|c|}{ الاستبانات المستردة } & \multicolumn{2}{|c|}{ الاستبانات الموزعة } & \multicolumn{2}{|c|}{ مجتمع الدراسة } \\
\hline النسبة & العدد & النسبة & العدد & النسبة & العدد & النسبة & لعدد \\
\hline$\%$ Yr, O & $r \Lambda \varepsilon$ & $\% r r, 0$ & 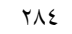 & $\% 1$. & NVr & $\% 1 .$. & NVT \\
\hline
\end{tabular}

خصيائص أفراد عينة الدراسـة:

تم حساب التكرارات والنسب المئوية لأفراد عينة الدراسة وفقاً للمتغيرات (المؤهل العلمي، سنواتهات الخبرة في التعليم)، كما يلي: ا. توزيع أفراد عينة الدراسـة وفقاً للمؤهل العلمي: تم حساب التكرارات والنسب المئوية لأفراد عينة الدراسة وفقاً لمتغير المؤهل العلمي كما تبينه

النتائج بجدول (r) التالي:

جدول (r): التكراروالنسب المئوية لأفراد عينة الدراسة وفقاً لمتغير المؤهل العلمي النيا

\begin{tabular}{|c|c|c|c|}
\hline النسبة\% & التكرار & المؤهل العلمي & م \\
\hline$\% 91,0$ & ri. & بكالوريوس & 1 \\
\hline$\% \wedge, 0$ & $r \varepsilon$ & دراسات عليا & r \\
\hline$\% 1 .$. & 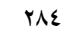 & \multicolumn{2}{|c|}{ المجموع الكلي } \\
\hline
\end{tabular}

يتضع من الجدول(r) السابق أن أغلب أفراد عينة الدراسة من المعلمين مؤهلهم العلمي (بكالوريوس) بنسبة (1,0\%)، أما المعلمين الذين

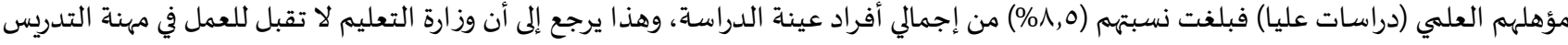

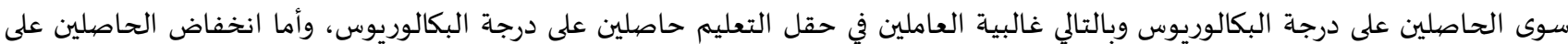
الدراسات العليا فيرجع لعدة أسباب منها أن نسب القبول في الجامعات بالمملكة العربية السعودية في الدراسات العليا بالنسبة للتخصصيات التربوية قليلة جداً، وكذلك أن وزارة التعليم في خططها السنوية لإيفاد المعلمين للحصول على شهادات عليا يكون بأعداد قليلة جداً وفي تخصصيات تربوية

محدودة. 
r. ت توزيع أفراد عينة الدراسة وفقاً لسنوات الخبرة في التعليم:

تم حساب التكرارات والنسب المئوية لأفراد عينة الدراسة وفقاً لمتغير سنوات الخبرة في في التعليم كما تبينه النتائج بجدول (ع) التالي:

جدول(ع): التكراروالنسب المئوية لأفراد عينة الدراسة وفقاً لمتغيرسنوات الخبرة في التعليم

\begin{tabular}{|c|c|c|c|}
\hline النسبة\% & التكرار & سنوات الخبرة في التعليم & م \\
\hline$\% \varepsilon \vee, 0$ & 1ro & أقل من · اسنوات & 1 \\
\hline$\% \varepsilon 1, r$ & $11 \mathrm{~V}$ & من · ا إلى أقل من · r سنة & r \\
\hline$\% 11, r$ & rr & r. r سنة فأكثر & $r$ \\
\hline$\% 1 \ldots$ & 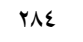 & المجموع الكلي & \\
\hline
\end{tabular}

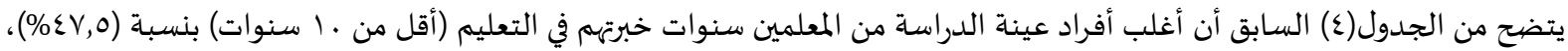

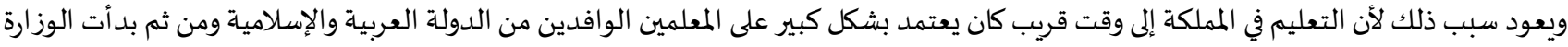

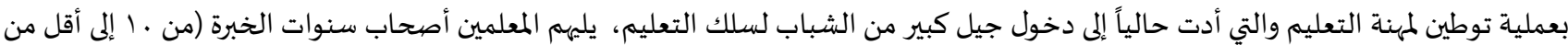

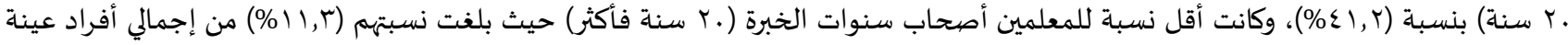

لتحقيق أهداف الدراسة تم الاطلاع على الجانب النظري لمتغيرات الدراسة وإجراء مسح مكتبي للدراسات السابقة التي لها علاقة بموضوع الدابع

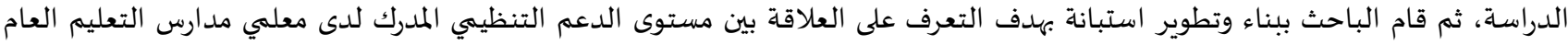
بمحافظة أضم ومستوى الالتزام التنظيمي لديهم. تعد الاستبانة أكثر وسائل الحصول على البيانات من الأفراد استخداماً وانتشاراً، وتعرف الاستبانة بأهها: "أداة ذات أبعاد وبنود وتستخدم

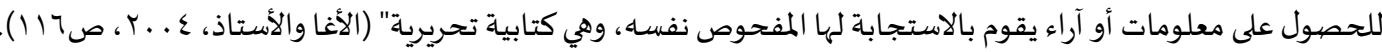

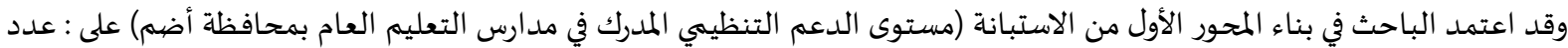
من الدراسات والمقاييس منها مقياس آيزينبيرغر وزملائه (Eisenberger et al., 1986) لقياس الدعم التنظيمي المدرك الذي يقيس درجة إدراك

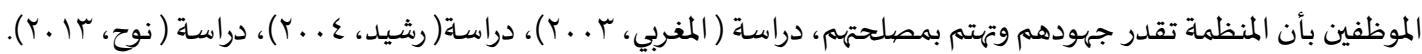

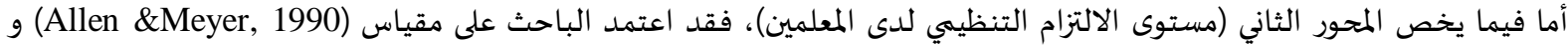

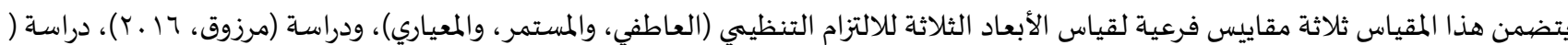

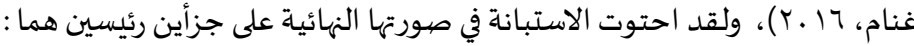

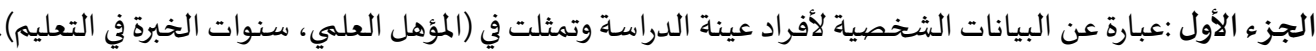

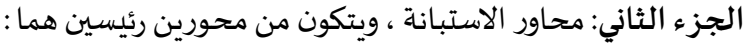

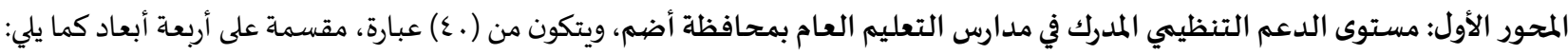
البعد الأول العدالة التنظيمية، وتكون من (r ا ) عبارة مقسمة إلى ثلاثة أبعاد فرعية هي:

عدالة التوزيعات: ويتكون من (0) عبارات. وهي الفقرات من ( إ) إلى (0).

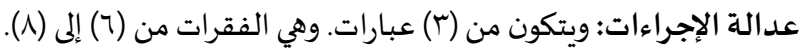

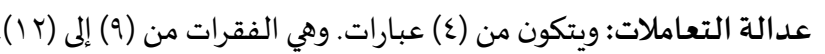

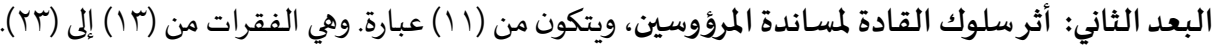

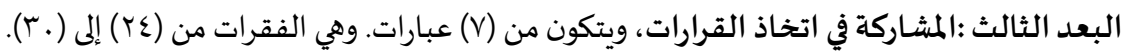

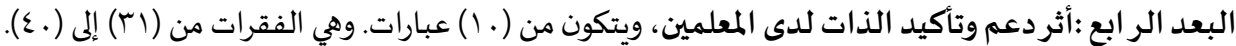

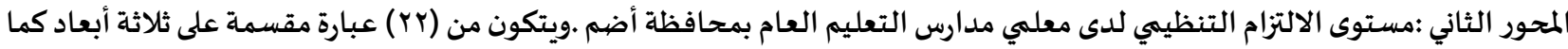

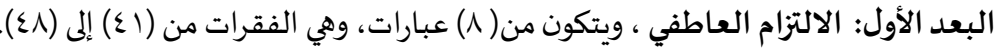

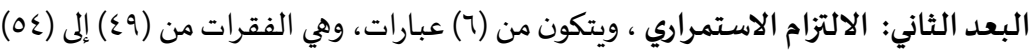

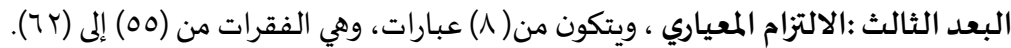




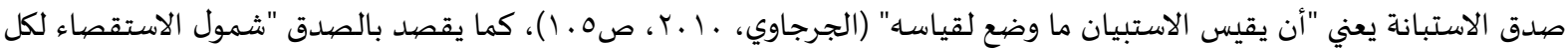
العناصر التي يجب أن تدخل في التحليل من ناحية، ووضوح فقراتها ومفرداتها من ناحية ثانية، بحيث تكون مفهومة لكل من يستخدمها" (عبيدات

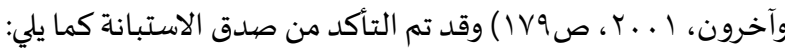

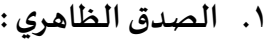

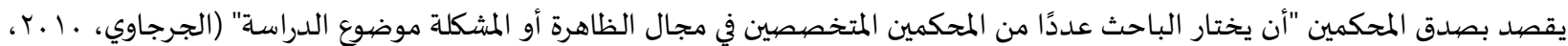

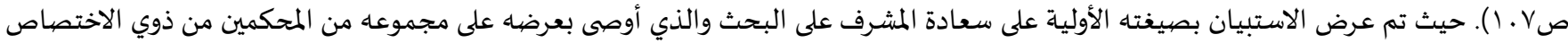

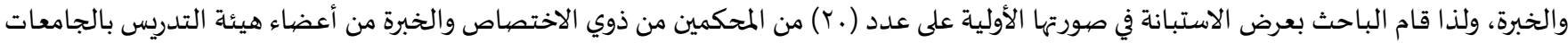

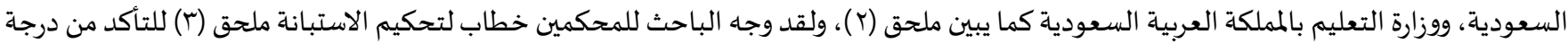

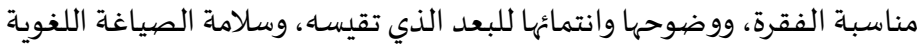

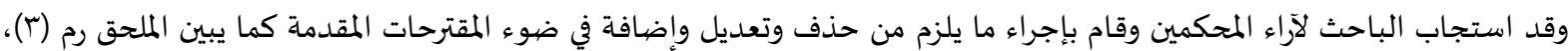

وبذلك خرجت الاستبانة في صورتها النهائية كما يبين الملحق (ع).

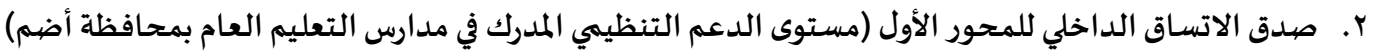

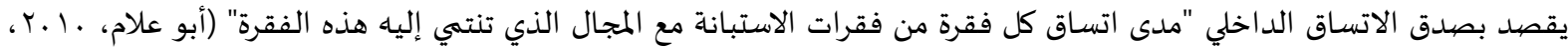

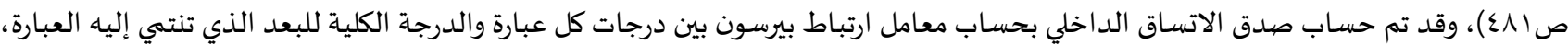

كما يوضحها الجدول التالي:

جدول(0): معاملات ارتباط بيرسون بين درجات كل عبارة والدرجة الكلية للبعد الذي تنتمي إليه من المحور الأول (مستوى الدعم التنظيمي المدرك في مدارس

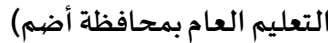

\begin{tabular}{|c|c|c|c|c|c|c|c|c|c|c|c|}
\hline \multirow{2}{*}{\multicolumn{2}{|c|}{ 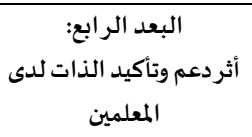 }} & \multirow{2}{*}{\multicolumn{2}{|c|}{ 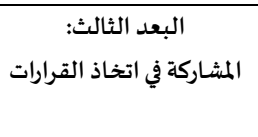 }} & \multirow{2}{*}{\multicolumn{2}{|c|}{$\begin{array}{c}\text { أثرسلوك القادة لمساندة الثماني: } \\
\text { المرؤوسين } \\
\end{array}$}} & \multicolumn{6}{|c|}{ 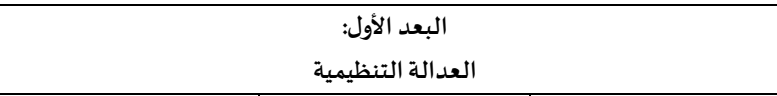 } \\
\hline & & & & & & \multicolumn{2}{|c|}{ عدالة التعاملات } & \multicolumn{2}{|c|}{ عدالة الإجراءات } & \multicolumn{2}{|c|}{ عدالة التوزيعات } \\
\hline معامل الارتباط & $\hat{n}$ & معامل الارتباط & م & معامل الارتباط & م & معامل الارتباط & م م & معامل الارتباط & م م & معامل الارتباط & م \\
\hline **.,VV. & $r$ & **., VqV V & $r \varepsilon$ & **., $\vee \wedge \wedge 1$ & ir & **.,AYI & 9 & **.,AYY & 7 & $* *, T \varepsilon r$ & 1 \\
\hline$* *, V 79$ & $r r$ & $* * ., \wedge .7$ & ro & **.,人ाr & $1 \varepsilon$ & $*^{* *}, \wedge \vee \wedge$ & 1. & $* *, \wedge 71$ & $v$ & $* *, V \backslash \varepsilon$ & $r$ \\
\hline **.,VY. & $r r$ & 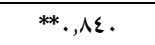 & r & ${ }^{* *} ., \mathrm{VAr}$ & 10 & **., ^乏ๆ & 11 & $* *, V \Sigma Y$ & 1 & **.,VAY & $r$ \\
\hline **., $\vee १ \varepsilon$ & $r \varepsilon$ & **., $\vee १ १$ & $r V$ & **., $\vee १ ९$ & 17 & $* *, \Lambda . r$ & ir & & & $* * .790$ & $\varepsilon$ \\
\hline$*_{*}^{*}, 0<0$ & ro & $*^{* *}, \wedge \mathrm{\wedge r}$ & YM & $*^{* *}, \Delta Y I$ & iv & & & & & $* *, 710$ & 0 \\
\hline **., TAr & $m$ & **.,Ar. & rq & $* * ., \wedge .1$ & 11 & & & & & & \\
\hline **., $77 \varepsilon$ & $r v$ & **.,AYI & $r$. & **.,Arr & 19 & & & & & & \\
\hline$*^{* *}, 0 \leqslant V$ & $r \Lambda$ & & & **.,AYV & $r$. & & & & & & \\
\hline$* * ., 07 r$ & rq & & & **., ^乏V & YI & & & & & & \\
\hline$* *$, V7o & $\varepsilon$. & & & $* * ., \wedge \Sigma V$ & Yr & & & & & & \\
\hline & & & & **.,人ro & $r r$ & & & & & & \\
\hline
\end{tabular}

* دال إحصائيا عند مستوى دلالة ا . ,.

يتبين من الجدول(0) السابق أن معاملات ارتباط العبارات بالدرجة الكلية للبعد الذي تنتمي إليه العبارة جميعها دالة إحصائياً عند مستوى

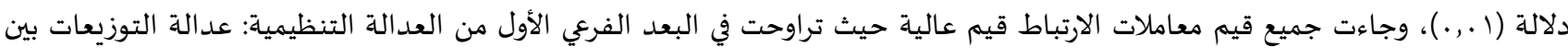

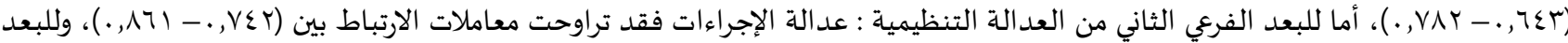

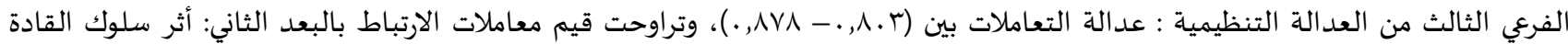

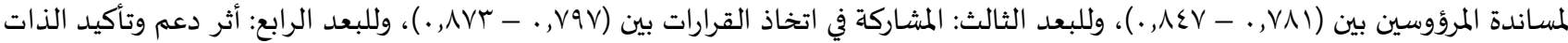

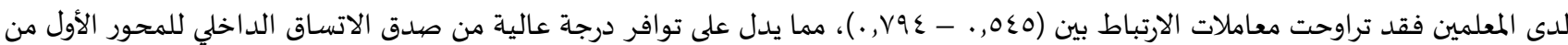
الاستبانة (مستوى الدعم التنظيمي المدرك في مدارس التعليم العام بمحافظة أضمى) .

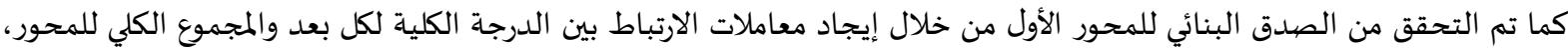
ويوضح نتائجها الجدول التالي: 
جدول(7): معاملات الارتباط بين درجات كل بعدوالدرجة الكلية للمحور الأول (مستوى الدعم التنظيمي المدرك في مدارس التعليم العام بمحافظة أضمم)

\begin{tabular}{|c|c|c|}
\hline معامل الارتباط & 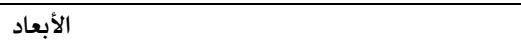 & \\
\hline$* * ., 9 \cdot 1$ & البعد الأول: العدالة التنظيمية & 1 \\
\hline **., qr & البعد الثاني: أثر سلوك القادة لمساندة المرؤوسين & r \\
\hline$*^{* *}, 9 T \mathrm{~T}$ & البعد الثالث: المشاركة في اتخاذ القرارات & $r$ \\
\hline **.,人৭r & البعد الرابع: أثر دعم وتأكيد الذات لدى المعلمين & $\varepsilon$ \\
\hline
\end{tabular}

* * * دال إحصائياً عند مستوى دلالة (1 . , . ) أبعد الرابع:

يتبين من جدول(7) السابق أنّ قيم معاملات الارتباط للأبعاد الأربعة التي يتكون منها المحور الأول والمجموع الكلي للمحور جاءت قيم مرتفعة

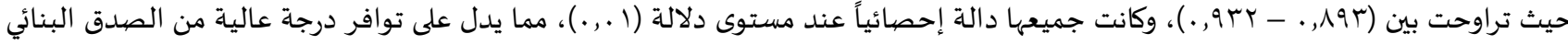

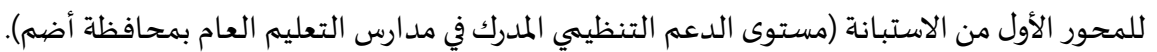

r. صدل الاتساق الداخلي للمحور الثاني (مستوى الالتزام التنظيمي لدى معلمي مدارس التعليم العام بمحافظة أضمى)

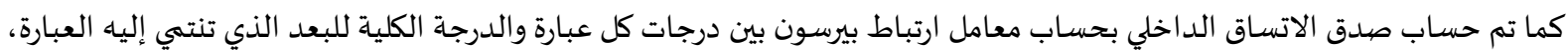

كما يوضحها الجدول التالي:

جدول(V): معاملات ارتباط بيرسون بين درجات كل عبارة والدرجة الكلية للبعد الذي تنتمي إليه من المحور الثاني (مستوى الالتزام التنظيمي لدى معلمي مدارس التعليم العام بمحافظة أضهم)

\begin{tabular}{|c|c|c|c|c|c|}
\hline \multicolumn{2}{|c|}{ الالتزام المعياري } & \multicolumn{2}{|c|}{ الالتزام الاستمراري الثاني } & \multicolumn{2}{|c|}{ 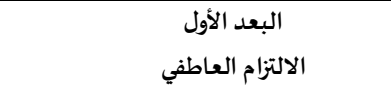 } \\
\hline معامل الارتباط & a & معامل الارتباط & م & معامل الارتباط & م \\
\hline **.,VTr & 00 & ${ }^{* *} \cdot, \wedge \cdot \wedge$ & $\varepsilon q$ & **., จา & \&l \\
\hline${ }^{* *} ., 7 \leqslant V$ & 07 & **.,人 १ & 0. & 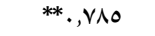 & $\varepsilon r$ \\
\hline **.,VרY & or & **.,人7। & 01 & ${ }^{* *} \cdot, \wedge 19$ & $\varepsilon r$ \\
\hline${ }^{* *} ., V \varepsilon 7$ & 01 & $*_{*}{ }_{0}, \varepsilon r$. & or & "**, & $\varepsilon \varepsilon$ \\
\hline${ }^{* *} ., \mathrm{V} \vee \varepsilon$ & 09 & **., А Ү० & or & **., ^৭. & \&o \\
\hline 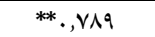 & 7. & **.,070 & of & ${ }^{* * *}, \wedge \wedge \wedge$ & $\left.\sum\right\rceil$ \\
\hline$* *, 700$ & 71 & & & **., V५. & \&v \\
\hline${ }^{* * *}, \mathrm{~V} V \mathrm{r}$ & $T r$ & & & ${ }^{* *},, \wedge \backslash \wedge$ & ह1 \\
\hline
\end{tabular}

** دال إحصيائيا عند مستوى دلالة ا .,.

يتبين من الجدول(V) السابق أن معاملات ارتباط العبارات بالدرجة الكلية للبعد الذي تنتمي إليه العبارة جميعها دالة إحصائياً عند مستوى

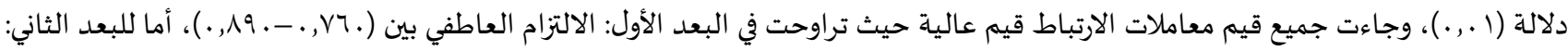

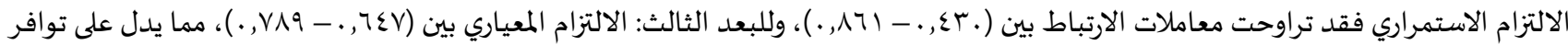

درجة عالية من صدق الاتساق الد اخلي للمحور الثاني (مستوى الالتزام التنظيمي لدى معلمي مدارس التعليم العام بمحافظة أضمى).

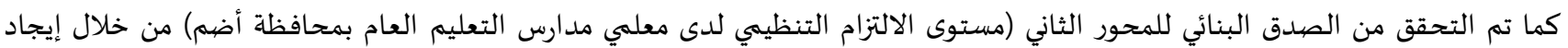
معاملات الارتباط بين الدرجة الكلية لكل بعد والمجموع الكلي للمحور، ويوضح نتائجها الجدول التمبل التالي:

جدول(^): معاملات الارتباط بين درجات كل بعدوالدرجة الكلية للمحور الثاني (مستوى الالتزام التنظيمي لدى معلمي مدارس التعليم العام بمحافظة أضم)

\begin{tabular}{|c|c|c|}
\hline معامل الارتباط & الأبعاد & م \\
\hline$*^{* *} ., 9 Y \varepsilon$ & البعد الأول: الالتزام العاطفي & 1 \\
\hline **., ^৭. & البعد الثاني: الالتزام الاستمراري & r \\
\hline **., $9 \pi \mathrm{r}$ & البعد الثالث: الالتزام المعياري & r \\
\hline
\end{tabular}

(** دال إحصائياً عند مستوى دلالة (1 . . . )

يتبين من جدول(^) السابق أنّ قيم معاملات الارتباط للأبعاد الثلاث التي يتكون منها المحور الثاني (مستوى الالتزام التنظيمي لدى معلمي

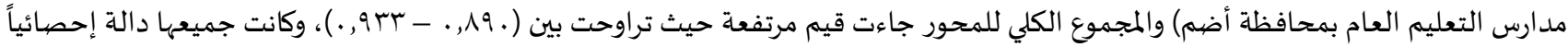
عند مستوى دلالة (ا . ..)، مما يدل على توافر درجة عالية من الصددق البنائي للمحور الثاني (مستوى الالتزام التنظيمي لدى معلمي مدارس التعليم العام بمحافظة أضم). 
ثبات أداة البحث:

يقصد بثبات الاستبانة هو أن يعطي الاستبيان نفس النتائج إذا أعيد تطبيقه عدة مرات متتالية، ويقصد باه أيضاً إلى أي درجة يعطي المقياس قراءات متقاربة عند كل مرة يستخدم فيها، أو ما هي درجة اتساقه وانسجامه واستمراريته عند تكرار استخد امه في أوقات مختلفة (الجرجاوي،

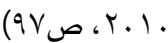

وقد تم التأكد من ثبات الاستبانة من خلال حساب ثبات الاتساق الداخلي للعبارات باستخد ام معامل ألفا كرونباخ. يتضح من جدول(9) أن قيم معاملات الثبات لأبعاد المحور الأول (مستوى الدعم التنظيمي المدرك في مدارس التعليم العام بمحافظة أضم) جاءت قيم عالية حيث تراوحت قيم

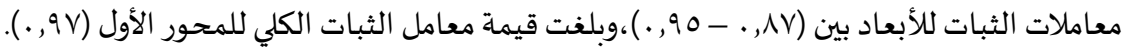
كما جاءت قيم معاملات الثبات لأبعاد المحور الثاني (مستوى الالتزام التنظيمي لدى معلمي مدارس التعليم العام بمحافظة أضم) بقيم

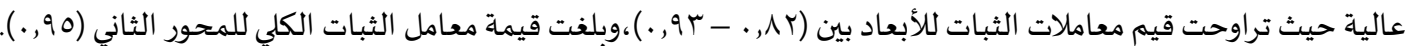
جدول(9): معاملات ثبات ألفا كرونباخ للأبعاد ومحوري الاستبانة

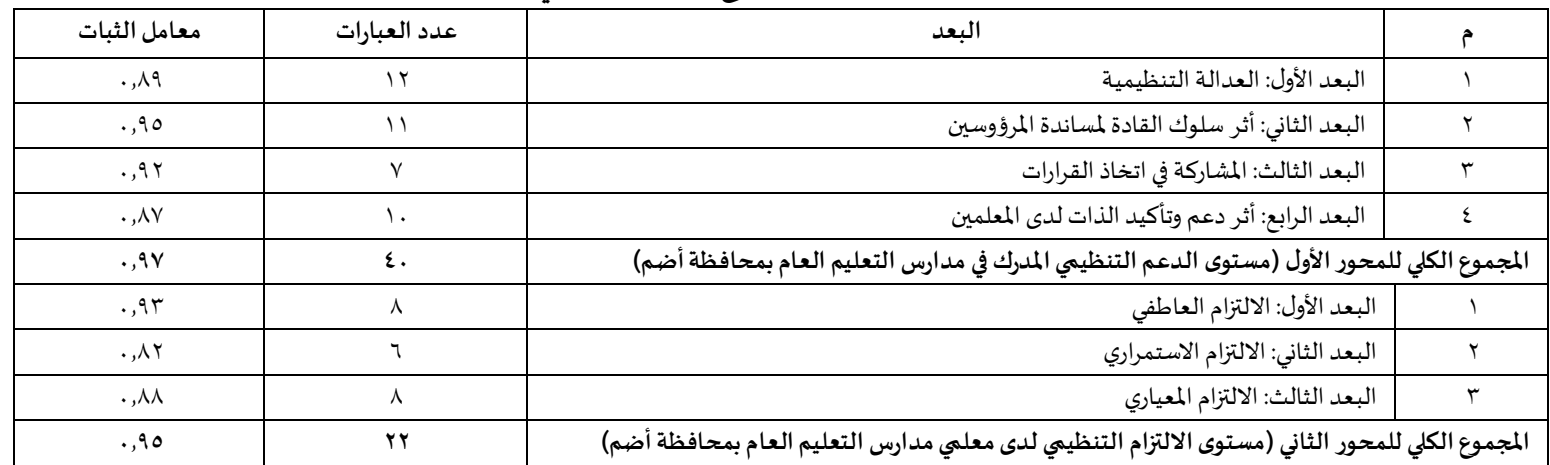

وبذلك تكون الاستبانة في صورتها النهائية كما هي في الملحق (ع) قابلة للتوزيع. ويكون الباحث قد تأكد من صدق وثبات الاستبانة مما يجعلـه

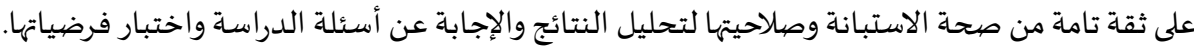

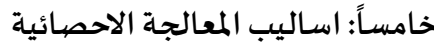
بناءً على طبيعة الدراسة والأهداف التي سعت إلى تحقيقها، تمّ تحليل البيانات باستخدام برنامج الحزمة الإحصائية للعلوم الإجتماعية (SPSS) ا. التكرارات والنسب المئوية: للتعرف على خصائص أفراد عينة الدراسة وفقا للبيانات الشخصية. r. المتوسطات الحسابية والانحر افات المعيارية: لحساب متوسطات عبارات محوري الاستبانة وكذلك الدرجات الدات الكلية والدرجات الدرات الفرعية لأبعادهما بناء على استجابات أفراد عينة الدراسة. r. معامل ارتباط بيرسون: لحسـاب الاتساق الداخلي وكذلك لتحديد العلاقة بين مستوى الدعم التنظيمي المدرك ومستوى الالتزام التنظيمي لدى الدي معلمي مد ارس التعليم العام بمحافظة أضيم. ع. معامل ألفا كرونباخ: لحساب الثبات لعبارات الاستبانة.

ه. معادلة المدى: وذلك لوصف المتوسط الحسابي للاستجابات على كل عبارة وبعد، على النحو التالي:

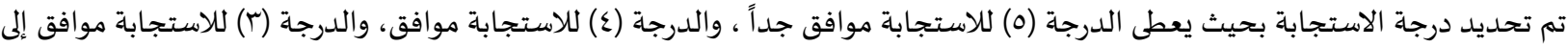

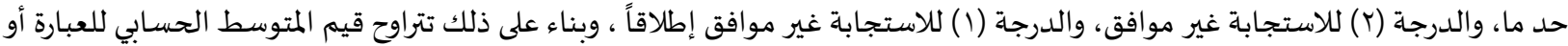

من ا إلى أقل من •^ر, ا تمثل درجة استجابة (غير موافق إطلاقاً).

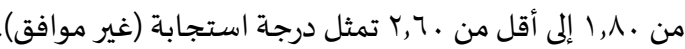
من • • r, إلى أقل من • ع, r تمثل درجة استجابة (موافق إلى حد ما).

البعد:

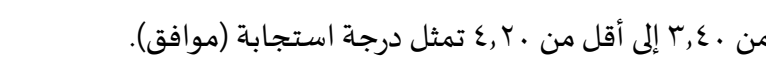

$$
\begin{aligned}
& \text { من ، r, ع إلى ه تمثل درجة استجابة (موافق جدا). }
\end{aligned}
$$

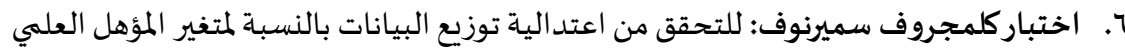
V. اختبارليفين للتجانس: للتحقق من التجانس في توزيع استجابات أفراد عينة اعتئة البحث على جميع أبعاد الاستبانة بالنسبة لمتغير (المؤهل العلمي). 
^. الاختبار اللامعلمي مان ويتني للتعرف على دلالة ما قد يوجد من فروق بين المتوسّطات الحسابية لاستجابات أفراد عينة الدراسة وفقاً لمتغير

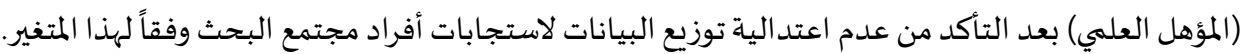
9 . تحليل التباين أحادي الاتجاه (One-way ANOVA) للتعرف على دلالة ما قد يوجد من فروق بين المتوسّطات الحسابية لاستجابات أفراد عينة الدراسة وفقاً لمتغير (سنوات الخبرة في التعليم).

نتائج الدراسـة ومناقشتها: هدفت الدراسة الحالية إلى تحديد مستوى الدعم التنظيمي المدرك لدى معلمي مدارس التعليم العام بمحافظة أضم، وكذلك التعرف على

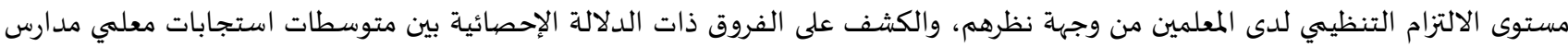
التعليم العام بمحافظة أضهم حول تقديرهم لمستوى الدعم التنظيمي المدرك في مدارسهم ، ومستوى الاستغراق لوظيفي لدهيهم والتي تعزى لاختلاف متهم متغيرات (المؤهل العلمي، سنوات الخبرة في التعليم)، ومن ثم الكشف عما إذا كانت هناك علاقة ارتباطية دالة إحصائيا بين مستوى الدعم التنظيمي

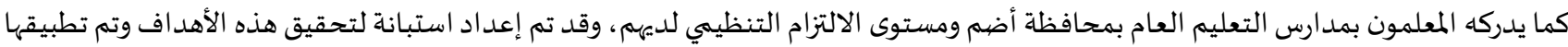

على أفراد عينة الدراسة من معلمي مدارس التعليم العام بمحافظة أضمه، وكانت النتائج على النحو التالي:

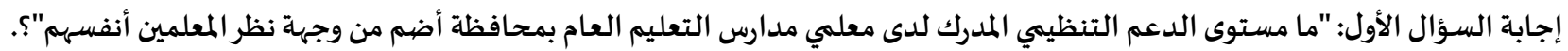
وللإجابة على هذا السؤال، فقد تم حساب المتوسط الحسابي والانحراف المعياري لأبعاد المحور الأول من الاستبانة (مستوى الدعم التنظيمي

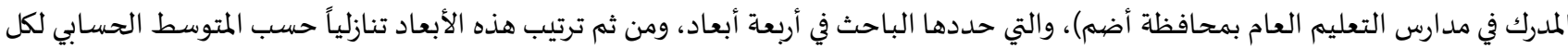
بعد، ويبين ذلك الجدول ( • () التالي:

جدول( • (): المتوسطات الحسابية والانحر افات المعيارية لأبعاد المحور الأول من الاستبانة (مستوى الدعم التنظيمي المدرك في مدارس التعليم العام بمحافظة أضهم)، مرتبة تنازلياً

\begin{tabular}{|c|c|c|c|c|c|}
\hline درجة المو افقة & ترتيب البعد & الانحراف المعياري & المتوسط الحسابي & البعد البعد & 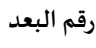 \\
\hline 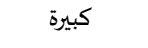 & 1 & $\cdot, 707$ & $\varepsilon, .1$ & أثر دعم وتأكيد الذات لدى المعلمين & $\varepsilon$ \\
\hline 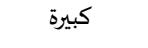 & r & $\cdot$, A.r & $r, 99$ & أثر سلوك القادة لمساندة الممؤوسين & r \\
\hline 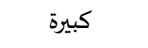 & $r$ & $\cdot, 110$ & $r, \wedge 7$ & المشاركة في اتخاذ القرارات & $r$ \\
\hline 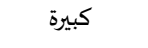 & $\varepsilon$ & . & $r, \lambda r$ & العدالة التنظيمية & 1 \\
\hline 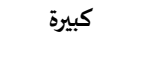 & --- & •,741 & $r, q r$ & \multicolumn{2}{|c|}{ المجموع الكلي (مستوى الدعم التنظيمي المدرك في مدارس التعليم } \\
\hline
\end{tabular}

ويعزو الباحث حصول مستوى الدعم التنظيمي المدرك في مدارس التعليم العام بمحافظة أضهم على درجة (كبيرة) من وجهة نظر المعلمين إلى

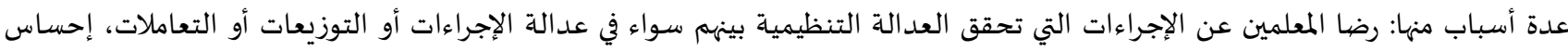

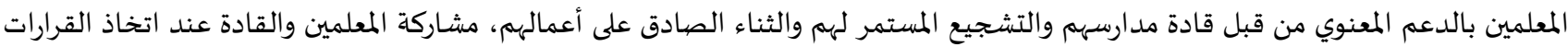
الإدارياة، سعي إدارات المدارس والتعليم إلى حل مشاكل المعلمين وإزالة جميع العقبات وتذليل جميع الصعوبات التي تواجههم، شعور المعلمين برغبة

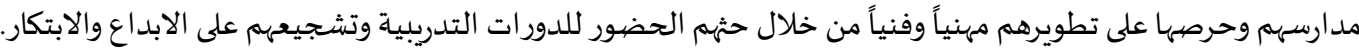
وتتفق هذه النتيجة مع نتيجة دراسة ( المغربي، ب . .ب) والتي أظهرت وجود دعم تنظيمي فعال تقدماه المؤسسة للعاملين بها يؤثر على مستوى

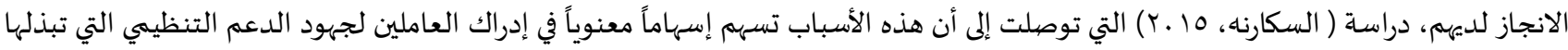
المؤسسات تجاههم، ودراسة ( الصباغ، و . .ب) التي ذكرت بأن هناك درجة مرتفعة إلى حد ما من الدعم التنظيمي بالمستشفيات، دراسة ( الحراحشها

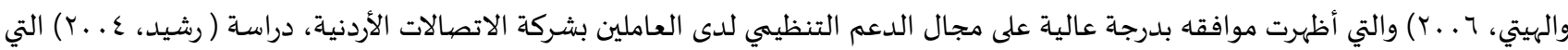
أشرات لوجود علاقة إيجابية بين الدعم التنظيمي والولاء العاطفي فالأشخاص الذين يشعرون أن المنظمة تقدرهم وتدعمهمه عبروا عن مشاعر

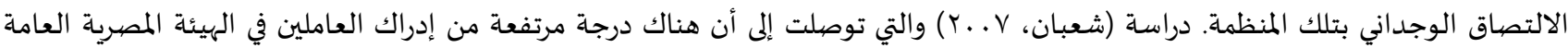
للبترول للدعم التنظيمي. بينما تختلف مع نتيجة دراسة ( السلوم والعضايلة، با ـ ب) والتي كشفت نتائجها أن إدراك الدعم التنظيمي لدى أعضاء الهيئة التدريسية

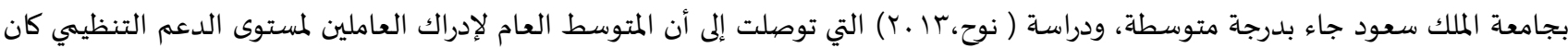
بدرجة متوسطة، ودراسة (عواد، V. . . والتي تبين بأن إدراك العاملين بقطاع الصناعات المعدنية للدعم التنظيمي جاء بدرجة متوسطة، دراسة

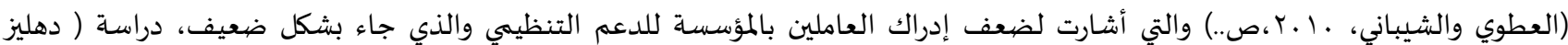




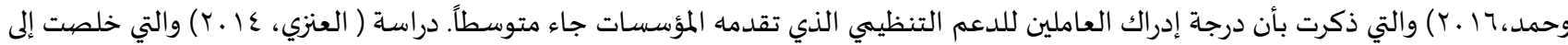

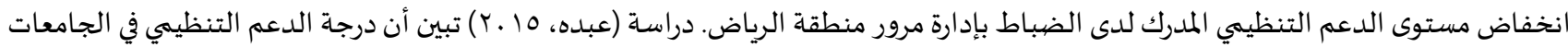

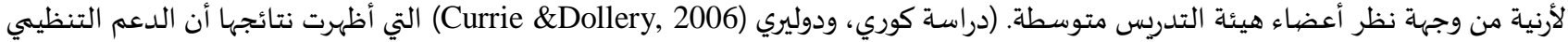

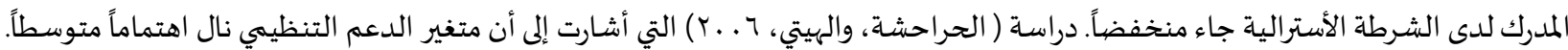

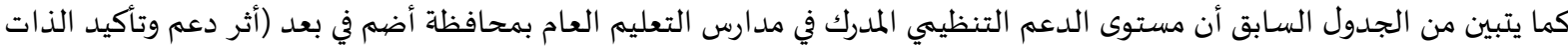

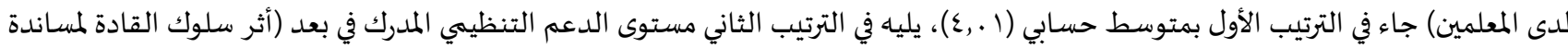

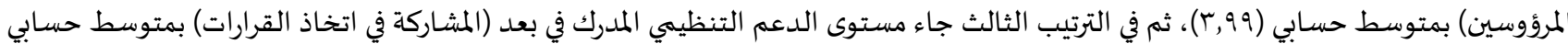

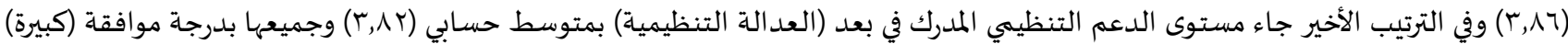
من وجهة نظر المعلمين. ويمكن تفسير حصول مستوى الدعم التنظيمي المدرك في مدارس التعليم العام بمحافظة أضم في بعد (أثر دعم وتأكيد الذات لدى المعلمين)

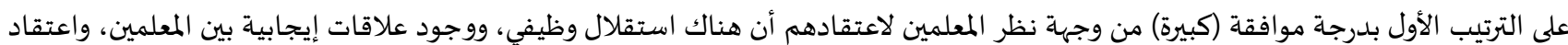

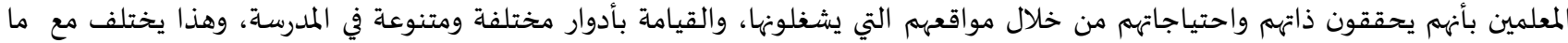

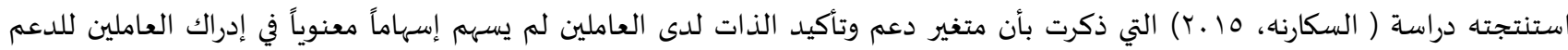

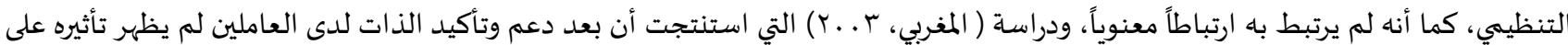
إدراك العاملين للدعم التنظيمي.

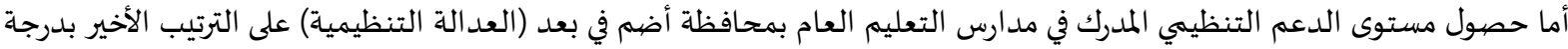
موافقة (كبيرة) ربما يرجع إلى حاجة المعلمين للمشاركة بشكل أكبر في القرارات، ويتطلعون لتحقيق مطالهم الشخصيية، ويتمنون أن يتخذ قائدي

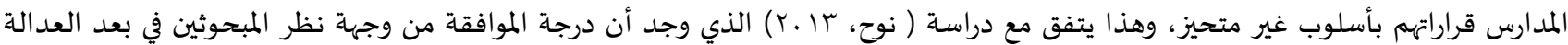

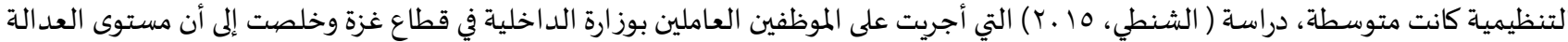

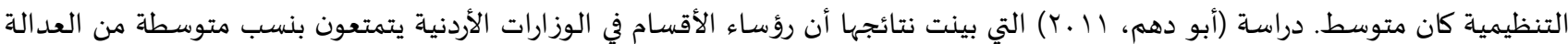
التنظيمية. دراسة (الفضلي، والعنزي، Y...r) التي كشفت نتائجها عن انخفاض إحساس العاملين في الأجهزة الحكومية بدولة الكويت بالعدالة

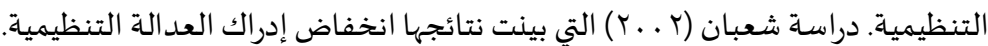

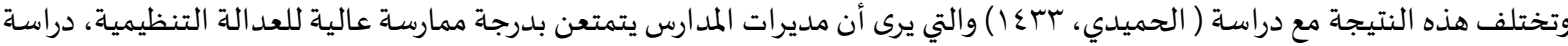

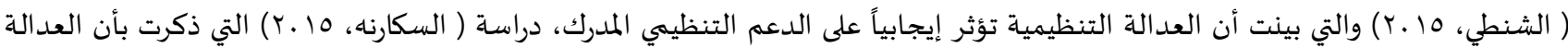

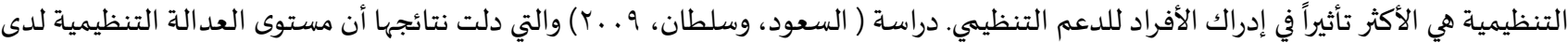
رؤساء الأقسام الأكاديمية كانت مرتفعة. ولمزيد من التفصيل، قام الباحث بحساب المتوسطات الحسابية والانحرافات المعيارية لمستوى الدعم التنظيمي المدرك في مدارس التعليم

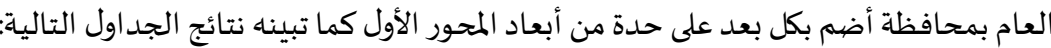

البعد الأول: مستوى العدالة التنظيمية كأحد أبعاد الدعم التنظيمي المدرك في مدارس المدائ التعليم العام بمحافظة أضهم من وجهة نظر المعلمين:

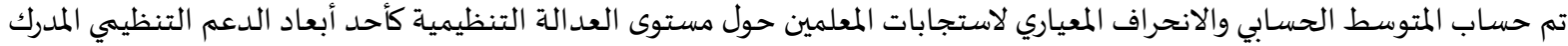

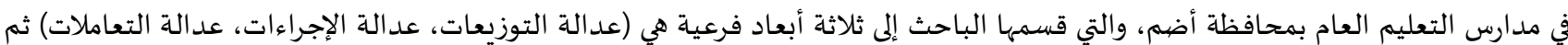

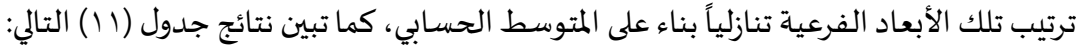
جدول (1):المتوسطات الحسابية والانحر افات المعيارية لاستجابات المعلمين حول مستوى العدالة التنظيمية كأحد أبعاد الدعم التنظيمي المدرك في مدارس التعليم العام بمحافظة أضهم ، مرتبة تنازلياً

\begin{tabular}{|c|c|c|c|c|c|}
\hline درجة المو افقة & ترتيب البعد & الانحراف المعياري & المتوسط الحسابي & البعد & رقم البعد \\
\hline كبيرة & 1 & תוז, & $r, \Lambda V$ & عدالة التعاملات & $r$ \\
\hline كبيرة كبرة & $r$ & $\cdot, \lambda \cdot r$ & $r, \lambda r$ & عدالة الإجراءات & $r$ \\
\hline كبيرة & $r$ &.,$V r \varepsilon$ & $r, v \Lambda$ & عدالة التوزيعات & 1 \\
\hline كبيرة كبرة & --- & 列 & $r, \lambda r$ & \multicolumn{2}{|c|}{ 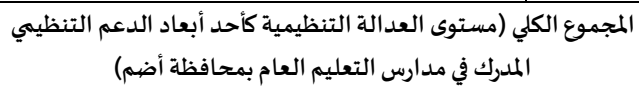 } \\
\hline
\end{tabular}

يتبين من جدول (1 ) السابق أن مستوى العدالة التنظيمية كأحد أبعاد الدعم التنظيمي المدرك في مدارس التعليم العام بمحافظة أضم التما

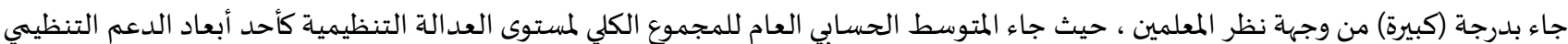




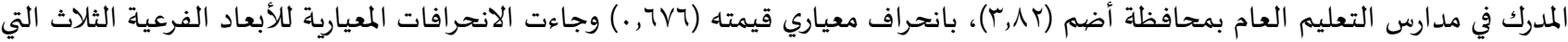

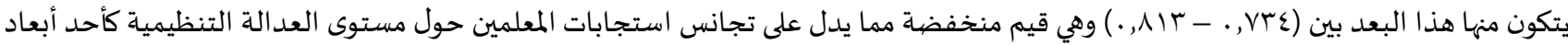

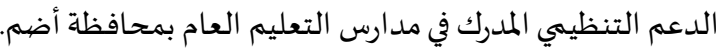

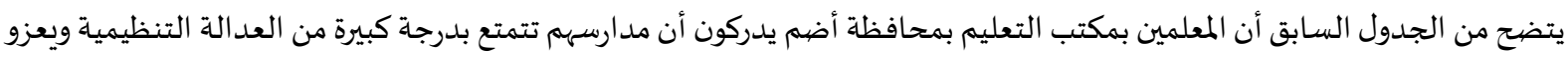
الباحث ذلك إلى أن المعلمين يشاركون قادة مدارسهم في اتخاذ القرارات، يقَّيم أدائهم الوظيفي بشكل عادل، تكليف المعلمين بالأعمال التي تتناسب مع

مؤهلاتهم وقدراتهم، تناسب الراتب الشهري مع حجم المكلفين بها. وتتفق نتائج هذه الدراسة مع دراسة ( الحميدي، بآعاهـ) التي توصلت نتائجها إلى أن ممارسة مديرات المدارس الثانوياة بمحافظة جدة للعدالة التنظيمية جاء بدرجة عالية، دراسة ( شعبان، r . . التي بينت نتائجها وجود علاقة إيجابية دالة بين المشاركة في اتخاذ القرار وادراك العدالة التنظيمية.

تختلف مع نتائج هذه الدراسة دراسة ( الدوسري، 17 ـ†) والتي أظهرت نتائجها أن مستوى إدراك أفراد عينة الدراسة من العاملين بشرطة

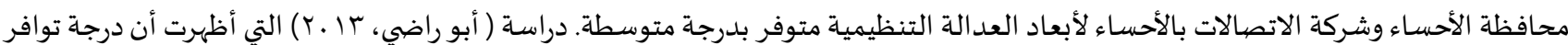
قيم العدالة التنظيمية لدى مديري المدارس الخاصة في محافظة عمّان من وجهة نظر المعلمين كانت متوسطة.

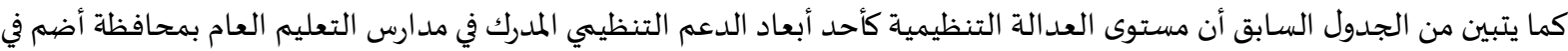
بعد (عدالة التعاملات) جاء في الترتيب الأول بمتوسط حسابي (r,^V)، يلياه في الترتيب الثاني مستوى العدالة التنظيمية في بعد (عدالة الإجراءات)

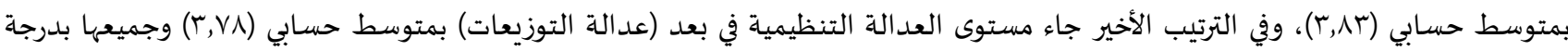
موافقة (كبيرة) من وجهة نظر المعلمين. ولمزيد من التفصيل، قام الباحث بحساب المتوسطات الحسابية والانحرافات المعيارية لمستوى العدالة التنظيمية كأحد أبعاد الدعم

التنظيمي المدرك في مدارس التعليم العام بمحافظة أضمى بكل بعد فرعي على حدة من الأبعاد الفرعية للبعد الأول كما تبينها نتائج الجداول التالية البعد الفرعي الأول: مستوى عدالة التوزيعات كأحد أبعاد العدالة التنظيمية في مدارس التعليم العام بمحافظة أضيم:

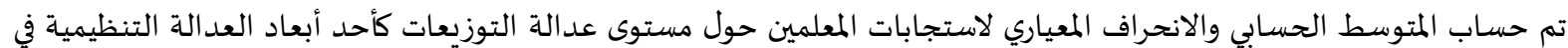
مدارس التعليم العام بمحافظة أضم ثم ترتيب تلك الاستجابات تنازلياً بناء على المتوسط الحسابي، يتبين من جدول (r ( ) أن مستوى عدالة التوزيعات

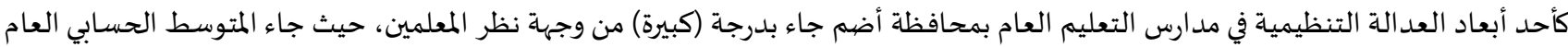

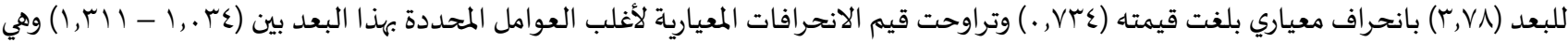
قيم مرتفعة مما يدل على تباين استجابات المعلمين حول مدى توافر العوامل الدالة على مستوى عدالة التوزيعات كأحد أبعاد العدالة التنظيمية في

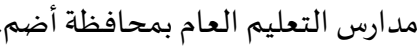

جدول (r ا): المتوسطات الحسابية والانحر افات المعيارية لاستجابات المعلمين حول مستوى عدالة التوزيعات كأحد أبعاد العدالة التنظيمية في مدارس التعليم العام بمحافظة أضهم ، مرتبة تنازلياً

\begin{tabular}{|c|c|c|c|c|c|}
\hline المو افقة درجة & ترتيب & المعياري & الحسابي & 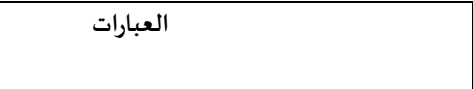 & رقم العبارة \\
\hline كبيرة & 1 & $\cdot, 177$ & $\varepsilon, 1$. & تكلفني إدارة المدرسة بعمل يتناسب مع قدراتي & r \\
\hline كبيرة & r & $\cdot, \wedge \varepsilon 1$ & $\varepsilon, .0$ & ت تناسب ساعات العمل مع ظروفي الخاصة & 1 \\
\hline كبيرة & $r$ & $1, . r \varepsilon$ & $r, 10$ & يقيم أدائي الوظيفي في المدرسة بشكل عادل & $\varepsilon$ \\
\hline 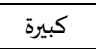 & $\varepsilon$ & $1,1 \pi r$ & $r, \lambda$. & يتناسب الراتب الشهري مع الجهود المبذولة في العمل & 0 \\
\hline متوسطة & 0 & $1, r 11$ & $r, . \wedge$ & يقابل الجهود التي أبذلها في العمل مكافآت مجزية & $r$ \\
\hline 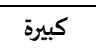 & --- & . $v r \varepsilon$ & $r, v \wedge$ & \multicolumn{2}{|c|}{ لمجموع الكلي للبعد الفرعي الأول : عدالة التوزيعات } \\
\hline
\end{tabular}

ويلاحظ الباحث أن هناك موافقة بين المعلمين على فقرات هذا المجال، وأن المعلمين يعتقدون بوجود عدالة في التوزيع وهذا يدل على كفاءة

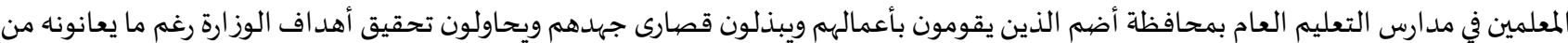
زيادة في الأعباء الوظيفية وزيادة في ساعات العمل، بالرغم من قلة الحوافز الممنوحة لهم مقابل الجهود التي يبذلونها.

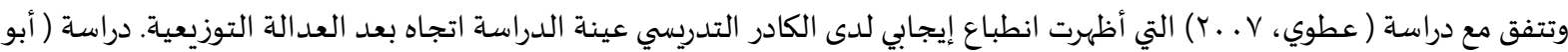
جاسر، ـا.ب) والتي بينت أن العاملين في الوزارات الفلسطينية يشعرون بالعدالة التوزيعية والتي جاءت في المرتبة الأولى ثم الاحساس بعدالة الإجراءات ثم عدالة التعاملات. دراسة (Loi, Hangyue, \&Foley, 2006) والتي من أهم نتائجها أن عدالة التوزيعات ساهمت في تطوير الدعم التنظيمي المدرك لدى العاملين. 


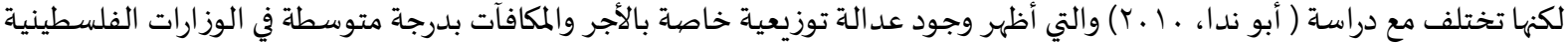

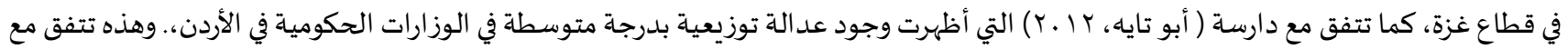

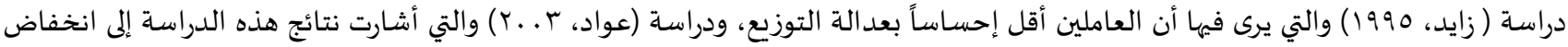
إحساس المعلمين بعد الة التوزيع.

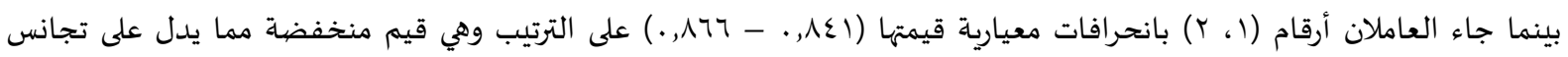
استجابات المعلمين حول مدى توافر هاذين العاملين

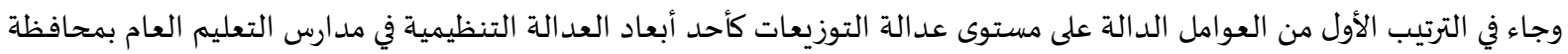

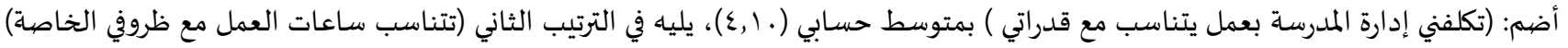

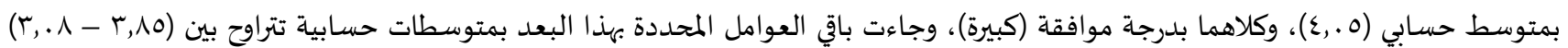

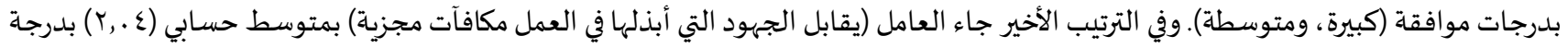

موافقة (متوسطة). البعد الفرعي الثاني: مستوى عدالة الإجراءات كأحد أبعاد العدالة التنظيمية في مدارس التعليم العام بمحافظة أضهم: التباديا

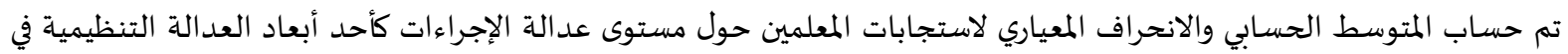

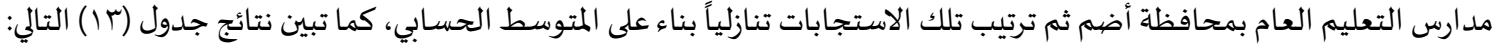
جدول (rا) : المتوسطات الحسابية والانحر افات المعيارية لاستجابات المعلمين حول مستوى عدالة الإجراءات كأحد أبعاد العدالة التنظيمية في مدارس التعليم العام بمحافظة أضمى ، مرتبة تنازلياً

\begin{tabular}{|c|c|c|c|c|c|}
\hline درجة المو افقة & ترتيب العبارة & الانحراف المعياري & المتوسط الحسابي & 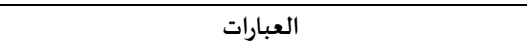 & 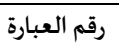 \\
\hline كبيرة & 1 &., 974 & $r, q r$ & أستطيع الاعتراض على القرارات التي تصدر ضدي & $\Lambda$ \\
\hline كبيرة & r & $.9 \mathrm{VV}$ & r,qr & تطبق إدارة المدرسة اللوائح والتعليمات بطريقة عادلة & 7 \\
\hline 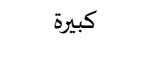 & r & $1, \cdot r 1$ & $r, 70$ & تتخذ أي قرارات إدارية المعلومارة المدات الكاملة والدقيقة قبل أن & $\mathrm{v}$ \\
\hline 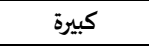 & --- & $\cdot$, A.r & $r, \Lambda T$ & لـد الفرعي الثاني : عدالة الإجراءات & المجموع الكلي \\
\hline
\end{tabular}

يتبين من جدول(r) السابق أن مستوى عدالة الإجراءات كأحد أبعاد العدالة التنظيمية في مدارس التعليم العام بمحافظة أضمر جاء (باء

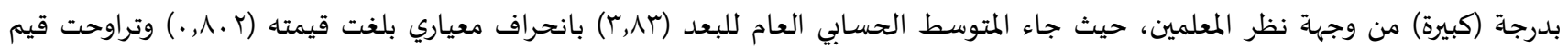

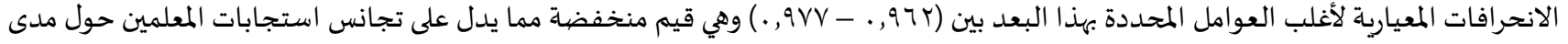

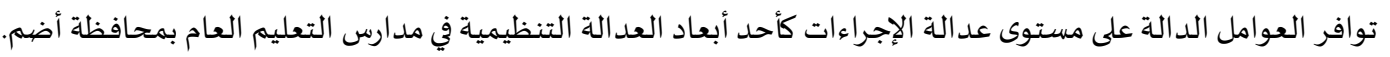

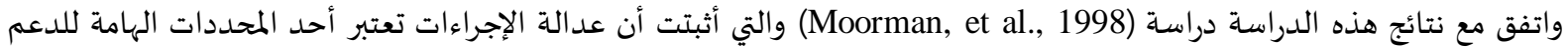

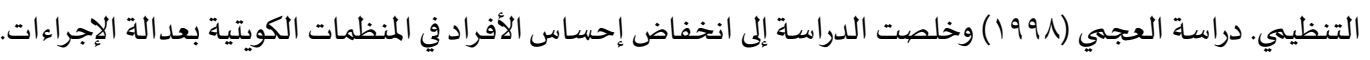

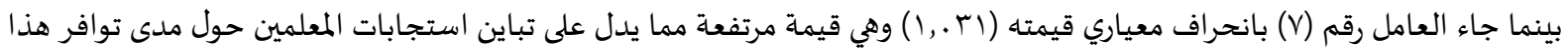

وجاء في الترتيب الأول من العوامل الدالة على مستوى عدالة الإجراءات كأحد أبعاد العدالة التنظيمية في مدارس التعليم العام بمحافظة

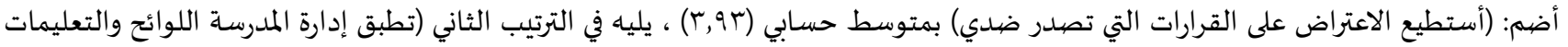

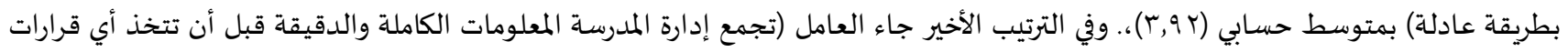

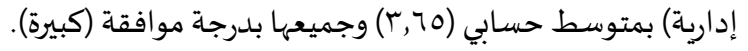

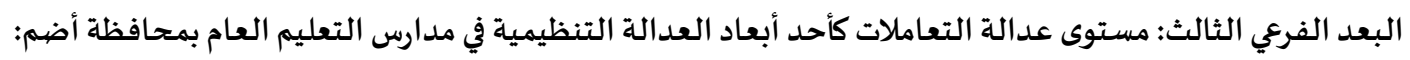

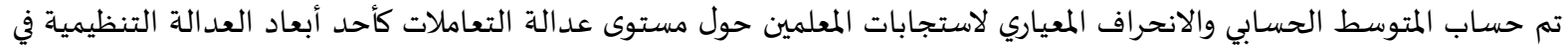

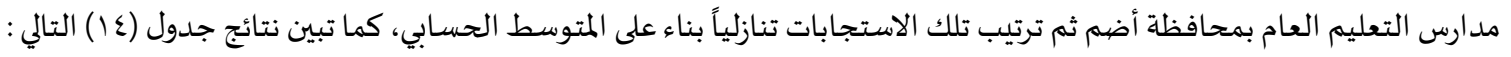


جدول(ع) (ا): المتوسطات الحسابية والانحر افات المعيارية لاستجابات المعلمين حول مستوى عدالة التعاملات كأحد أبعاد العدالة التنظيمية في مدارس التعليم العام بمحافظة أضهم ، مرتبة تنازلياً

\begin{tabular}{|c|c|c|c|c|c|}
\hline 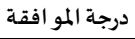 & ترتيب العبارة & الانحراف المعياري & المتوسط الحسابي & 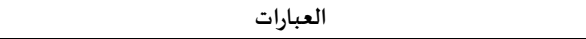 & رقم العبارة \\
\hline كبيرة & 1 &., $9 \varepsilon \varepsilon$ & r,q६ & يتسم حل الخلافات بين العاملين في المدرسـة بالنزاهة & ir \\
\hline 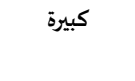 & r & $\cdot, 97 \varepsilon$ & $\mathrm{r}, \Lambda \Lambda$ & توظيفتيني إدارة المدرسة في النتائج عندما تتخذ أي قرارٍ يتعلق & 11 \\
\hline كبيرة & $r$ &., 99. & $r, \wedge 0$ & تبدي إدارة المدرسة اهتماماً بمصلحتي & 1. \\
\hline 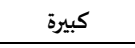 & $\varepsilon$ & $\cdot, 9 \wedge \mathrm{V}$ & $r, \wedge$. & تحرص إدارة المدرسة على تسخير مواردها لإنجاز مهامي الوظيفية & 9 \\
\hline
\end{tabular}

يتبين من جدول(ع ا) السابق أن مستوى عدالة التعاملات كأحد أبعاد العدالة التنظيمية في مدارس التعليم العام بمحافظة أضم جاء

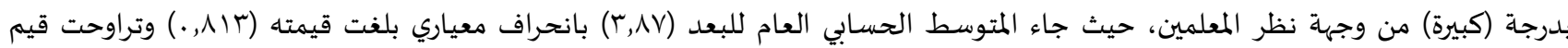
الانحرافات المعيارية للعوامل المحددة بهذا البعد بين (ع؟ 9, . - .99 9 . •) وهي قيم منخفضية مما يدل على تجانس استجابات المعلمين حول مدى توافر العوامل الدالة على مستوى عدالة التعاملات كأحد أبعاد العدالة التنظيمية في مدارس التعليم العام بمحافظة أضرافيم.

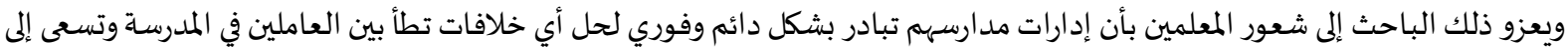

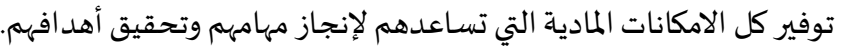

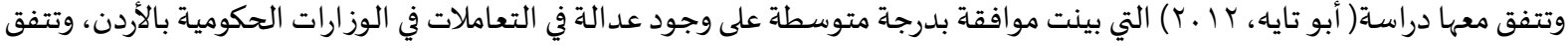

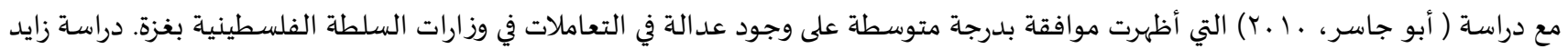
(1990) والتي ترى بأن العاملين أكثر إحساساً بعدالة التعاملات، ودراسة (Moorman, 1991) والتي استنتجت بأن العمالة أكثر إحساساً بعدالة التعاملات عن باقي أنواع العدالة التنظيمياة.

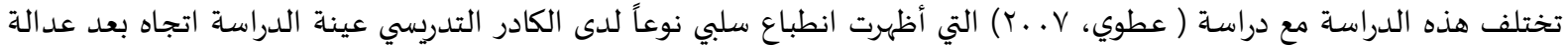

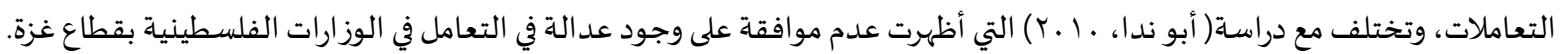

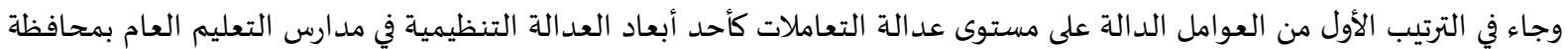
أضم: (يتسم حل الخلافات بين العاملين في المدرسة بالنزاهة) بمتوسط حسابي (ع, 9) ، يليه في الترتيب الثاني (تناقشني إدارة المدرسة في النتائج عندما

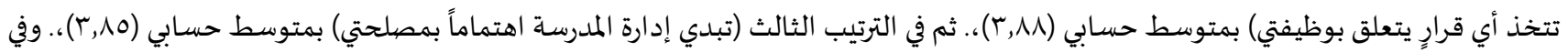
الترتيب الأخير جاء العامل (تحرص إدارة المدرسة على تسخير مواردها لإنجاز مهامي الوظيفية) بمتوسط حسابي (.ی,^) وجميعها بدرجة موافقة

البعد الثاني: مستوى أثرسلوك القادة لمسـاندة المرؤوسين كأحد أبعاد الدعم التنظيهي المدرك في مدارس التعليم العام بمحافظة أضم من وجهة نظر المعلمين: تم حساب المتوسط الحسابي والانحراف المعياري لاستجابات المعلمين حول مستوى أثر سلوك القادة لمساندة المرؤوسين كأحد أبعاد الدعم

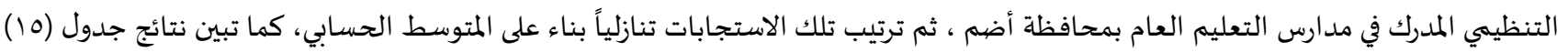

جدول(0) ): المتوسطات الحسابية والانحر افات المعيارية لاستجابات المعلمين حول مستوى أثرسلوك القادة لمساندة المرؤوسين كأحد أبعاد الدعم التنظييي

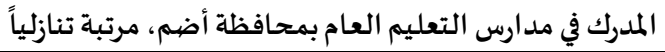

\begin{tabular}{|c|c|c|c|c|c|}
\hline درجة المو افقة & ترتيب العبارة & الانحراف المعياري & المتوسط الحسابي & 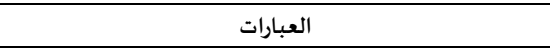 & 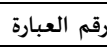 \\
\hline كبيرة جداً & 1 &., 979 & $\varepsilon, r$. & يبادرقائد المدرسة لمساعدتي عندما أواجه أي مشكلة في العمل & ir \\
\hline كبيرة & r &., , $0 \mathrm{~V}$ & $\varepsilon, 1 \gamma$ & يشجع قائد المدرسة روح التعاون بين المعلمين & rr \\
\hline كبيرة & $r$ &.,$\Lambda 94$ & $\varepsilon, 17$ & يشجع قائد المدرسة روح المبادرة لدى المعلمين & $r$. \\
\hline كبيرة & $\varepsilon$ &., А V & $\varepsilon, .9$ & يبدي قائد المدرسة اهتماماً بالأفكار المتعلقة بتحسين الأداء & 17 \\
\hline كبيرة & $\circ$ &., 919 & $\varepsilon, \cdot v$ & يكسب قائد المدرسة تأييد المعلمين بفعل حسن التواصل معهم & 11 \\
\hline كبيرة & 7 & $\cdot, 9 \wedge \mathrm{r}$ & $\varepsilon, \cdot r$ & المعلمين قائد المدرسة بتقوية العلاقات الاجتماعية بين جميع & IV \\
\hline كبيرة & $\mathrm{r}$ & $1, .+49$ & $r, 97$ & يمتلك قائد المدرسة مهارات فن الحواروالمناقشة والإقناع & ri \\
\hline كبيرة & $\Lambda$ & $1, .1 \pi$ & $r, q 4$ & يحرص قائد المدرسة على مناقشة أفكار المعلمين & 19 \\
\hline كبيرة & 9 & $1, . \mathrm{rr}$ & $r, 91$ & يضع قائد المدرسة إسعاد العاملين ضمن أولوياته & rr \\
\hline كبيرة & 1. & 1,149 & $r, \mathrm{r} \varepsilon$ & لرفح مستوى الدافعية والإنجاز لديّ فإن قائد المدرسة يعتمد & $1 \varepsilon$ \\
\hline
\end{tabular}




\begin{tabular}{|c|c|c|c|c|c|}
\hline & & & & وسائل التحفيز المعنوي والمادي لتحقيق ذلك & \\
\hline كبيرة & 11 & $1, .09$ & $r, 7 \varepsilon$ & المدرسة مقنعيع المعلمين بأن الامتيازات الممنوحة لهم من قائد & 10 \\
\hline
\end{tabular}

يتبين من جدول (10) السابق أن مستوى أثر سلوك القادة لمساندة المرؤوسين كأحد أبعاد الدعم التنظيمي المدرك في مدارس التعليم العام

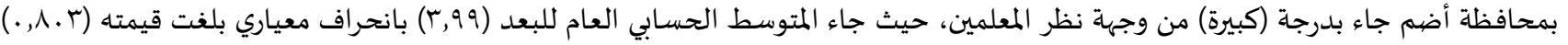

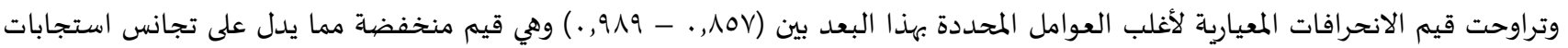

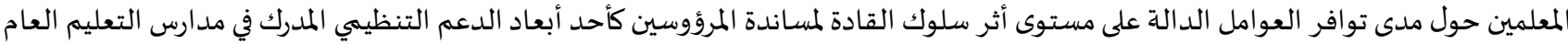
بمحافظة أضم.

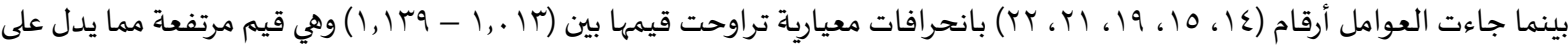
تباين استجابات المعلمين حول مدى توافر هذه العوامل.

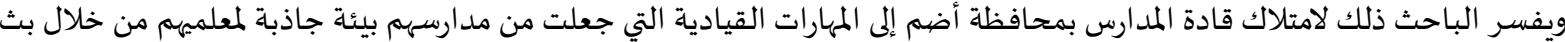
روح التعاون والتنافس بين المعلمين، والسعي بشكل متواصل لخلق جو مدرسي يستطيع من خلاله المعلم تحقيق أهدافه، وكذلك العمل على مناقشأسة

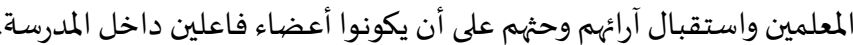
وتتفق نتائج هذه الدراسة مع دراسة باك (Pack, 2005) والتي أظهرت ارتفاع ملحوظ لمساندة القادة للمرؤوسين في استطلاع لاستجابات العاملين في مؤسسة رياضية في الولايات المتحدة الأمريكية.

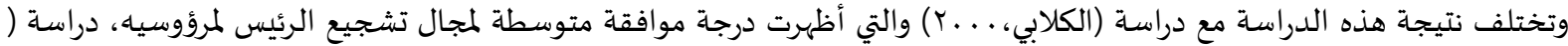

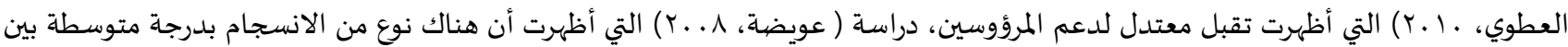

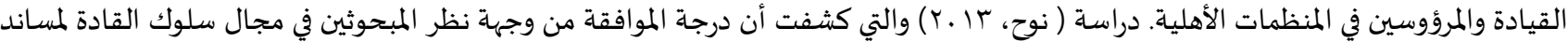
ل للمرؤوسين كانت متوسطة. وجاء في الترتيب الأول من العوامل الدالة على مستوى أثر سلوك القادة لمساندة المرؤوسين كأحد أبعاد الدعم التنظيمي المدرك في مدارس

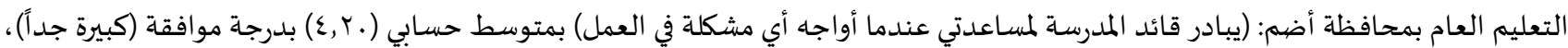

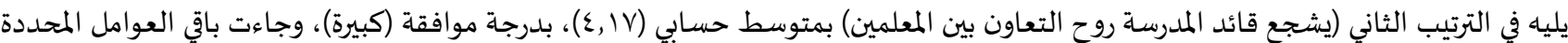

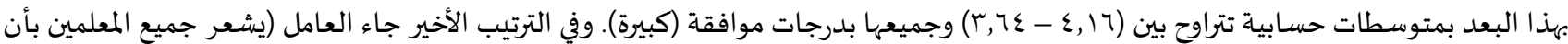

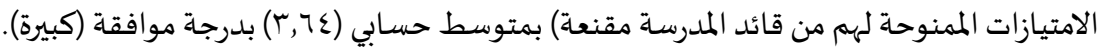

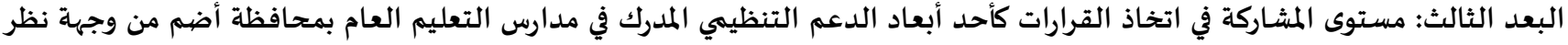
المعلمين: تم حساب المتوسط الحسابي والانحراف المعياري لاستجابات المعلمين حول مستوى المشاركة في اتخاذ القرارات كأحد أبعاد الدعم التنظيمي

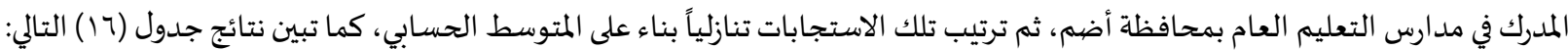
جدول(17): المتوسطات الحسابية والانحر افات المعيارية لاستجابات المعلمين حول مستوى المشاركة في اتخاذ القرارات كأحد أبعاد الدعم التنظيي المدرك في

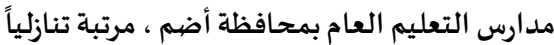

\begin{tabular}{|c|c|c|c|c|c|}
\hline درجة المو افقة & ترتيب العبارة & الانحراف المعياري & المتوسط الحسابي & 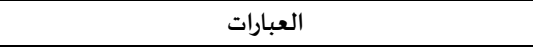 & رقم العبارة \\
\hline 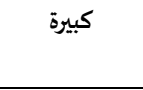 & 1 & $\cdot, 909$ & $r, 90$ & وأشارك بقدر كبير في القرارات المرتبطة بتخصصي & rV \\
\hline 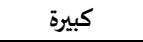 & r & $\cdot, \wedge \mathcal{M}$ & $r, 9 \varepsilon$ & تراعي إدارة المدرسة مصلحتي ذات العلاقة بعملي & $r \varepsilon$ \\
\hline 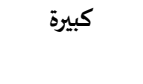 & r & $\cdot, 917$ & $r, 9 \varepsilon$ & تمنح إدارة المدرسة المملميلن صلالاحيات تخولهم أن يؤدوا & ro \\
\hline 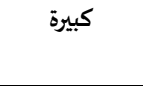 & $\varepsilon$ &., $9 \vee \varepsilon$ & $r, \Lambda 7$ & تمنح إدارة المدرسة المعلمين صلاحية تحديد شكل وملامح & rT \\
\hline 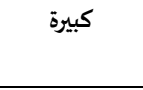 & 0 & $1, .71$ & $r, \mathrm{VA}$ & تتخذ أي قراريخص المدرسة على تبادل الآراء مع المعلمين قبل أن & r. \\
\hline 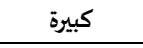 & 7 & $1, . \mathrm{rV}$ & $r, \mathrm{~V}$ & تفوض إدارة المدرسة جزءاً من صلاحياتها للعاملين معها & rq \\
\hline 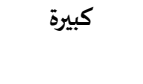 & $v$ & $1, . \mathrm{r}$ & $r, v\urcorner$ & تهنم إدارة المدرسة بدو افع وحاجات المعلمين عندما يتخذ & ru \\
\hline 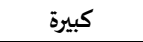 & -- & . 110 & $r, \wedge 7$ & لد الثالث : المششاركة في اتخاذ القرارات & 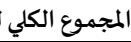 \\
\hline
\end{tabular}


يتبين من جدول(7) السابق أن مستوى المشاركة في اتخاذ القرارات كأحد أبعاد الدعم التنظيمي المدرك في مدارس التعليم العام بمحافظة

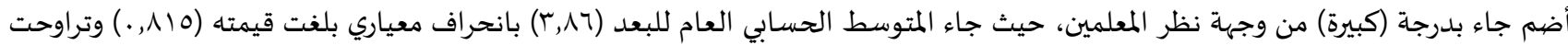

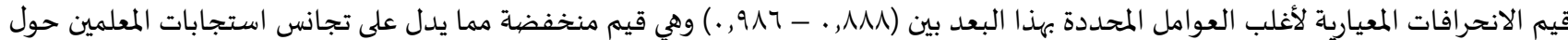

مدى توافر العوامل الد الة على مستوى المشاركة في اتخاذ القرارات كأحد أبعاد الدعم التنظيمي المدرك في مدارس التعليم العام بمحافظة أضمى ويعزو الباحث ذلك إلى فهم إدارات المدارس بالدور الحقيقي للمعلمين وأنهم شركاء نجاح للمؤسسة التعليمية ومن خلال مشاركتهم في القرارات التي تخص المدرسهم يجعلهم حريصين على تحقيق أهداف المدرسة، وكذلك حرص إدارات المدارس على منح المعلمين بعض الصلاحيات التي

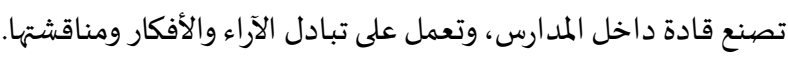

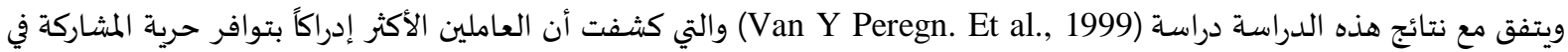

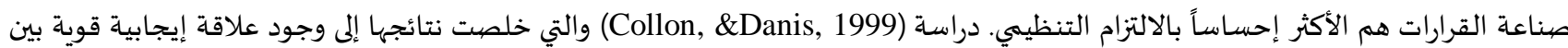
المشاركة في اتخاذ القرارات والالتزام التنظيمي. دراسة (Varma. 1999) والتي توصلت إلى أن المشاركة في اتخاذ القرارات تؤدي إلى زيادة الالتزام التنظيمي. ويختلف مع دراسة (نوح، با ـ †) والتي كشفت نتائجها أن درجة الموافقة من وجهة نظر المبحوثين في مجال المشاركة فيا اتخاذ القرارات كانت متوسطة

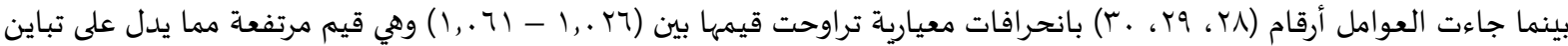
استجابات المعلمين حول مدى توافر هذه العوامل. وجاء في الترتيب الأول من العوامل الدالة على مستوى المشاركة في اتخاذ القرارات كأحد أبعاد الدعم التنظيمي المدرك في مدارس التعليم العام بمحافظة أضم: (أشارك بقدر كبير في القرارات المرتبطة بتخصصي وواجباتي الوظيفية) بمتوسط حسابي (Y,90)، يليه في الترتيب الثاني (تراعي

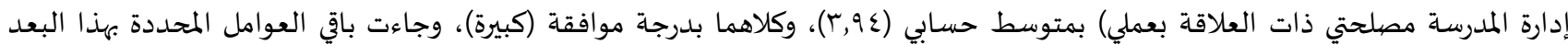

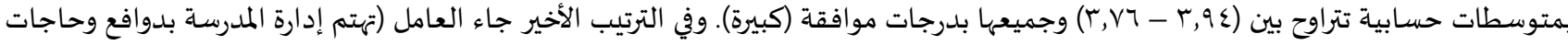

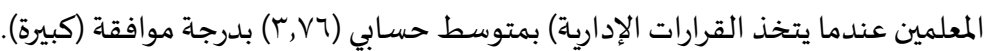
بشكل عام لاحظ الباحث أن نسبة مشاركة المعلمين في اتخاذ القرارات كبيرة ويعزو ذلك لرغبة قائدي المدارس في أن يشاركهم المرؤوسين في

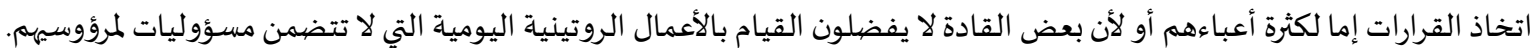
تتفق نتائج هذه الدراسة مع دراسة ( البلبيسي، ب ( ب) التي أظهرت أن المنظمات الغير حكومية تحرص على تنمية القدرات الإدارية والقيادية

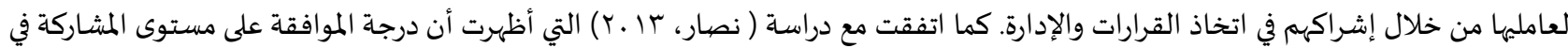

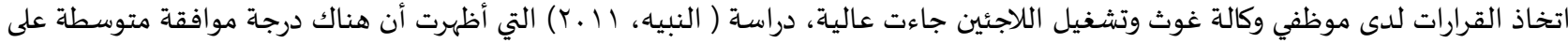

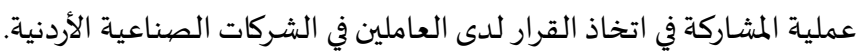

واختلفت هذه الدراسة مع دراسـة ( الشنطي، 7 . .ب) التي أظهرت ميل القيادة الإدارية في وزارات السلطة الفلسطينية بقطاع غزة إلى اتباع

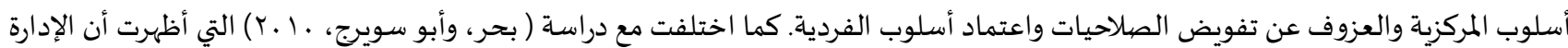
لا تحرص على إشراك المرؤوسين في اتخاذ القرارات.

البعد الر ابع: مستوى أثردعم وتأكيد الذات لدى المعلمين كأحد أبعاد الدعم التنظيمي المدرك في مدارس التعليم العام بمحافظة أضمى من وجهة نظر المعلمين:

تم حساب المتوسط الحسابي والانحراف المعياري لاستجابات المعلمين حول مستوى أثر دعم وتأكيد الذات لدى المعلمين كأحد أبعاد الدعم

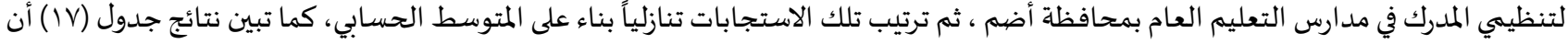

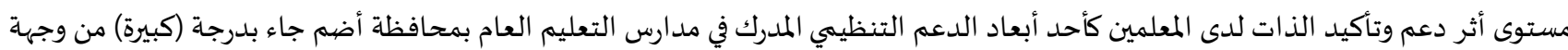
نظر المعلمين، حيث جاء المتوسط الحسابي العام للبعد (1 .,ع) بانحراف معياري بلغت قيمته (707,..) وتراوحت قيم الانحرافات المعيارية لأغلب

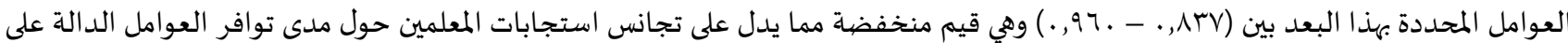
مستوى أثر دعم وتأكيد الذات لدى المعلمين كأحد أبعاد الدعم التنظيمي المدرك في مدارس التعليم العام بمحافظة أضمه. 
جدول(V) المتوسطات الحسابية والانحر افات المعيارية لاستجابات المعلمين حول مستوى أثردعم وتأكيد الذات لدى المعلمين كأحد أبعاد الدعم التنظيمي المدرك في مدارس التعليم العام بمحافظة أضهم، مرتبة تنازلياً

\begin{tabular}{|c|c|c|c|c|c|}
\hline المو افقة & العبارة & المعياري & المسابي & 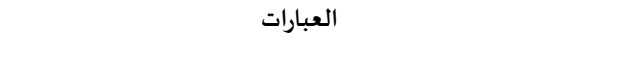 & 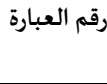 \\
\hline كبيرة جداً & 1 & $\cdot, \wedge 99$ & $\varepsilon, \varepsilon \wedge$ & أعتزو أفتخربالمهنة التي أعمل بها & ro \\
\hline كبيرة جداً & r & . ArV & $\varepsilon, r V$ & يساعدني الاستقرارفي عملي على الإبداع بشكل مستمر & $r_{\Lambda}$ \\
\hline كبيرة جداً & $r$ & $\cdot$, ATr & $\varepsilon, r \pi$ & تتسم مهنتي كمعلم بالتحدي & rq \\
\hline كبيرة جداً & $\varepsilon$ & $\cdot, \wedge T \varepsilon$ & $\varepsilon, Y r$ & تعتز إدارة المدرسة بي عند تحقيقي لإنجازات مهمة & $r$ \\
\hline كبيرة & 0 & $\cdot$, AVI & $\varepsilon, 11$ & تقدر إدارة المدرسة مساهماتي عندما يتطلب الوضع ذلك & rr \\
\hline 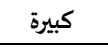 & 7 & $\cdot, \wedge 71$ & $\varepsilon, \ldots$ & تراعي إدارة المدرسة التي أعمل بها أهدافي وقييي & r \\
\hline 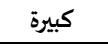 & $v$ &., 97. & $r, \wedge 9$ & أشعربأن إدارة المدرسة تساعدني على تحقيق ذاتي & $r \varepsilon$ \\
\hline 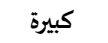 & $\wedge$ & $1, .0 \varepsilon$ & $r, \Lambda$. & توفرلي إدارة المدرسة فرص تنمية المهارات التي تساعدني لإنجاز العمل & $\varepsilon$. \\
\hline كبيرة & 9 & $1, Y \cdot \varepsilon$ & $r, 00$ & يقدر المجتمع الجهود التي أبذلها والعمل الذي أقوم به داخل المدرسة & ri \\
\hline كبيرة & 1. & $1,1 \mathrm{VA}$ & $r, \Sigma 7$ & يقدر المجتمع الجهود التي أبذلها والعمل الذي أقوم به خارج المدرسة & rv \\
\hline كبيرة & --- &., 707 & $\varepsilon, .1$ & \multicolumn{2}{|c|}{ لمجموع الكلي للبعد الر ابع : أثردعم وتأكيد الذات لدى المعلمين } \\
\hline
\end{tabular}

ويعزو الباحث حصول هذا البعد على درجة كبيرة في التأثير كأحد أبعاد الدعم التنظيمي المدرك في مدارس التعليم العام بمحافظة أضم إلى شعور المعلم بالرضا عن نفساه عند شغله وظيفة في سلك التعليم لما ستحققه له من أمان وظيفي ومكانه مرموقة في المجتمع، وشعوره بأهمية دوره في تعليم وبناء جيل واعد من المبدعين والرواد.

تتفق هذه الدراسة مع نتائج دراسة (Arshadi \&Hayavi, 2013, P738) والتي تشير إلى تأثير الدعم التنظيمي المدرك بشكل إيجابي على

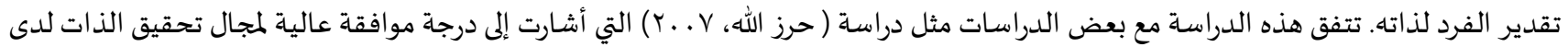
معلمي المدارس الثانوية بغزة حيث يشعر المعلم بمكانته وأنه صاحب الفضل في تخريج الطلاب وأنه شخص منتج في المجتمع، دراسة العفيفي (1999)

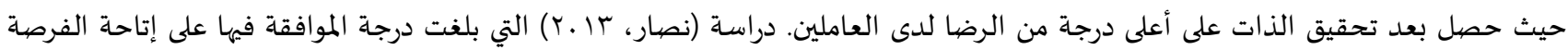

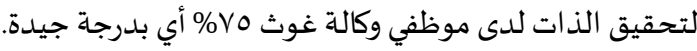

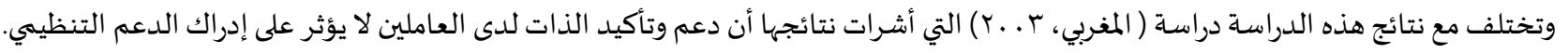

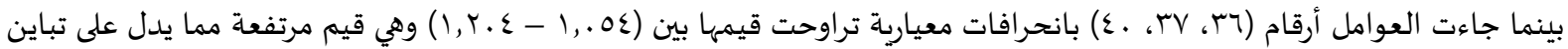

استجابات المعلمين حول مدى توافر هذه العوامل. وجاء في الترتيب الأول من العوامل الدالة على مستوى أثر دعم وتأكيد الذات لدى المولى المعلمين كأحد أبعاد الدعم التنظيمي المدرك في مدارس

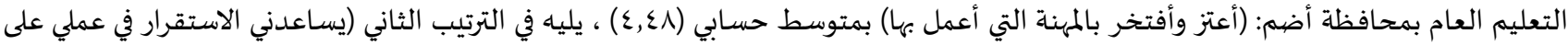

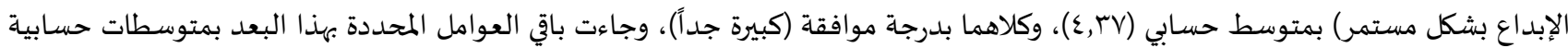

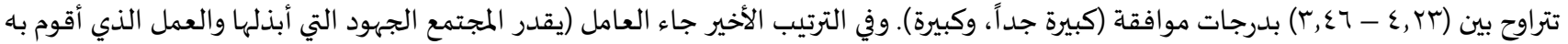

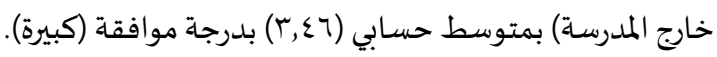

إجابة السؤال الثاني:" ما مستوى الالتزام التنظيهي لدى معلمي مدارس التعليم العام بمحافظة أضهم من وجهة نظرهم؟". ولإجابة على هذا السؤال، فقد تم حساب المتوسط الحسابي والانحراف المعياري لأبعاد المحور الثاني من الاستبانة (مستوى الالتزام التنظيمي لدى معلمي مدارس التعليم العام بمحافظة أضم) والتي حددها الباحث في ثلاثة أبعاد، ومن ثم ترتيب هذه الأبعاد تنازلياً حسب المتوسط

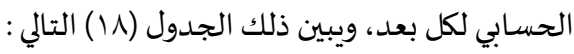

جدول(1) ): المتوسطات الحسابية والانحر افات المعيارية لأبعاد استبانة (مستوى الالتزام التنظيمي لدى معلمي مدارس التعليم العام بمحافظة أضم)، مرتبة تنازلياً

\begin{tabular}{|c|c|c|c|c|c|}
\hline درجة المو افقة & ترتيب البعد & الانحراف المعياري & المتوسط الحسابي & البعد & رقم البعد \\
\hline كبيرة & 1 &., 100 & $r, \wedge \mathrm{V}$ & الالتزام العاطفي & 1 \\
\hline كبيرة & r &., 170 & $r, v$. & الالتزام المعياري & $r$ \\
\hline كبيرة & $r$ & ., А9т & $r, 00$ & الالتزام الاستمراري & $r$ \\
\hline كبيرة & --- & ., VqV & $r, V r$ & \multicolumn{2}{|c|}{ المجموع الكلي (مستوى الالتزام التنظيهي لدى مدارس التعليم العام } \\
\hline
\end{tabular}

يتبين من جدول (1) السابق أن مستوى الالتزام التنظيمي لدى معلمي مدارس التعليم العام بمحافظة جاء بدرجة (كبيرة) من وجهة نظرهم

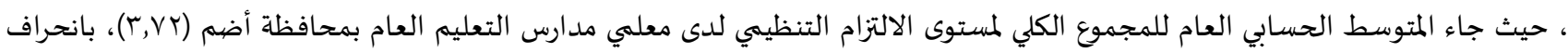




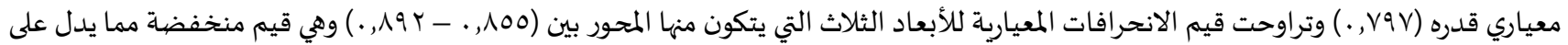
تجانس استجابات معلمي مدارس التعليم العام بمحافظة أضمى حول مستوى الالتزام التنظيمي لديهم.

ويفسر الباحث حصول مستوى الالتزام التنظيمي لدى معلمي مدارس التعليم العام بمحافظة أضم على درجة (كبيرة) من وجهة نظرهم لأن

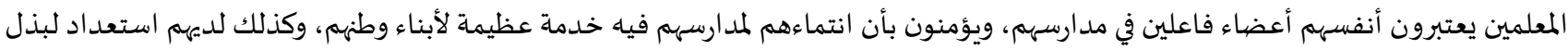
كل ما في وسعهم من أجل النهوض بعملهم، والارتقاء باه، وكذلك فخرهم بما يقدون من أعمال ومساعدات لطلابهم وللمجتمع الذي يعيشون فياء،

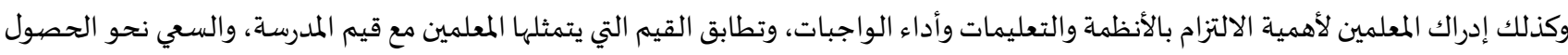
على مرتبة وظيفية متميزة في المدرسة وتحقيق الطموح.

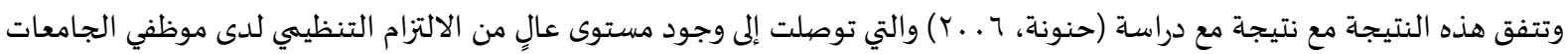

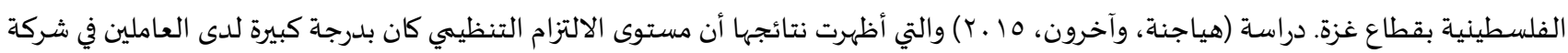

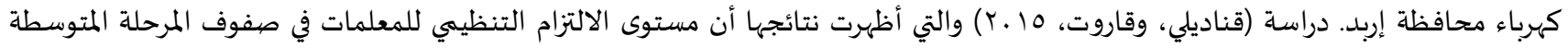

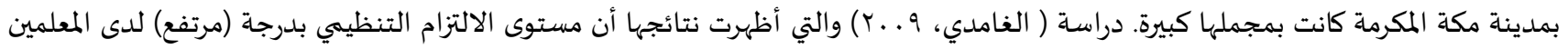

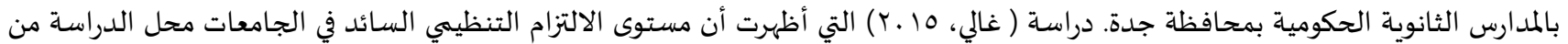

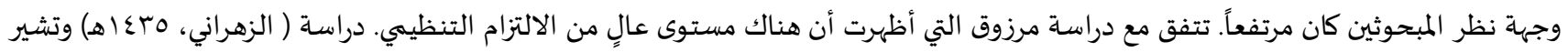

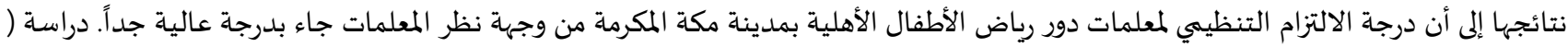

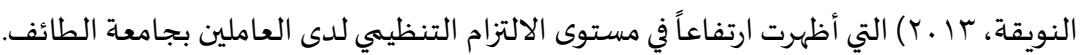
بينما تختلف مع نتيجة دراسة ( مرزوق، 17 ـ †) والتي أظهرت نتائجها أن العاملين بإدارة الجامعة وكلياتها يدركون درجة متوسطة من الالتزام التنظيمي. دراسة ( خضير وآخرون، 1971) التي أشارت إلى أن درجة الالتزام التنظيمي لدى أعضياء هيئة التدريس في كليات جامعة بغداد جاء بدرجة

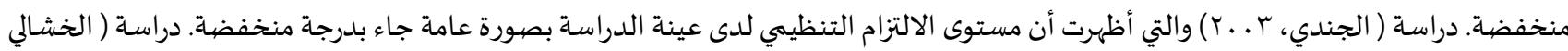

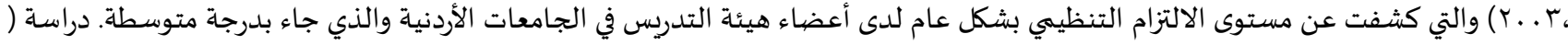

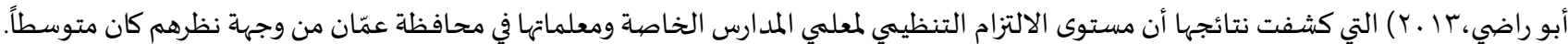

دراسة ( العوضي، Y ا ـ Y) التي أظهرت نتائجها أن درجة الالتزام التنظيمي لمعلمي المدارس الابتدائية في دولة الكويت من وجهة نظرهم كانت متوسطة. كما يتبين من الجدول السـابق أن مستوى الالتزام التنظيمي لدى معلمي مدارس التعليم العام بمحافظة أضمى في بعد (الالتزام العاطفي) جاء

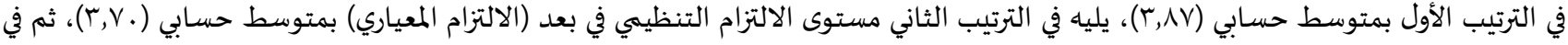

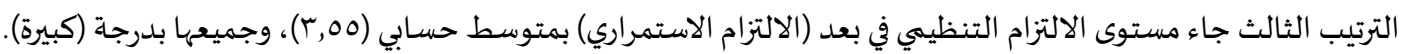

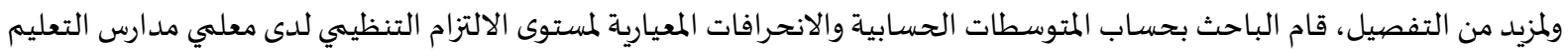

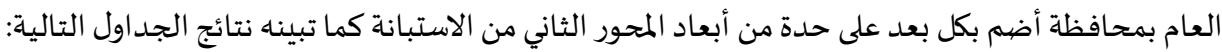

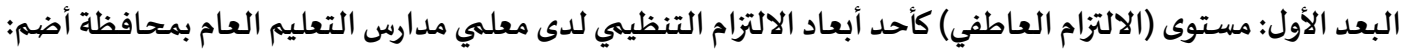
تم حساب المتوسط الحسابي والانحراف المعياري لاستجابات معلمي مدارس التعليم العام بمحافظة أضهم حول مستوى (الالتزام العاطفي)

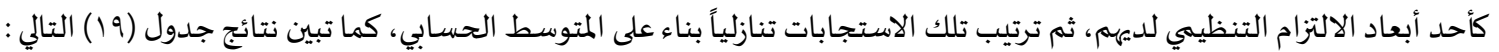
جدول(19): المتوسطات الحسابية والانحر افات المعيارية لاستجابات معلمي مدارس التعليم العام بمحافظة أضهم حول مستوى (الالتزام العاطفي) كأحد أبعاد الالتزام التنظيمي لديهم، مرتبة مدئة تنازلياً

\begin{tabular}{|c|c|c|c|c|c|}
\hline المو افقة & 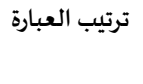 & المعياري & المسابي & 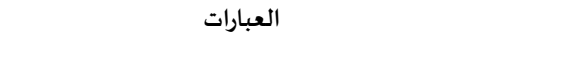 & 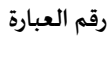 \\
\hline كبيرة & 1 &., 90. & $\varepsilon, .0$ & أشعر أنني فرد من أفراد العائلة في هذه المدرسة & $\varepsilon \varepsilon$ \\
\hline كبيرة & $r$ & $1, . \mathrm{rq}$ & $\varepsilon, \varepsilon$ & تعني لي مدرستي الكثير بشكل شخصي & $\varepsilon 7$ \\
\hline كبيرة & $r$ &., $9 \vee \mathrm{V}$ & $\varepsilon, .1$ & أستمتع بالحديث عن المدرسة التي أعمل بها مع الآخرين & $\varepsilon$ \\
\hline كبيرة & $\varepsilon$ & $1, .1$ & $r, 91$ & أشعر أن هناك ارتباطاً نفسياً بيني وبين المدرسة & ¿० \\
\hline كبيرة & 0 & $1, .0 \varepsilon$ & $r, \wedge \Lambda$ & أشعرحقاً أن مشاكل المدرسة هي مشاكلي أنا شخصياً & $\varepsilon r$ \\
\hline كبيرة & 7 & $1, . r Y$ & $r, \wedge \uparrow$ & أشعر أن عملي بالمدرسة ينبع من ارتباطي بها عاطفياً & $\varepsilon \wedge$ \\
\hline كبيرة & $\mathrm{v}$ & $1, .0$ & $r, \mathrm{ru}$ & تهتم إدارة المدرسة بحاجاتي الشخصية التي أفصح عنها & $\varepsilon V$ \\
\hline كبيرة & $\wedge$ & $1, r$ r. & $r, 01$ & أشعر أنه من الصعب عليَ أن أرتبط بمدرسة آخرى غيرمدرستي & $\varepsilon r$ \\
\hline كبيرة & --- & $\cdot, 100$ & $r, A \gamma$ & \multicolumn{2}{|c|}{ المجموع الكلي للبعد الأول : الالتزام العاطفي } \\
\hline
\end{tabular}




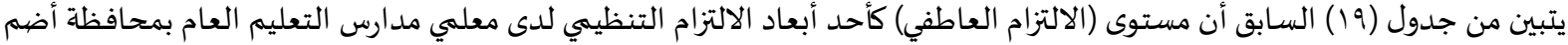

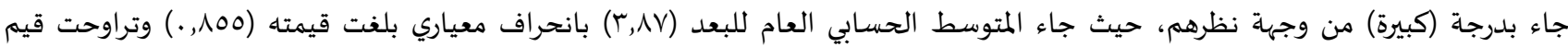

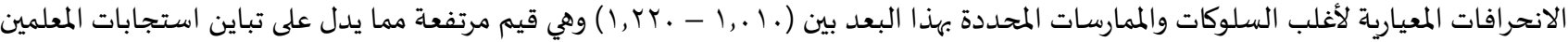

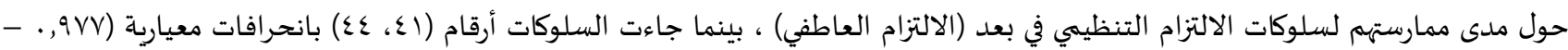
.90, . .) على الترتيب، وهي قيم منخفضة مما يدل على تجانس استجابات المعلمين على ممارستهم لتلك السلوكات. يمكن تفسير حصول مستوى الالتزام التنظيمي لدى معلمي مدارس التعليم العام بمحافظة أضم في بعد (الالتزام العاطفي) على الترتيب الأول بدرجة (كبيرة) من وجهة نظرهم ويعزو ذلك الباحث إلى حب المعلمين لمدارسهم واستعدادهم لبذل المزيد من الجهيد مقابل تحقيق مدارسهم نجاحات أكبر، بالإضافة إلى تجانس الميول والتوجهات لدى الماندان المعلمين في مدارس مكتب التعليم بمحافظة أضمه، ويشعرون بالفخر والاعتزاز والثقة تجاه مدارسهم، وأن لهذه المدارس مكانة عالية في أنفسهم.

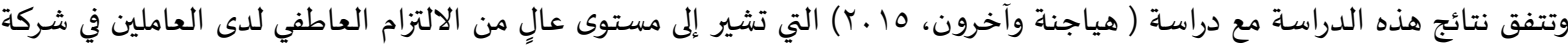

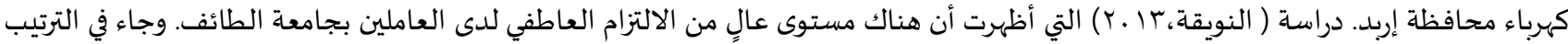

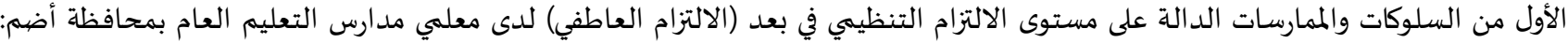

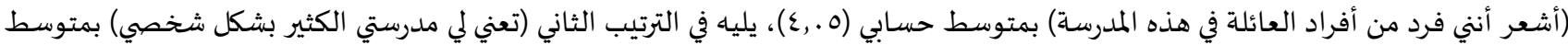

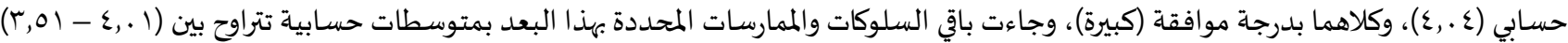
وجميعها بدرجة موافقة (كبيرة). وفي الترتيب الأخير جاء السلوك (أشعر أنه من الصعب عليّ أن أرتبط بمدرسة آخرى غير آير مدرستي) بمتوسط حسابي الماتي

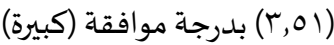

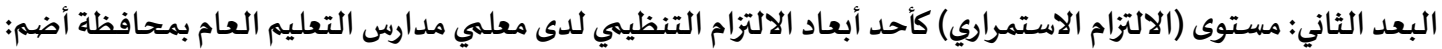
تم حساب المتوسط الحسابي والانحراف المعياري لاستجابات معلمي مدارس التعليم العام بمحافظة أضم حول مستوى (الالتزام الاستمراري) كأحد الأدادي

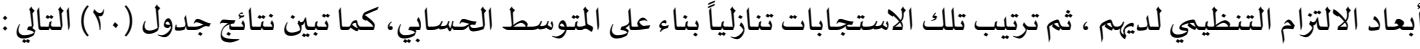
جدول(rr): المتوسطات الحسابية والانحر افات المعيارية لاستجابات معلمي مدارس التعليم العام بمحافظة أضم حول مستوى (الالتزام الاستمراري) كأحد أبعاد الالتزام التنظيهي لديهم ، مرتبة تنازلياً

\begin{tabular}{|c|c|c|c|c|c|}
\hline درجة & ترتيب & الانحراف & المتوسط & العبارات & رقم العبارة \\
\hline & العبارة & & & & \\
\hline كبيرة & 1 & $1,1 \% \varepsilon$ & $r, 71$ & يعكس عملي في المدرسة ضرورة حاجتي للعمل أكثر من رغبتي فيه & o\& \\
\hline كبيرة & $r$ & $1, \mathrm{TMN}$ & $r, \pi$. & يصعب عليَ ترك المدرسة التي أعمل بها حالياً & or \\
\hline كبيرة & $r$ & $1, \mathrm{rqT}$ & $r, 09$ & يصعب علي ترك هذه المدرسة حتى لورغبت في ذلك & $\varepsilon 9$ \\
\hline كبيرة & $\varepsilon$ & $1, \mathrm{ryT}$ & $r, 01$ & يصعب علي أن أحصل على وظيفة شاغرة بمكان آخرلندرة الوظائف & or \\
\hline كبيرة & $\circ$ & $1, T Y \varepsilon$ & $r, 01$ & يسبب لي تركي العمل بالمدرسة إرباكاً شديداً & o. \\
\hline 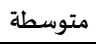 & 1 & $1, \pi T Y$ & 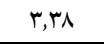 & يكلفني قراري بترك المدرسة التي أعمل بها الكثير & 01 \\
\hline كبيرة & --- & . A9r & $r, 00$ & \multicolumn{2}{|l|}{ لم لم لمبعد الثاني : الالتزام الاستمراري } \\
\hline
\end{tabular}

يتبين من جدول (.r) السابق أن مستوى (الالتزام الاستمراري) كأحد أبعاد الالتزام التنظيمي لدى معلمي مدارس التعليم العام بمحافظة

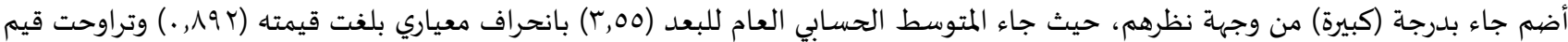

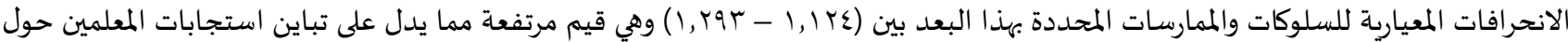
مدى ممارستهم لسلوكات الالتزام التنظيمي في بعد (الالتزام الاستمراري). أما حصول مستوى الالتزام التنظيمي لدى معلمي مدارس التعليم العام بمحافظة أضمى في بعد (الالتزام الاستمراري) على الترتيب الأخير الإني بدرجة (كبيرة) يعزى ذلك إلى أن المعلمين يضعون في اعتبارهم المكاسب الآنية والمستقبلية التي قد تعود عليهم في حال استمرارهم بالعمل ويجدون

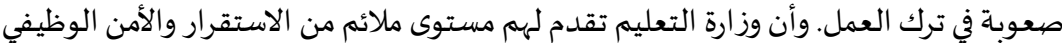

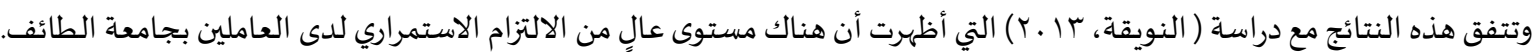
وتختلف نتائج هذه الدراسة مع دراسة ( هياجنة وآخرون، 10 .ب) والتي تشير إلى مستوى عالٍ من الالتزام الاستمراري. دراسة ( الخشالي،

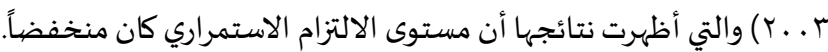

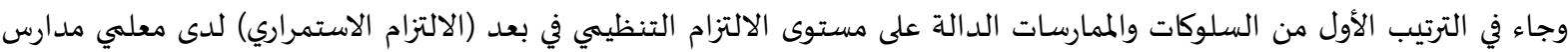

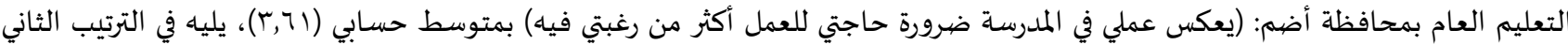


(يصعب عليّ ترك المدرسة التي أعمل بها حالياً) بمتوسط حسابي (.7,؟)، وكلاهما بدرجة موافقة (كبيرة)، وجاءت باقي السلوكات والممارسات المحددة

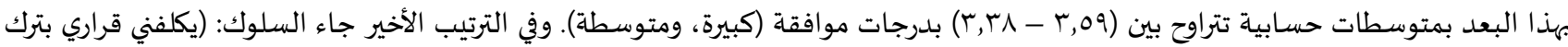

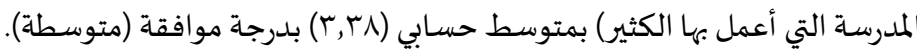

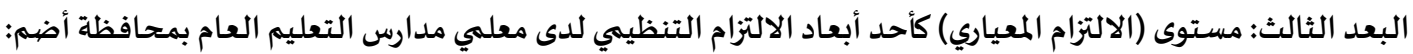
تم حساب المتوسط الحسابي والانحراف المعياري لاستجابات معلمي مدارس التعليم العام بمحافظة أضم حول مستوى (الالتزام المعياري)

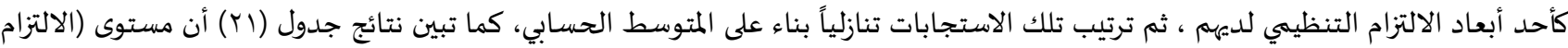

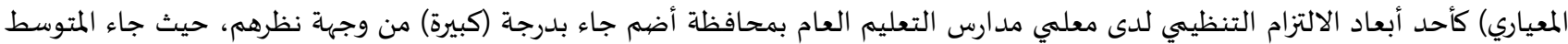

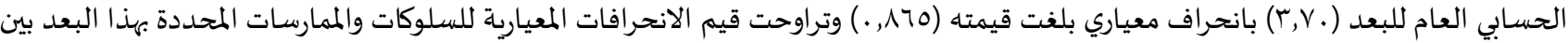

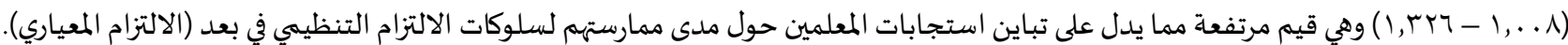
جدول(Y) : المتوسطات الحسابية والانحر افات المعيارية لاستجابات معلمي مدارس التعليم العام بمحافظة أضم حول مستوى (الالتزام المعياري) كأحد أبعاد

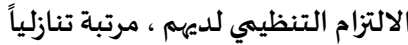

\begin{tabular}{|c|c|c|c|c|c|}
\hline 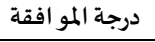 & ترتيب العبارة & الانحراف المعياري & المتوسط الحسابي & 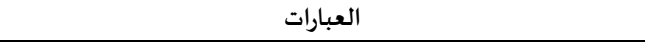 & 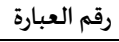 \\
\hline كبيرة جداً & 1 & $1, .1 \varepsilon$ & $\varepsilon, r Y$ & تستحق المدرسة التي أعمل بها إخلاصي لها & 71 \\
\hline كبيرة & r & $1, \ldots 1$ & $\varepsilon, . r$ & يشجعني التزامي الأخلاقي نحو المدرسة بالاستمرار للعمل بها & or \\
\hline كبيرة & $r$ & $1, .7 \mathrm{~V}$ & $\varepsilon, .1$ & أحس أنه من واجبي إظهارولائي الدائم للمدرسة التي أعمل بها & 00 \\
\hline كبيرة & $\varepsilon$ & $1, r \mu \varepsilon$ & $r, v q$ & تدفعني أخلاقياتي ألا أترك المدرسة & $\pi$ \\
\hline كبيرة & 0 & 1,YIr & $r, 71$ & أقدر الأشخاص الذين يقضون معظم حياتهم الوظيفية داخل مكان & 7. \\
\hline كبيرة & 1 & 1, ror & $r, 00$ & ألتزم بضرورة الولاء المستمرلوظيفة واحدة & 09 \\
\hline متوسطة & 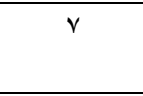 & $1, r Y 1$ & $r, r V$ & آخر أمتع عن ترك عملي بالمدرسة حتى لو اتيحت لي فرصة العمل بمكان & 01 \\
\hline 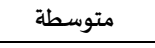 & $\wedge$ & 1,rYT & $r, 11$ & أعتقد أن التنقل المتكرر من مكان عمل إلى آخرهوسلوك غير لائق & 07 \\
\hline كبيرة & --- &., 170 & $r, \mathrm{r}$. & ل لبعد الثالث : الالتزام المعياري & المجموع الكلي \\
\hline
\end{tabular}

ويعزو الباحث حصول مستوى الالتزام التنظيمي لدى معلمي مدارس التعليم العام بمحافظة أضهم في بعد (الالتزام المعياري) على الترتيب

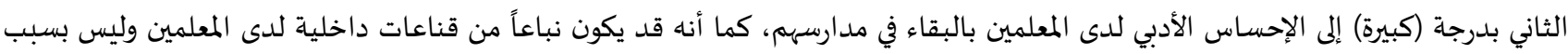

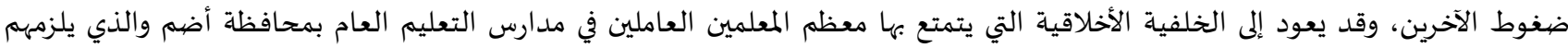
للاستمرار في عملهم، وعدم تركه من أجل تحقيق أهداف مادية أو شخصية.

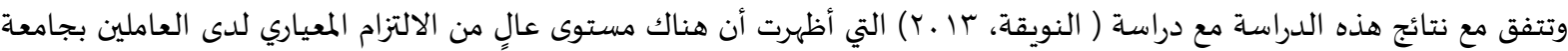

وتختلف مع دراسة ( هياجنة وآخرون، 10 ـ †) والتي أظهرت وجود مستوى متوسط من الالتزام المعياري لدى العاملين في شركة كهرباء إربد. وجاء في الترتيب الأول من السلوكات والممارسات الدالة على مستوى الالتزام التنظيمي في بعد (الالتزام المعياري) لدى معلمي مدارس التعليم

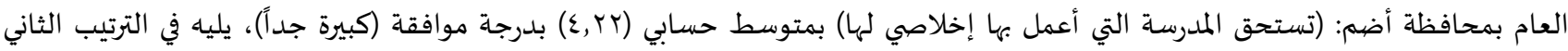
(يشجعني التزامي الأخلاقي نحو المدرسة بالاستمرار للعمل بها) بمتوسط حسابي (r .,ع)، بدرجة موافقة (كبيرة)، وجاءت باقي السلوكات والممارسات

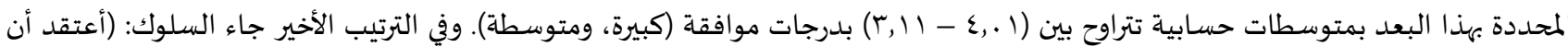

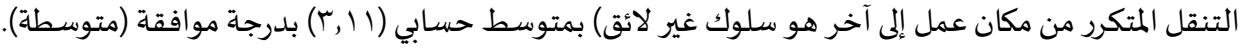
إجابة السؤال الثالث: " هل توجد علاقة ارتباطية ذات دلالة احصيائية بين مستوى الدعم التنظيمي كما يدركه المعلمون بمدارس إس التعليم العام

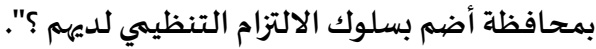
ولإجابة عن هذا السؤال فقد تم استخدام معامل ارتباط بيرسون بين درجات استجابات أفراد عينة الدراسة من المعلمين على المحور الأول (مستوى الدعم التنظيمي المدرك في مدارس التعليم العام بمحافظة أضم) و المحور الثاني (مستوى الالتزام التنظيمي لدى معلمي مدارس التعليم العام العام بمحافظة أضم) وجاءت النتائج كالتالي: 
جدول (rr): نتائج اختباربيرسون للعلاقة بين مستوى الدعم التنظيمي المدرك في مدارس التعليم العام بمحافظة أضم ومستوى الالتزام التنظيمي لدى

\begin{tabular}{|c|c|c|c|c|}
\hline \multicolumn{5}{|c|}{ المعلمين } \\
\hline مستوى الدلالة & معامل ارتباط بيرسون & الانحراف المعياري & المتوسط الحسابي & المتغيرات \\
\hline \multirow[t]{2}{*}{ **., ... } & \multirow[t]{2}{*}{$\cdot, \mathrm{VI}$} & $\cdot, 771$ & $r, q r$ & مستوى الدعم التنظيمي المدرك \\
\hline & & ., V9v & $r, v r$ & مستوى الالتزام التنظيمي لدى المعلمين \\
\hline
\end{tabular}

يتضح من الجدول (rr) السابق أن قيمة معامل ارتباط بيرسون بين مستوى الدعم التنظيمي المدرك في مدارس التعليم العام بمحافظة

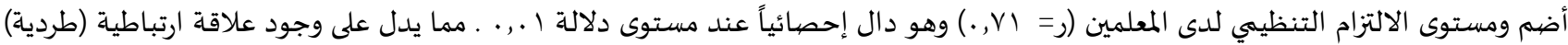
عالية القيمة وذات دلالة إحصائية عند مستوى دلالة (1 . . •) بين مستوى الدعم التنظيمي المدرك في مدارس التعليم العام بمحافظة أضهم ومستوى الالتزام التنظيمي لدى المعلمين. ويعزو الباحث ذلك إلى اهتمام المدارس بجميع أبعاد الدعم التنظيمي والتي من خلالها تحقق التزام عال لدى المعلمين، فعندما تتحقق

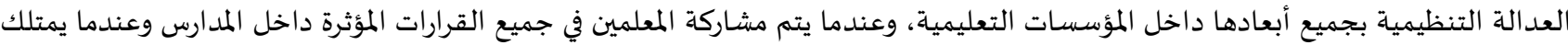
قادة المدارس المهارات والإمكانيات التي تؤهلهم ليكون قادة داعمين ومؤثرين في سير العملية التعليمية داخل مدارسهم ، وعندما يشعر المعلم باهتمام المدرسة بمشاكله وحاجاته وسعيها الدؤوب لتذليل جميع العقبات والصعاب ويحصل على التقدير والدعم المناسبين فإنه سيدرك أن المدرسة تقدم له له الدعم التنظيمي الذي يؤدي إلى تحقيق الالتزام التنظيمي. ويتفق مع هذه النتيجة دراسة (Eisenberger, et al., 2001) التي استنتجت وجود ارتباط إيجابي بين إدراك العامل للدعم التنظيمي

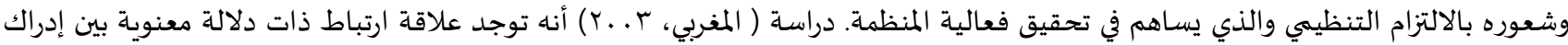
الأفراد للدعم التنظيمي وبين الالتزام التنظيمي للأفراد العاملين، ودراسة (Dawnay, et al., 2001) أوضحت بأن الدعم التنظيمي يولد الالتزام

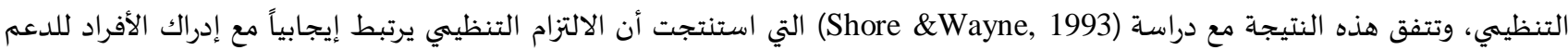
التنظيمي. من أهم نتائج دراسة (Colakoglu, 2010) أن الدعم التنظيمي يؤثر إيجابياً على الالتزام التنظيمي. دراسة يحيى (Yahya, 2012) والتي كشفت نتائجها أن الدعم التنظيمي يؤثر بشكل كبير على الالتزام التنظيمي. دراسة كوري، ودوليري (Currie \&Dollery, 2006) والتي أظهرت نتائجها أن الالتزام التنظيمي يتأثر وبشكل إيجابي بالدعم التنظيمي المدرك. دراسة ليو (Liu, 2009) والتي توصلت إلى أن الدعم التنظيمي قد أظهر قوة تأثير كبيرة في الالتزام التنظيمي، و(البوريني، 11 إب) التي استنتجت أن هناك علاقة كبيرة بين الدعم التنظيمي المدرك والالتزام التنظيمي. دراسة والتي كشفت نتائجها بأن الدعم التنظيمي يؤثر على الالتزام التنظيمي. دراسة (Moorman, et al., 1998) على أن إدراك الموظف للدعم التنظيمي يرتبط إيجابياً بالالتزام التنظيمي. دراسة (Knippenberg and Sleebo, 2006) التي أكدت نتائجها أن الالتزام

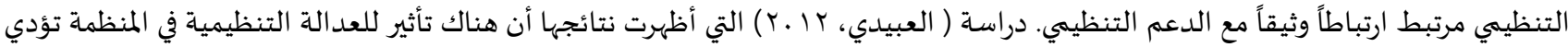

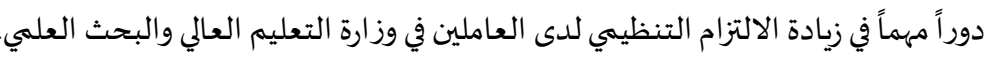
كما تم حساب معامل ارتباط بيرسون بين درجات استجابات المعلمين من أفراد عينة الدراسة على الأبعاد الداخلية لكل من المحسور الأول

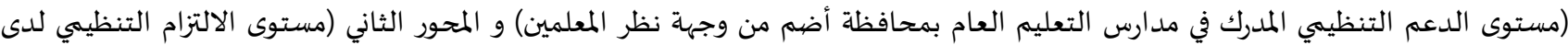
معلمي مد ارس التعليم العام بمحافظة أضهم) ، ويوضح الجدول التالي تلك النتائج :

جدول (rr): مصفوفة معاملات الارتباط بين أبعاد مستوى الدعم التنظيمي المدرك في مدارس التعليم العام بمحافظة أضمى و أبعاد الالتزام التنظيمي لدى

المعلمين

\begin{tabular}{|c|c|c|c|c|}
\hline 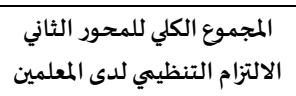 & 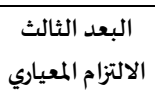 & الالتزام الاستمراري الثاني & 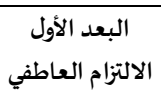 & 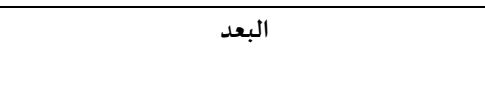 \\
\hline$* *, \pi$ & $*^{* *}, 00$ & $*^{* *}, 01$ & $* *$, TV & البعد الأول: العدالة التنظيمية \\
\hline$* * ., 70$ & **., or & $*^{* *}, 00$ & $*^{* *}, \mathrm{r}$. & البعد الثاني: أثرسلوك القادة لمساندة المرؤوسين \\
\hline$* * ., 70$ & $*^{* *}, 00$ & $*^{* *}, 00$ & $* * ., 79$ & البعد الثالث: المشاركة في اتخاذ القرارات \\
\hline **., IV & **., Tr & **.,or & $* * ., 79$ & البعد الر ابع: أثردعم وتأكيد الذات لدى المعلمين \\
\hline$*^{* *}, \mathrm{VI}$ & $* * ., 71$ & **.,01 & $*^{* *}$, , vo & 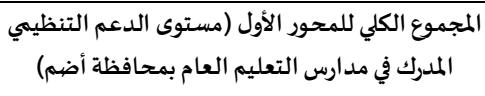 \\
\hline
\end{tabular}

** دال إحصائياً عند (1 . . . ) 
يتضح من الجدول (rr) السابق ما يلي: ا. جاء معامل ارتباط البعد الأول (الالتزام العاطفي) كأحد أبعاد الالتزام التنظيمي لدى معلمي مدارس التعليم العام بمحافظة أضهم بالمجموع الكلي لمستوى الدعم التنظيمي المدرك في مدارس التعليم العام بمحافظة أضم من وجهة نظر المعلمين بقيمة (V0, .) وهو يمثل ارتباط طردي عالي

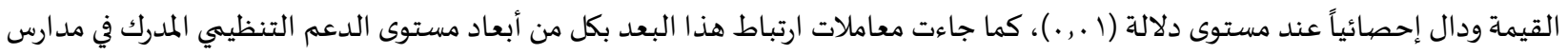

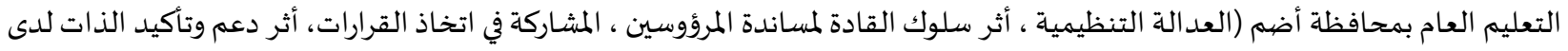

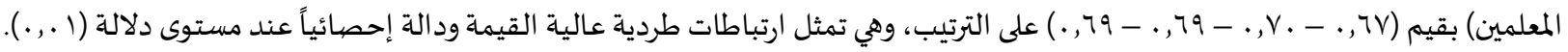

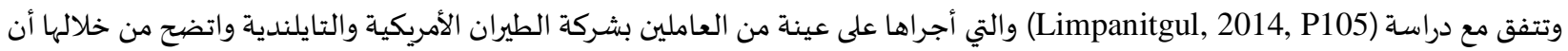

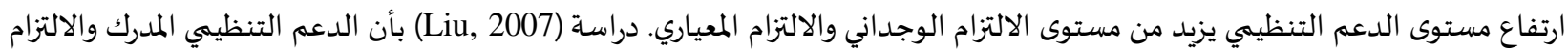
التنظيمي مترابطان بدرجة كبيرة. دراسة (Aube, Rousseau \&Morin, 2007) والتي أظهرت وجود علاقة إيجابية بين الدعم التنظيمي المدرك والالتزام العاطفي. دراسة (Ucar, 2010) من نتائجها وجود علاقة ذات دلالة إحصائية بين الدعم التنظيمي المدرك والالتزام العاطفي دراسة (ريان

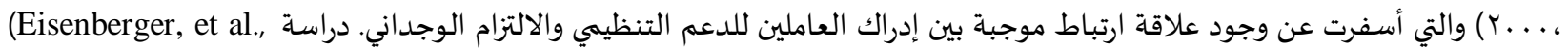

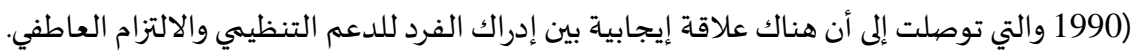

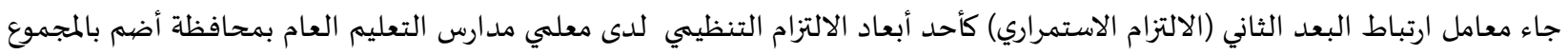

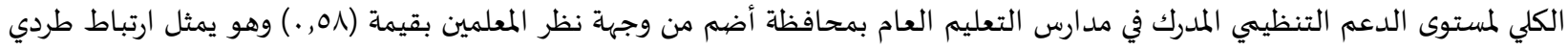
متوسط القيمة ودال إحصائياً عند مستوى دلالة (1 . . .)، كما جاءت معاملات ارتباط هذا البعد بكل من أبعاد مستوى الدعم المعاد التنظيمي المدرك في مدارس التعليم العام بمحافظة أضهم (العدالة التنظيمية ، أثر سلوك القادة لمساندة المرؤوسين ، المشاركة في اتخاذ القرارات، أثر دعم وتأكيد

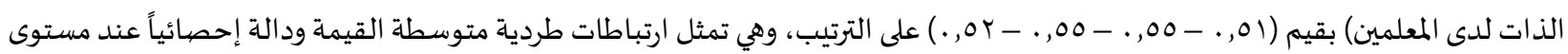
دلالة (1 .,. ..). وتتفق مع دراسـة (Limpanitgul, 2014, P105) والتي كشفت نتائجها عدم وجود تأثير يذكر للدعم التنظيمي على مستوى الالتزام الاستمراري. دراسة (Ucar, 2010) وجود علاقة سلبية بين الدعم التنظيمي المدرك والالتزام الاستمراري. جاء معامل ارتباط البعد الثالث (الالتزام المعياري) كأحد أبعاد الالتزام التنظيمي لدى معلمي مدارس التعليم العام بمحافظة أضم بالمجموع الكلي

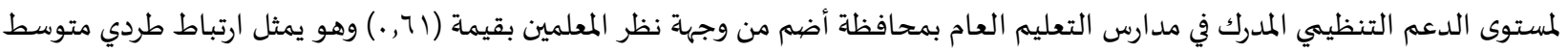

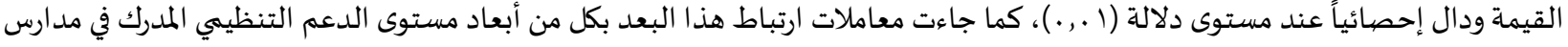

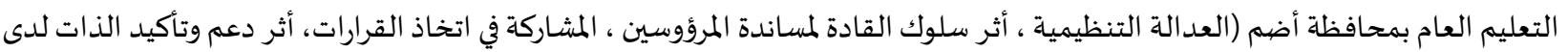

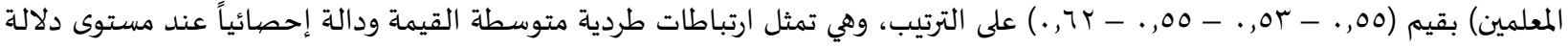

وتتفق مع هذه النتائج كل من دراسة (Erat, Erdil, Eitaoci. 2012) التي استنتجت أن الدعم التنظيمي له تأثير إيجابي على (الالتزام العاطفي الالتزام المعياري) وليس لله تأثير على (الالتزام المعياري). دراسة (Ucar, 2010) من نتائجها وجود علاقة ذانية ذات دلالة إحصيائية بين الدعم التنظيمي المدرك والالتزام المعياري. دراسة (Aube, Rousseau \&Morin, 2007) والتي أظهرت وجود علاقة إيجابية بين الدعم التنظيمي المدرك والالتزام

المعياري.

أوضحت دراسة (Collon \&Davis, 1999) أن هناك علاقة بين النطاق الذي تمارس فيه المعرفة، المعلومات، القوة ودرجة التزام العاملين نحو المنظمة التي يعملون بها. دراسة (Varma, 1999) توصلت إلى أن تفويض الأعمال وتحسين عمليات الإتصال والمشاركة في اتخاذ القرارات

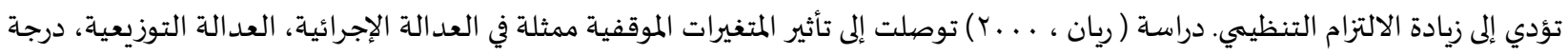

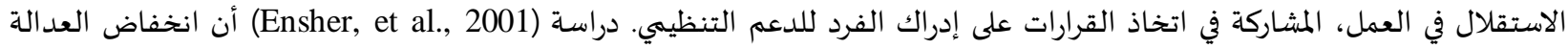

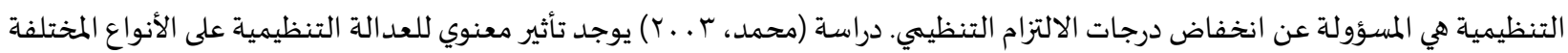
للالتزام التنظيمي.

إجابة السؤال الر ابع: " هل توجد فروق ذات دلالة إحصائية بين متوسطات استجابات معلمي مدارس التعليم العام بمحافظة أضم حول

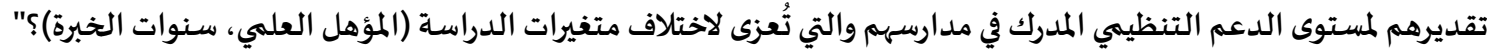

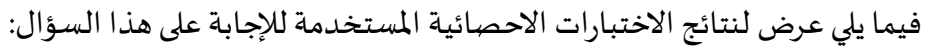
ا. الفروق بين متوسطات استجابات معلمي مدارس التعليم العام بمحافظة أضمى حول تقديرهم لمستوى الدعم التنظيهي المدرك في مدارسهم والتي تعزى لاختلاف المؤهل العلهي : 
تم استخدام الاختبار اللامعلمي (مان ويتني) للتعرف على دلالة ما قد يوجد من فروق بين متوسطات استجابات معلمي مد ارس التعليم العام

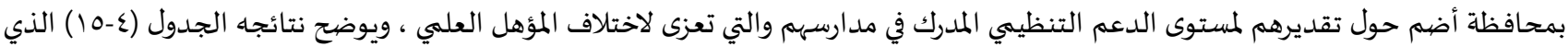
يبين ما يلي:

لا توجد فروق ذات دلالة إحصائية عند مستوى الدلالة (0.,.) بين متوسطات استجابات معلمي مدارس التعليم العام بمحافظة أضم حول

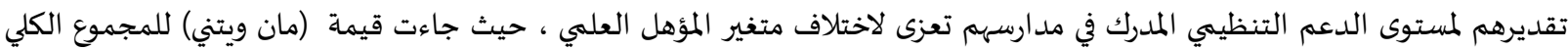

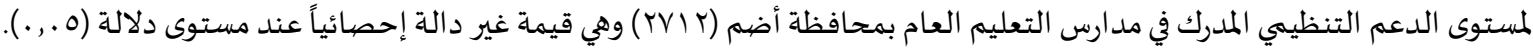
لا توجد فروق ذات دلالة إحصائية عند مستوى الدلالة (0. ,.) بين متوسطات استجابات معلمي مدارس التعليم العام بمحافظة أضمى حول

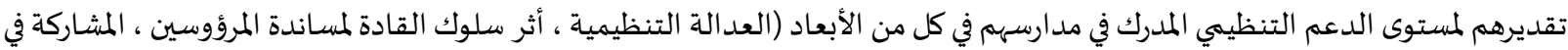

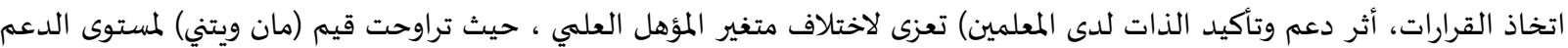

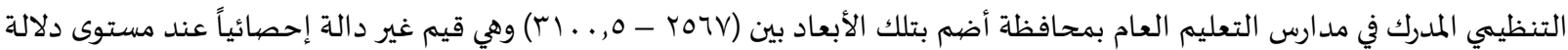

جدول(ع)): نتائج اختبار (مان ويتني) للتعرف على دلالة ما قد يوجد من فروق بين متوسطات استجابات معلمي مدارس التعليم العام بمحافظة أضم حول

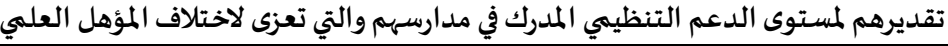

\begin{tabular}{|c|c|c|c|c|c|c|}
\hline مستوى الدلالة & Uيمة مان ويتني & مجموع الرتب & متوسط الرتب & العدد & المؤهل العلمي & المتغيرات \\
\hline \multirow[t]{2}{*}{. } & \multirow[t]{2}{*}{ 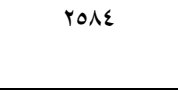 } & rYo人t & $1 \varepsilon \varepsilon, 07$ & r.. & بكالوريوس & \multirow{2}{*}{ البعد الأول : العدالة التنظيمية } \\
\hline & & YMA & Ir.,IV & $r \varepsilon$ & دراسات عليا & \\
\hline \multirow[t]{2}{*}{., 10} & \multirow[t]{2}{*}{ rotr } & rVI.r & $\mid \varepsilon \varepsilon, 7 r$ & r.. & بكالوريوس & \multirow[t]{2}{*}{ البعد الثاني : أثرسلوك القادة لمساندة المرؤوسين } \\
\hline & & rATV & $119, \varepsilon 7$ & $r \varepsilon$ & دراسات عليا & \\
\hline \multirow[t]{2}{*}{. T\& } & \multirow[t]{2}{*}{ ryoo } & $r V \varepsilon 1 \varepsilon, 0$ & $1 \varepsilon r, q$. & r.. & بكالوريوس & \multirow[t]{2}{*}{ البعد الثالث : المشاركة في اتخاذ القرارات } \\
\hline & & $r .00,0$ & $|r v, r|$ & $r \varepsilon$ & 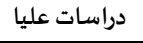 & \\
\hline \multirow[t]{2}{*}{., 97.} & \multirow[t]{2}{*}{$r 1 . ., 0$} & $r v .79,0$ & $\mid \varepsilon Y, 01$ & r.. & بكالوريوس & \multirow[t]{2}{*}{ البعد الر ابع : أثردعم وتأكيد الذات لدى المعلمين } \\
\hline & & $r \varepsilon \ldots, 0$ & $1 \varepsilon 1,79$ & $r \varepsilon$ & دراسات عليا & \\
\hline \multirow[t]{2}{*}{., Ү८9 } & \multirow[t]{2}{*}{ rVIr } & rV乏OA & $1 \varepsilon \varepsilon, \cdot V$ & r.. & بكالوريوس & \multirow{2}{*}{ المجموع الكلي (مستوى الدعم التنظيهي المدرك في مدارس التعليم } \\
\hline & & $r .1 r$ & 1 ro,o. & $r \varepsilon$ & دراسات عليا & \\
\hline
\end{tabular}

ويعتقد الباحث أن سبب عدم الاختلاف بالنسبة لإدراك الدعم التنظيمي لحاملي شهادة البكالوريوس أو الحاصلين على شهادات عليا نتيجة لأههم يشتركون في عمل واحد ومهامهم واحدة وليس هناك اختلاف في درجة الدعم التنظيمي الذي يقدم في مدارس التعليم العام. ويتفق مع نتائج هذه الدراسة دراسة ( ريان، . . ب) والتي أظهرت أن متغيرات الخصائص الشخصية لم تسجل أي تأثير جوهري على إدراك الأفراد للدعم التنظيمي.

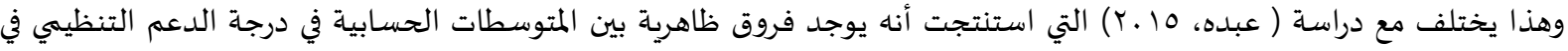

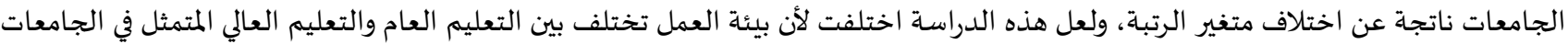

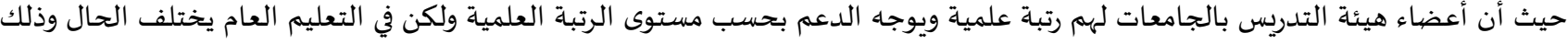

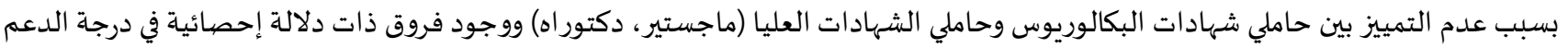

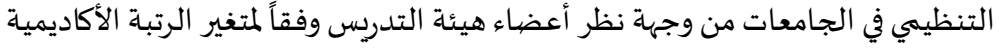
r. الفروق بين متوسطات استجابات معلمي مدارس التعليم العام بمحافظة أضمى حول تقديرهم لمستوى الدعم التنظيمي المدرك في مدارسهمه والتي تعزى لاختلاف سنوات الخبرة:

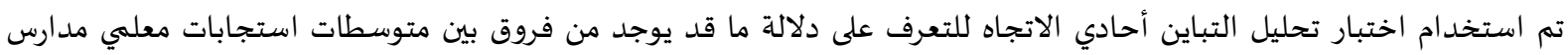
التعليم العام بمحافظة أضم حول تقديرهم لمستوى الدعم التنظيمي المدرك في مدارسهم والتي تعزى لاختلاف سنوات الخبات التبرة ، ويوضح نتائجه الجدول

يتبين من جدول(ro) ما يلي:

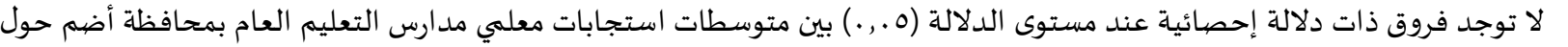

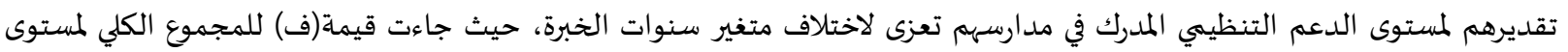
الدعم التنظيمي المدرك في مدارس التعليم العام بمحافظة أضم (إ ( . .) وهي قيمة غير دالة إحصائياً عند مستوى دلالة (ه . . .). 
لا توجد فروق ذات دلالة إحصائية عند مستوى الدلالة (0. . .) بين متوسطات استجابات معلمي مدارس التعليم العام بمحافظة أضم حول تقديرهم لمستوى الدعم التنظيمي المدرك في مدارسهم في كل من الأبعاد (العدالة التنظيمية، أثر سلوك القادة لمساندة المرؤوسين، المشاركة في

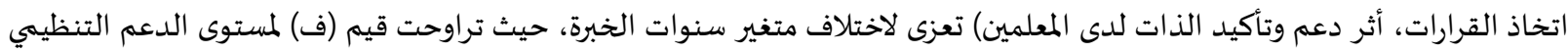

المدرك في مد ارس التعليم العام بمحافظة أضم بتلك الأبعاد بين (V . . . - ع ع ع, . ) وهي قيم غير دالة إحصائياً عند مستوى دلالة (0 . . .).

جدول(Y0): نتائج اختبارتحليل التباين أحادي الاتجاه للتعرف على دلالة ما قد يوجد من فروق بين متوسطات استجابات معلمي مدارس التعليم العام

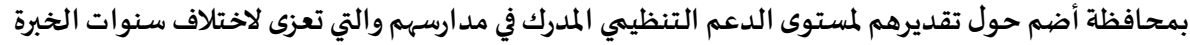

\begin{tabular}{|c|c|c|c|c|c|c|}
\hline الدلالة الإحصيائية & ف & متوسط المربعات & درجات الحرية & مجموع المربعات & مصيادر التباين & المتغيرات \\
\hline \multirow[t]{3}{*}{., 700} & . &., 19 & r & 9 & بين المجموعات & \multirow{3}{*}{ البعد الأول : العدالة التنظيمية } \\
\hline & & $\cdot, \varepsilon 7$ & rAl & $\mid r \Lambda, \wedge O$ & داخل المجمموعات & \\
\hline & & & rat & $\mid r q, Y \varepsilon$ & الكلي & \\
\hline \multirow[t]{3}{*}{$\cdot, 9 V r$} &.,.$Y V$ &.,$\cdot r$ & r & , . r & بين المجموعات & \multirow{3}{*}{ البعد الثاني : أثرسلوك القادة } \\
\hline & & $\cdot, 70$ & rAl & $1 \wedge r, 09$ & داخل المجموعات & \\
\hline & & & rAr & $M Y, T Y$ & 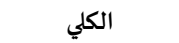 & \\
\hline \multirow[t]{3}{*}{ 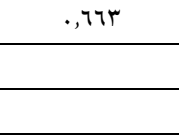 } & $\cdot, \varepsilon \|$ & •, TV & r &., 00 & بين المجموعات & \multirow{3}{*}{ البعد الثالث : المشاركة في اتخاذ } \\
\hline & & $\cdot, 7 \mathrm{~V}$ & rیl & $\mid \wedge V, \varepsilon r$ & داخل المجموعات & \\
\hline & & & rAT & $1 \wedge \vee, 91$ & 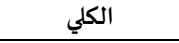 & \\
\hline \multirow[t]{3}{*}{$\cdot, \mathrm{VAV}$} & .,$Y \varepsilon$. &., 1. & r & $\cdot, Y$ & بين المجموعات & \multirow{3}{*}{ البعد الر ابع : أثر دعم وتأكيد الذات } \\
\hline & & $\cdot, \varepsilon r$ & rیI & $|r|, 7$. & داخل المجموعات & \\
\hline & & & rat & $|r|, \Lambda \mid$ & 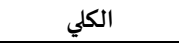 & \\
\hline \multirow[t]{3}{*}{$\cdot, \wedge 11$} &.,$|Y|$ &., .0 & r & $\cdot, 11$ & بين المجموعات & \multirow{3}{*}{ التنظيمي المدرك في مدارس المكلي (مستوى الدعلم } \\
\hline & &., , & rAl & $1 r 7,1$. & داخل المجموعات & \\
\hline & & & rAr & $|r T, r|$ & 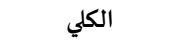 & \\
\hline
\end{tabular}

وهذا يتفق مع دراسة ( عبده، 10 ــ) التي أوضحت بعدم وجود فروق ذات دلالة إحصائية في درجة الدعم التنظيمي في الجامعات الأردنية من وجهة نظر أعضاء هيئة التدريس وفقاً لمتغير سنوات دوات الخبرة.

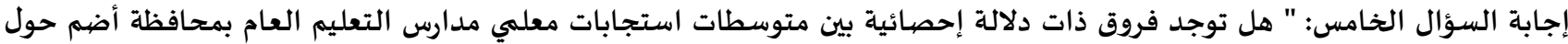

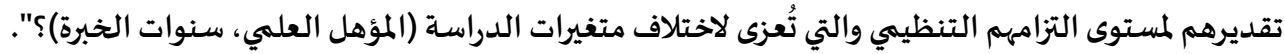
فيما يلي عرض لنتائج الاختبارات الاحصائية المستخدمة للإجابة على هذا السؤال: ا. الفروق بين متوسطات استجابات معلمي مدارس التعليم العام بمحافظة أضيم حول تقديرهم لمستوى الالتزام التنظيهي لديهم والتي تعزى لاختلاف المؤهل العلمي : تم استخدام الاختبار اللامعلمي (مان ويتني) للتعرف على دلالة ما قد يوجد من فروق بين متوسطات استجابات معلمي مدارس التعليم العام

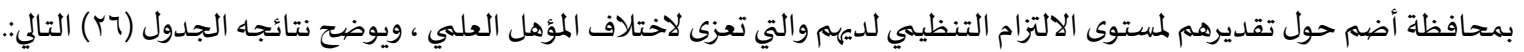
جدول (جr): نتائج اختبار(مان ويتني) للتعرف على دلالة ما قد يوجد من فروق بين متوسطات استجابات معلمي مدارس التعليم العام بمحافظة أضهم حول

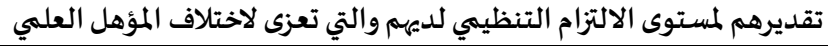

\begin{tabular}{|c|c|c|c|c|c|c|}
\hline مستوى الدلالة & $ت$ & الانحراف المعياري & المتوسط الحسابي & 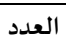 & المؤهل العلمي & المتغيرات \\
\hline \multirow[t]{2}{*}{., V乏A } & \multirow[t]{2}{*}{ r997,0 } & Mา9r & $1 \varepsilon r, . r$ & r.. & بكالوريوس & \multirow[t]{2}{*}{ البعد الأول : الالتزام العاطفي } \\
\hline & & rosr,o & $1 \varepsilon V, 70$ & $T \varepsilon$ & دراسات عليا & \\
\hline \multirow[t]{2}{*}{., V10 } & \multirow[t]{2}{*}{$r .10$} & M৭qย० & $\mid \varepsilon r, 1$. & r. & بكالوريوس & \multirow[t]{2}{*}{ البعد الثاني : الالتزام الاستمراري } \\
\hline & & roro & $\mid \varepsilon 7, \wedge 1$ & $r \varepsilon$ & دراسات عليا & \\
\hline \multirow[t]{2}{*}{. Orr } & \multirow[t]{2}{*}{ YM. } & rrrq. & $1 \varepsilon r, \varepsilon r$ & r.. & بكالوريوس & \multirow[t]{2}{*}{ البعد الثالث : الالتزام المعياري } \\
\hline & & rin. & ITr,o. & $T \varepsilon$ & دراسات عليا & \\
\hline \multirow[t]{2}{*}{., $9 . \varepsilon$} & \multirow[t]{2}{*}{$r \cdot v r, 0$} & $r V .97,0$ & $\mid \varepsilon r, 71$ & rq. & بكالوريوس & \multirow{2}{*}{ التنظيمي لدى معلمي مدارس الكلي (مستوى الالتزام } \\
\hline & & TrVT,o & $1 \varepsilon ., 07$ & $r \varepsilon$ & دراسات عليا & \\
\hline
\end{tabular}


يتبين من جدول (Tr) السابق ما يلي:

لا توجد فروق ذات دلالة إحصائية عند مستوى الدلالة (0. . .) بين متوسطات استجابات معلمي مدارس التعليم العام بمحافظة أضمى حول

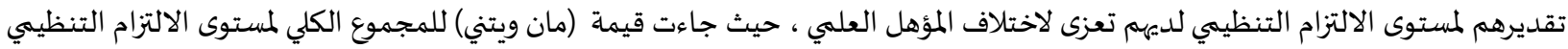

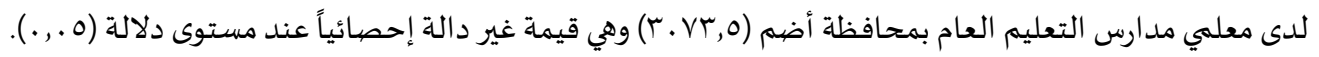
لا توجد فروق ذات دلالة إحصائية عند مستوى الدلالة (0. . .) بين متوسطات استجابات معلمي مدارس التعليم العام بمحافظة أضم حول

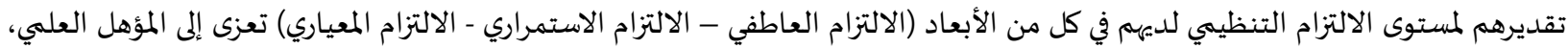

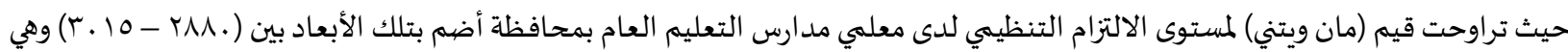

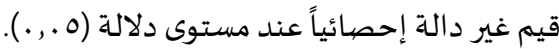

ويعزو الباحث هذه النتيجة إلى أن المؤهل العلمي لها تأثير على مستوى الالتزام التنظيمي لدى المئي المعلمين، ولكنها ليس إلى درجة كبيرة قد تؤثر في الالتزام التنظيمي لدى المعلمين، ففي ظل توفر التقنيات الحديثة يستطيع المعلمين الحاصلين على البكالوريوس اكتساب مهارات وتقنيات جديدة ترفع

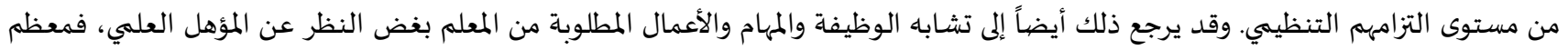

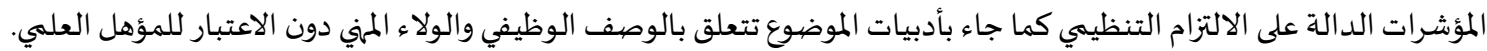

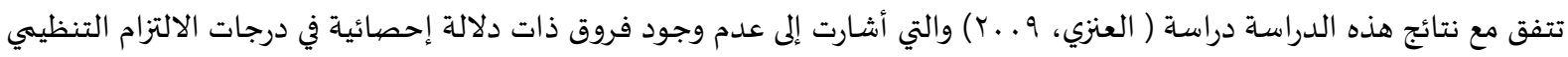

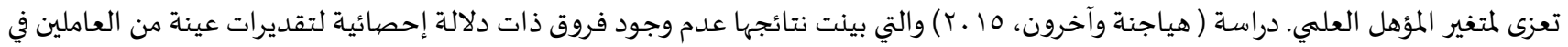

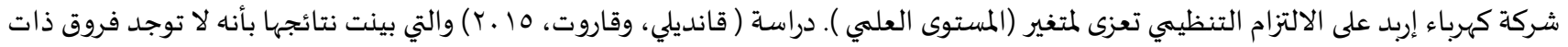

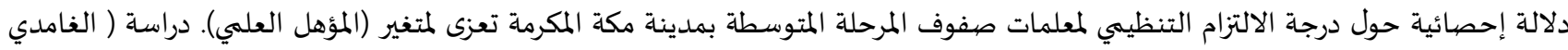

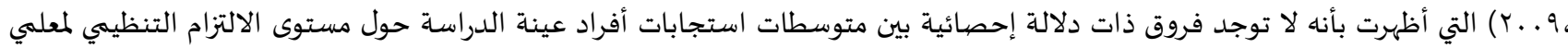
المدارس الثانوية الحكومية بمحافظة جدة من وجهة نظرهم تعزى لمتخير نوع المؤهل.

تختلف مع نتائج هذه الدراسة دراسة (Mathieu \&Zajac, 1990) التي أظهرت أن المستوى التعليمي يؤثر تأثيراً عكسياً على الالتزام

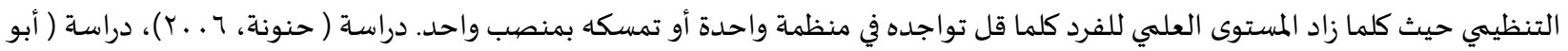

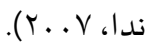

r. الفروق بين متوسطات استجابات معلمي مدارس التعليم العام بمحافظة أضم حول تقديرهم لمستوى الالتزام التنظيهي لديهم والتي تعزى لاختلاف سنوات الخبرة : بون بوسن

تم استخدام اختبار تحليل التباين أحادي الاتجاه للتعرف على دلالة ما قد يوجد من فروق بين متوسطات استجابات معلمي مدارس

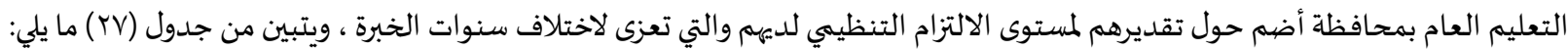
لا توجد فروق ذات دلالة إحصائية عند مستوى الدلالة (0. . •) بين متوسطات استجابات معلمي مدارس التعليم العام بمحافظة أضم حول

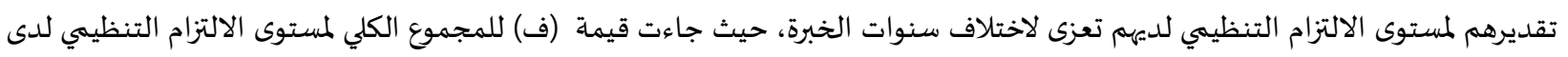
معلمي مد ارس التعليم العام بمحافظة أضهم (VOY, . .) وهي قيمة غير دالة إحصيائياً عند مستوى دلالة (0. . . .). لا توجد فروق ذات دلالة إحصائية عند مستوى الدلالة (0. . •) بين متوسطات استجابات معلمي مدارس التعليم العام بمحافظة أضم حول

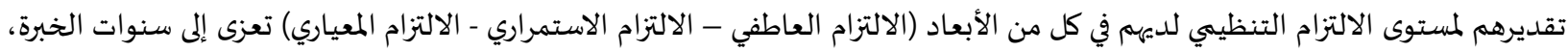

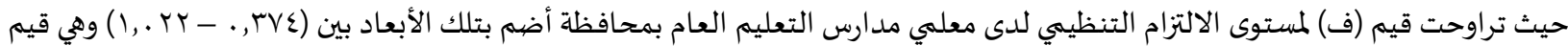
غير دالة إحصائياً عند مستوى دلالة (0. . . .). 
جدول (YV): نتائج اختبارتحليل التباين أحادي الاتجاه للتعرف على دلالة ما قد يوجد من فروق بين متوسطات استجابات معلمي مدارس التعليم العام

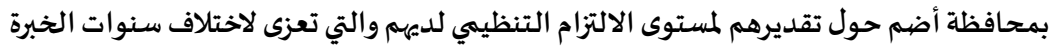

\begin{tabular}{|c|c|c|c|c|c|c|}
\hline الدلالة الإحصائية & ف & متوسط المربعات & درجات الحرية & مجموع المربعات & مصبادر التباين & المتغيرات \\
\hline \multirow[t]{3}{*}{., זาו } & $1, . r Y$ & ., vo & $r$ & 1,0 & بين المجموعات & \multirow[t]{3}{*}{ البعد الأول : الالتزام العاطفي } \\
\hline & &.,$v r$ & rMl & $r .0,71$ & داخل المجمموعات & \\
\hline & & & rAT & $r \cdot v, 11$ & الكلي & \\
\hline \multirow[t]{3}{*}{.,$\varepsilon V \pi$} &., Vo. &., 7. & r & $1, r$ & بين المجموعات & \multirow[t]{3}{*}{ البعد الثاني : الالتزام الاستمراري } \\
\hline & & $\cdot, \Lambda$. & YNI & $r Y \varepsilon, \cdot \varepsilon$ & داخل المجموعات & \\
\hline & & & rAr & rYO,YE & 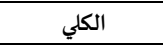 & \\
\hline \multirow[t]{3}{*}{., $7 \wedge 1$} & . TV &., $\mathrm{YM}$ & $r$ &., 07 & بين المجموعات & \multirow[t]{3}{*}{ البعد الثالث : الالتزام المعياري } \\
\hline & & ., vo & rAl & rII,Tr & داخل المجمموعات & \\
\hline & & & rAT & $r M, \wedge$ & 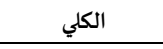 & \\
\hline \multirow[t]{3}{*}{.,$\varepsilon \vee r$} & .,vor & $\cdot, \varepsilon \wedge$ & $r$ &., 97 & بين المجموعات & \multirow{3}{*}{ 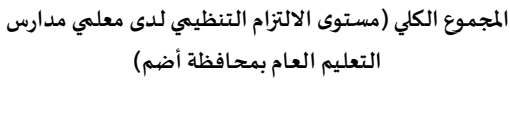 } \\
\hline & &., $7 \varepsilon$ & rAl & $1 v 9, .1$ & داخل المجموعات & \\
\hline & & & thr & 189,97 & 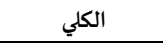 & \\
\hline
\end{tabular}

ويعزو الباحث هذه النتائج إلى أن سنوات الخبرة ليس لها أي تأثير في الالتزام التنظيمي إلى أن المعلم حتى لو كانت فترة خدمته في التعليم كبيرة

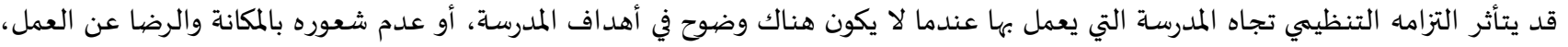
وكذلك لا يهيأ له المناخ المشجع على العمل، وغيرها من الأسباب التي تدفح إلى انخفاض في الالتزام التنظيمي لدى أي معلم. وإضافة على ذلك فئك فالمعلم

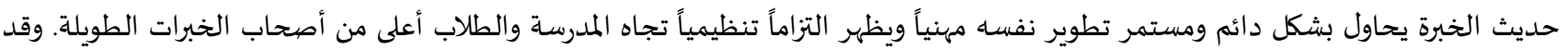
يرجع أيضاً لشعور المعلمين بالاستقرار الوظيفي

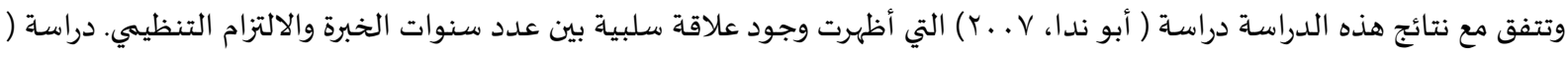

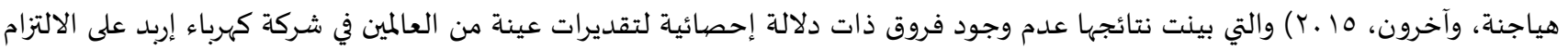
التنظيمي تعزى لمتغير (سنوات الخدمة ). دراسة ( قانديلي، وقاروت، 10 ـ1) والتي بينت نتائجها بأنه لا توجد فروق ذات دلالة إحصيائية حول درجة

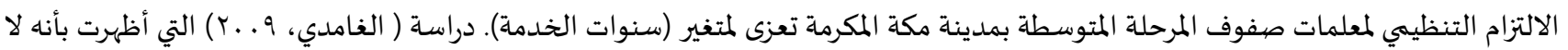
توجد فروق ذات دلالة إحصائية بين متوسطات استجابات أفراد عينة الدراسة حول مستوى الالتزام التنظيمي لمعلمي المدارس الثانوية الحكومية

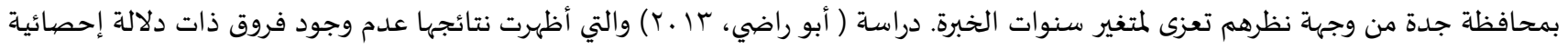
عند مستوى (0 . . .) في مستوى الالتزام التنظيمي لمعلمي المدارس الخاصة ومعلماتها في محافظة عمّان تبعاً لمتغير الخبرة. وتختلف مع نتائج هذه الدراسة دراسة ( محمد، ب ... التي أظهرت وجود علاقة ارتباط ذات دلالة إحصائية مدة الخدمة والالتزام التنظيمي. وتختلف مع نتائج هذه الدراسة دراسة (Maeyer \&Allen, 1984) والتي استنتجت أن الأفراد الأكبر سناً هم أكثر إلتزاماً ومحافظة على دوالى الالتزام

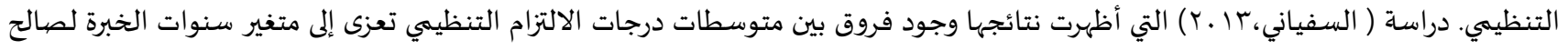
تقدير المعلمين الأقل خبرة مقابل الأعلى خبرة. دراسة هوليبا وديفوس وفان كير (Hulipa, Devos, \&Van Keer, 2010) والتي كشفت التهات نتائجها بأن

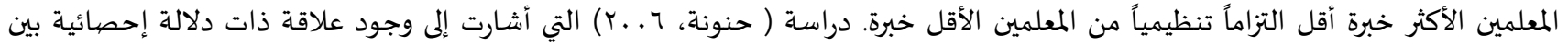

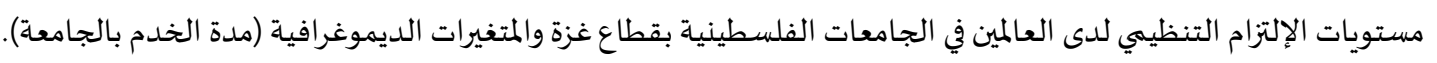
ملخص النتائج والتوصيات: بعد أن عرض الباحث في الفصل السابق نتائج الدراسة الميدانية وذلك من خلال عرض استجابات أفراد عينة الدراسة على تساؤلات الدراسـة ومعالجتها إحصائياً باستخدام مفاهيم الإحصاء الوصفي وأساليبه الإحصائية وصولاً إلى النتائج وتحليلها وتفسيرها. يتناول هذا الفصل ملخص نتائج الدراسة الميدانية، وينتهي بتقديم التوصيات والبحوث المقترحة. أولاًا : ملخص النتائج:

ويتمثل ذلك في عرض أبرز النتائج التي توصلت إلهها الدراسة فيما يتعلق بالإجابة على تساؤلاتها وتحقيق أهدافها، على النحو التالي:

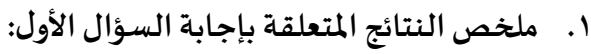
استهدف هذا السؤال التعرف على مستوى الدعم التنظيمي المدرك لدى ملئه معلمي مدارس التعليم العام بمحافظة أضمى من وجهة نظر المعلمين أنفسهم، وكانت أبرز النتائج ما يلي:

أن مستوى الدعم التنظيمي المدرك في مدارس التعليم العام بمحافظة أضهم جاء بدرجة (كبيرة) من وجهة نظر المعلمين. أن مستوى الدعم التنظيمي المدرك في مدارس التعليم العام بمحافظة أضهم في بعد (أثر دعم وتأكيد الذات لدى المعلمين) جاء في الترتيب الأول، يليه في الترتيب الثاني مستوى الدعم التنظيمي المدرك في بعد (أثر سلوك القادة لمساندة المرؤوسين)، ثم في الترتيب الثالث جاء مستوى 
الدعم التنظيمي المدرك في بعد (المشاركة في اتخاذ القرارات) وفي الترتيب الأخير جاء مستوى الدعم التنظيمي المدرك في بعد (العدالة

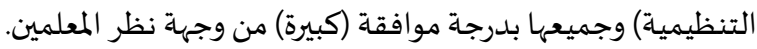

أن مستوى العدالة التنظيمية كأحد أبعاد الدعم التنظيمي المدرك في مدارس التعليم العام بمحافظة أضمى جاء بدرجة (كبيرة) من وجهاة نظر المعلمين وجاءت (عدالة التعاملات) كأحد أبعاد مستوى العدالة التنظيمية في مدارس التعليم العام بمحافظة أضم في الترتيب الأول، يليها في الترتيب الثاني مستوى العدالة التنظيمية في بعد (عدالة الإجراءات) ، وفي الترتيب الأخير جاء مستوى العدالة التنظيمية في بعد (عدالة التوزيعات) وجميعها بدرجة موافقة (كبيرة) من وجهة نظر المعلمين.

أن مستوى عدالة التوزيعات كأحد أبعاد العدالة التنظيمية في مدارس التعليم العام بمحافظة أضهم جاء بدرجة (كبيرة) من وجهة نظر المعلمين، وكانت أبرز العوامل الدالة على مستوى عدالة التوزيعات كأحد أبعاد العدالة التنظيمية في مدارس التعليم العام بمحافظة أضمى التهاء

\section{تكلفني إدارة المدرسة بعمل يتناسب مع قدراتي، بدرجة موافقة (كبيرة) \\ تتناسب ساعات العمل مع ظروفي الخاصية، بدرجة موافقة (كبيرة).}

أن مستوى عدالة الإجراءات كأحد أبعاد العدالة التنظيمية في مدارس التعليم العام بمحافظة أضمى جاء بدرجة (كبيرة) من وجهة نظر

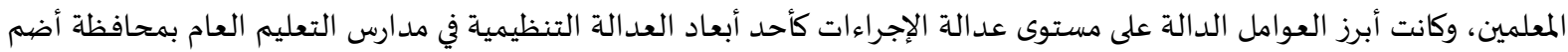

$$
\text { أستطيع الاعتراض على القرارات التي تصدر ضدي، بدرجة موافقة (كبيرة) }
$$

تطبق إدارة المدرسة اللوائح والتعليمات بطريقة عادلة، بدرجة موافقة (كبيرة).

أن مستوى عدالة التعاملات كأحد أبعاد العدالة التنظيمية في مدارس التعليم العام بمحافظة أضم جاء بدرجة (كبيرة) من وجهة نظر المعلمين ، وكانت أبرز العوامل الدالة على مستوى عدالة التعاملات كأحد أبعاد العدالة التنظيمية في مدارس التعليم العام بمحافظة أضم

يتسم حل الخلافات بين العاملين في المدرسة بالنزاهة، بدرجة موافقة (كبيرة)

تناقشني إدارة المدرسة في النتائج عندما تتخذ أي قرارٍ يتعلق بوظيفتي، بدرجة موافقة (كبيرة).

أن مستوى أثر سلوك القادة لمساندة المرؤوسين كأحد أبعاد الدعم التنظيمي المدرك في مدارس التعليم العام بمحافظة أضم جاء بدرجة (كبيرة) من وجهة نظر المعلمين ، وكانت أبرز العوامل الدالة على مستوى أثر سلوك القادة لمساندة المرؤوسين كأحد أبعاد الدعم التنظيمي

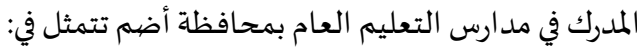

يبادر قائد المدرسة لمساعدتي عندما أواجاء أي مشكلة في العمل، بدرجة موافقة (كبيرة جداً) يشجع قائد المدرسة روح التعاون بين المعلمين، بدرجة موافقة (كبيرة). أن مستوى المشاركة في اتخاذ القرارات كأحد أبعاد الدعم التنظيمي المدرك في مدارس التعليم العام بمحافظة أضمى جاء بدرجة (كبيرة) من وجهاة نظر المعلمين ، وكانت أبرز العوامل الدالة على مستوى المشاركة في اتخاذ القرارات كأحد أبعاد الدعم التنظيمي المدرك في مدارس التعليم العام بمحافظة أضمى تتمثل في: وانه

أشـارك بقدر كبير في القرارات المرتبطة بتخصصي وواجباتي الوظيفية، بدرجة موافقة (كبيرة)

$$
\text { تراعي إدارة المدرسة مصلحتي ذات العلاقة بعملي، بدرجة موافقة (كبيرة). }
$$

أن مستوى أثر دعم وتأكيد الذات لدى المعلمين كأحد أبعاد الدعم التنظيمي المدرك في مدارس التعليم العام بمحافظة أضمى جاء بدرجة (كبيرة) من وجهة نظر المعلمين ، وكانت أبرز العوامل الدالة على مستوى أثر دعم وتأكيد الذات لدى المعلمين كأحد أبعاد الدعم التنظيمي

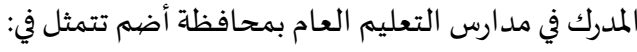

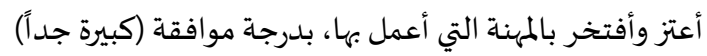

يساعدني الاستقرار في عملي على الإبداع بشكل مستمر، بدرجة موافقة (كبيرة جداً).

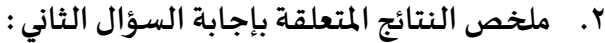

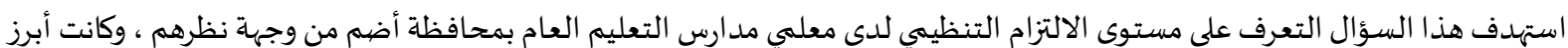

النتائج ما يلي

أن مستوى الالتزام التنظيمي لدى معلمي المدارس الثانوية بمحافظة جدة جاء بدرجة (كبيرة) من وجهة نظرهم. 
أن مستوى الالتزام التنظيمي لدى معلمي مدارس التعليم العام بمحافظة أضم في بعد (الالتزام العاطفي) جاء في الترتيب الأول يليه في الترتيب الثاني مستوى الالتزام التنظيمي في بعد (الالتزام المعياري)، ثم في الترتيب الثالث جاء مستوى الالتزام التنظيمي في بعد (الالتزام الاستمراري)

وجميعها بدرجة (كبيرة)

أن مستوى (الالتزام العاطفي) كأحد أبعاد الالتزام التنظيمي لدى معلمي مدارس التعليم العام بمحافظة أضمى جاء بدرجة (كبيرة) من وجهة

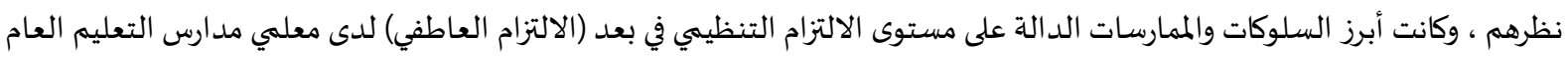

بمحافظة أضهم تتمثل في:

أشعر أنني فرد من أفراد العائلة في هذه المدرسة، بدرجة موافقة (كبيرة)

تعني لي مدرستي الكثير بشكل شخصي، بدرجة موافقة (كبيرة).

أن مستوى (الالتزام الاستمراري) كأحد أبعاد الالتزام التنظيمي لدى معلمي مدارس التعليم العام بمحافظة أضمى جاء بدرجة بداء (كبيرة) من

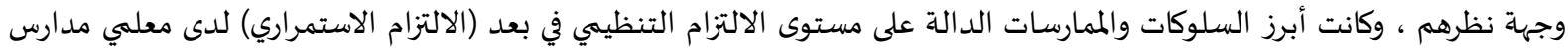

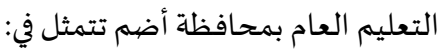

يعكس عملي في المدرسة ضرورة حاجتي للعمل أكثر من رغبتي فيه، بدرجة موافقة (كبيرة)

يصعب عليّ ترك المدرسة التي أعمل بها حالياً، بدرجة موافقة (كبيرة).

أن مستوى (الالتزام المعياري) كأحد أبعاد الالتزام التنظيمي لدى معلمي مدارس التعليم العام بمحافظة أضم جاء بدرجة (كبيرة) من وجهاة

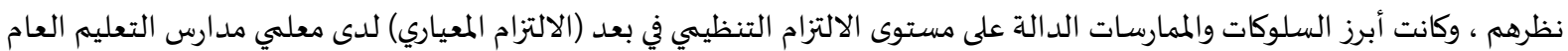

بمحافظة أضهم تتمثل في:

• تستحق المدرسة التي أعمل بها إخلاصي لها، بدرجة موافقة (كبيرة جداً)

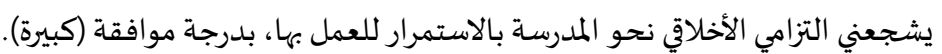

r. ملخص النتائج المتعلقة بإجابة السؤال الثالث:

استهدف هذا السؤال التعرف على مدى وجود علاقة ارتباطيه ذات دلالة إحصائية بين مستوى الدعم التنظيهي كما يدركه المعلمون بمدارس التعليم

العام بمحافظة أضم بسلوك الالتزام التنظيمي لديهم ، وكانت أبرز النتائج ما يلي:

توجد علاقة ارتباطية (طردية) عالية القيمة وذات دلالة إحصائية عند مستوى دلالة (1 . . .) بين مستوى الدعم التنظيمي المدرك في مدارس التس

التعليم العام بمحافظة أضمى ومستوى الالتزام التنظيمي لدى المعلمين.

توجد علاقة ارتباطية (طردية) متوسطة القيمة وذات دلالة إحصائية عند مستوى دلالة (1 . ..) بين جميع الأبعاد الداخلية لمستوى الالتزام

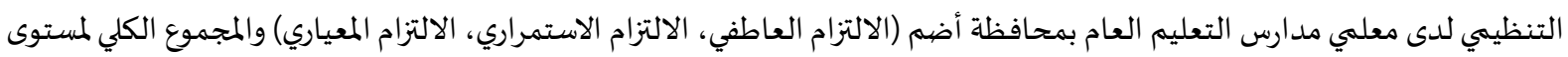

الدعم التنظيمي المدرك بمدارس التعليم العام بمحافظة أضيم

ع. ملخص النتائج المتعلقة بإجابة السؤال الر ابع :

استهدف هذا السؤال الكشف عن الفروق ذات الدلالة الإحصائية بين متوسطات استحابـابات معلمي مدارس التعليم العام بمحافظة أضم

حول تقديرهم لمستوى الدعم التنظيمي المدرك في مدارسهم والتي تُعزى لاختلاف متغيرات الدراسة (المؤهل العلمي، سنوات المات الخبرة)، وكانت أبرز النتائج

ما يلي:

لا توجد فروق ذات دلالة إحصائية عند مستوى الدلالة (0., .) بين متوسطات استجابات معلمي مدارس التعليم العام بمحافظة أضمى حول

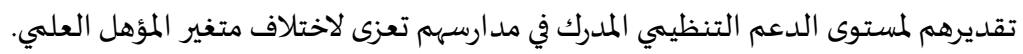

لا توجد فروق ذات دلالة إحصائية عند مستوى الدلالة (0. ..) بين متوسطات استجابات معلمي مدارس التعليم العام بمحافظة أضمى حول تقديرهم لمستوى الدعم التنظيمي المدرك في مدارسهم في كل من الأبعاد (العدالة التنظيمية، أثر سلوك القادة لمساندة المرؤوسين، المشاركة في

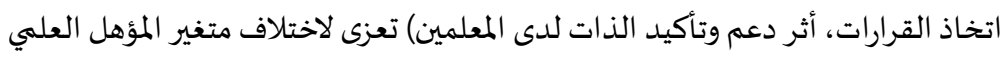

لا توجد فروق ذات دلالة إحصائية عند مستوى الدلالة (0. ..) بين متوسطات استجابات معلمي مدارس التعليم العام بمحافظة أضمى حول

تقديرهم لمستوى الدعم التنظيمي المدرك في مدارسهم تعزى لاختلاف متغير سنوات دورات الخبرة

لا توجد فروق ذات دلالة إحصائية عند مستوى الدلالة (0., .) بين متوسطات استجابات معلمي مدارس التعليم العام بمحافظة أضهم حول تقديرهم لمستوى الدعم التنظيمي المدرك في مدارسهم في كل من الأبعاد (العدالة التنظيمية، أثر سلوك القادة لمساندة المرؤوسين، المشاركة في

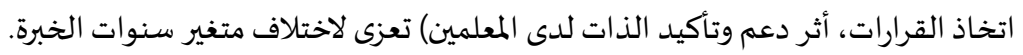


0. ملخص النتائج المتعلقة بإجابة السؤال الخامس:

استهدف هذا السؤال الكشف عن الفروق ذات الدلالة الإحصائية بين متوسطات استجابات معلمي مدارس التعليم العام بمحافظة أضمى

حول تقديرهم لمستوى التزامهم التنظيمي والتي تُعزى لاختلاف متغيرات الدراسة (المؤهل العلمي، سنوات الخبرة)، وكانت أبرز النتائج ما يلي: لا توجد فروق ذات دلالة إحصائية عند مستوى الدلالة (0.. ..) بين متوسطات استجابات معلمي مدارس التعليم العام بمحافظة أضم حول

تقديرهم لمستوى الالتزام التنظيمي لديهم تعزى لاختلاف المؤهل العلهي.

لا توجد فروق ذات دلالة إحصائية عند مستوى الدلالة (ه., .) بين متوسطات استجابات معلمي مدارس التعليم العام بمحافظة أضمى حول

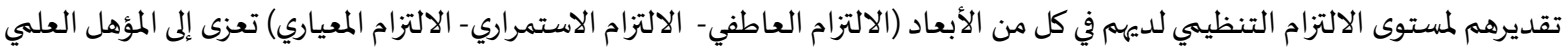
لا توجد فروق ذات دلالة إحصائية عند مستوى الدلالة (0., .) بين متوسطات استجابات معلمي مدارس التعليم العام بمحافظة أضمى حول

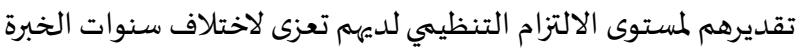
لا توجد فروق ذات دلالة إحصائية عند مستوى الدلالة (0...) بين متوسطات استجابات معلمي مدارس التعليم العام بمحافظة أضم حول تقديرهم لمستوى الالتزام التنظيمي لديهم في كل من الأبعاد (الالتزام العاطفي- الالتزام الاستمراري- الالتزام المعياري) تعزى إلى سنوات التهات الخبرة. ثانياً: توصيات الدراسـة:

في ضوء أدبيات الدراسة ونتائجها الميدانية وخبرة الباحث بالميدان، يمكن وضع مجموعة من التوصيات والمقترحات التي يمكن من خلالها أن تسهم في تطوير وسائل إدراك الدعم التنظيمي لتنمية الالتزام التنظيمي، وهذه التوصيات كما يلي: ا. تعزيز الدعم التنظيمي المدرك لدى معلمي مدارس التعليم العام من خلال الآتي:

ضرورة منح المعلمين الدعم اللازم وقياس مدى إدراكهم لهذا الدعم، كون الدعم التنظيمي لله أثر دال في الالتزام التنظيمي. ضرورة النظر إلى مهنة التعليم والعاملين بها بأها الأساس لتحقق الوزارة بشكل عام والمدارس بشكل خاص أهدافها وتطلعاتها، مما يستوجب بذل المزيد من الجهود التي توفر للمعلمين كل أنواع الدعم التي تسد احتياجاتهم المختلفة. ضرورة أن تنظر إدارات المدارس إلى أن الدعم الذي تقدمه للمعلمين هو استثمار بعيد المدى بدلاً من النظرة التقليدية التي تعتبر هذه الأشكال من الدعم بأنها تكاليف ترهق إدارات المدارس.

يوصي الباحث بأهمية أن تُشعِر المؤسسات التعليمية معلميها بالأمان الوظيفي، وتمنحهم الاستقرار الوظيفي، وأن تعمل على تشجيعهم

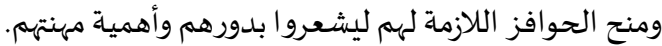
الاستفادة من بعض التجارب العالمية في مجال تقديم الدعم التنظيمي للمعلمين مما سيسهم في زيادة التزامهم التنظيمي وكل ذلك سيكون له نتائج عكسية على المؤسسات التربوية

جعل مهنة التعليم مهنة تنافسية قياساً إلى المهن والوظائف الأخرى، وذلك من خلال تعزيز الحوافز المادية والمزايا المعنوية للمعلمين. تكثيف الخبرات والمضامين التي تغرس وتنمي الاتجاهات الإيجابية تجاه مهنة التعليم، وإشاعة ثقافة وقيم الالتزام التنظيمي لدى المعلمين من خلال اللقاءات والبرامج المصيممة لتحقيق ذلك. r. تحديد العوال التي تساعد على تنمية وتعزيز الالتزام التنظيمي لمعلمي مدارس التعليم العام من خلال: تعزيز الجهود التي تبذلها وزارة التعليم بتحفيزهم ومراجعة الأنظمة الخاصة بمعلميها واشباع حاجاتهم الوظيفية. الاهتمام بآراء المعلمين وعدم تجاهل مطالبهم وحقوقهم، وتوسيع قاعدة المشاركة في صنع القرارات، وتوسيع الممارسات الديموقراطية، والشورية بشكل أكبر، وذلك بغرض رفع مستوى الالتزام التنظيمي لدى واء المعلمين.

ثالثاً : البحوث والدراسات المقترحة:

إعد اد تصور مقترح حول سبل تعزيز الدعم التنظيمي للمعلمين في مدارس التعليم العام.

القيام بدراسة حول الدعم التنظيمي المدرك وعلاقته بمتغيرات مختلفة مثل ( الأنماط القيادية، سلوك المواطنة التنظيمية، المناخ

التنظيمي، الثقافة التنظيمياة) وغيرها. الالتزام التنظيمي لدى قائدي وقائدات مدارس التعليم العام بمحافظة أضمه.

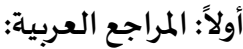

1. ابن منظور، (11 ـ إم) لسان العرب، القاهرة، دار المعارف. 
r. أبو تايه، بندر، (r ا ـr) أثر العدالة التنظيمية على سلوك المواطنة التنظيمية في مراكز الوزارات الحكومية في الأردن، مجلة الجامعة الإسلامية للدراسات الاقتصيادية والإدارية، العدد الثاني. r. أبو جاسر، صابرين، (.1.ب) أثر إدراك العاملين للعدالة التنظيمية على الأداء السياقي: دراسة تطبيقية على موظفي وزارات السلطة الفلسطينية، رسالة ماجستير غير منشورة، الجامعة الإسلامياة. غزة. ع. أبو دهيم، نجاة إبراهيم، (1 ا ـ ( دور ممارسات إدارة الموارد البشرية في تحقيق العدالة التنظيمية: من وجهة نظر رؤساء الأقسام في الوزارات الأردنية، رسالة ماجستير غير منشورة، كلية الأعمال، الجامعة الأردنية، الأردن.

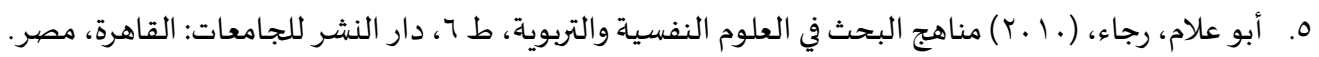

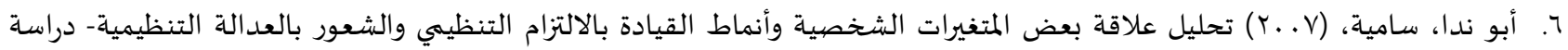

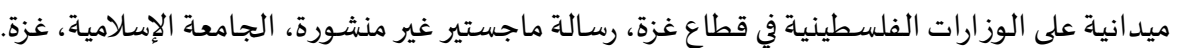

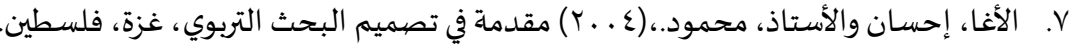

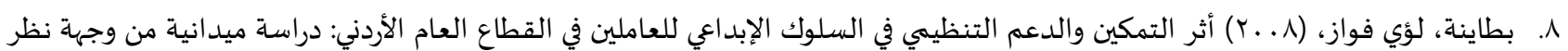
مديري المديريات الحكومية في اقليم الشمال، رسالة ماجستير غير منشورة، كلية الاقتصاد والعلوم الادارية، جامعة اليرموك، الأردن.

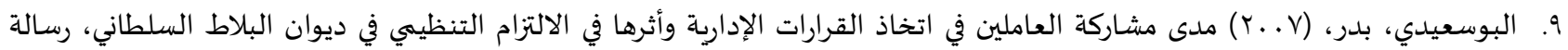
ماجستير غير منشورة، جامعة مؤتة، الأردن.

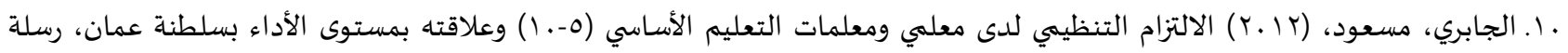
ماجستير غير منشورة، قسم الأصيول والإدارة التربوية، جامعة مؤتة، عمان.

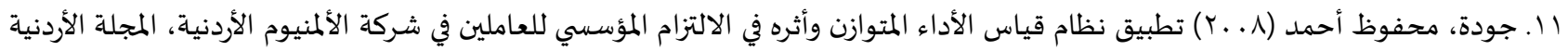

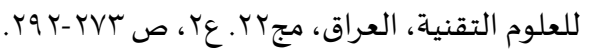

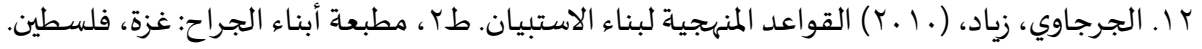

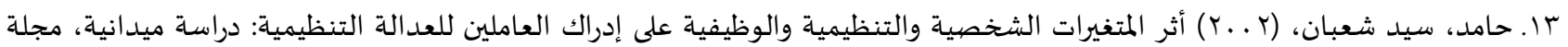
المحاسبة والإدارة والتأمين، العدد اء؛، جهاز الدراسات العليا والبحوث، كلية التجارة، جامعة القاهرة.

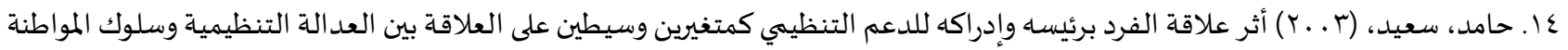
التنظيمياة- دراسة ميد انية. كلية التجارة، جامعة الأزهر. ا. حسن، نهلة سيد، (با ـ بم) تمكين معلمي مدارس الثانوي العام بمحافظة القاهرة الكبرى لتحقيق التزامهم التنظيهي: دراسة ميدانية، مجلة

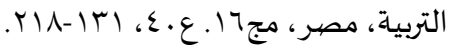

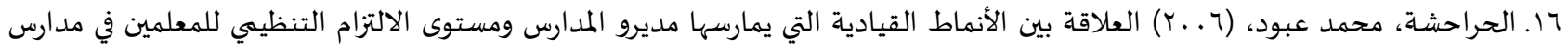

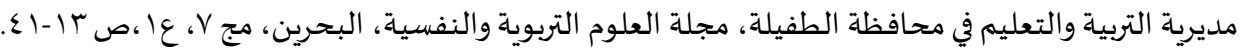

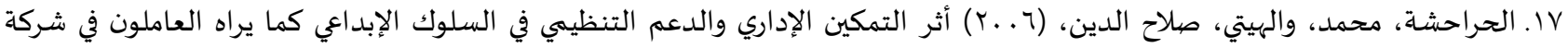

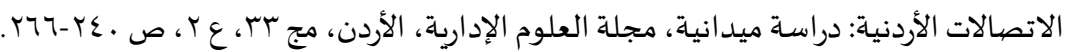

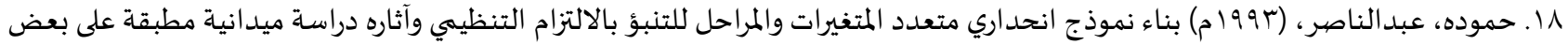

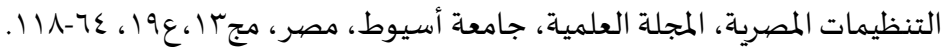

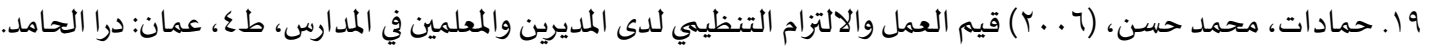

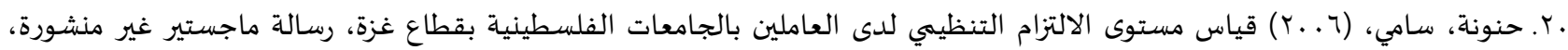
الجامعة الإسلامية، غزة. ا ـ. الخشالي، شاكر جارالله، (r . . r) أثر الأنماط القيادية لرؤساء الأقسام العلمية على الولاء التنظيمي لأعضاء هيئة التدردس في الجامعات الأردنية

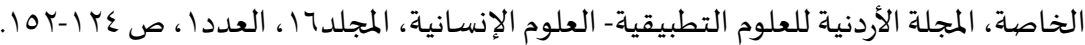

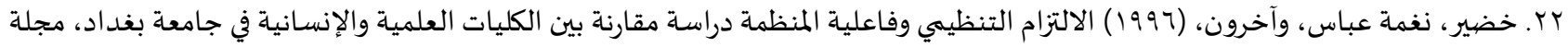

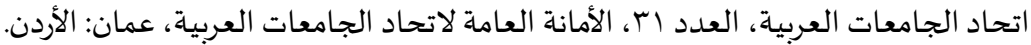

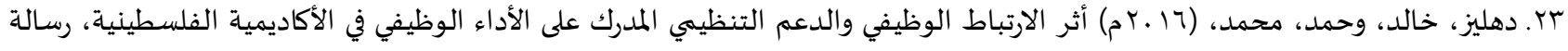

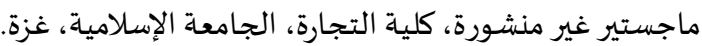


ع r. ذيب، محمد رشـدي، والسعود، راتب، (ع ا ـ ) درجة ممارسة قيم العمل لدى مديري التربية والتعليم في الأردن وعلاقتاه بدرجة الالتزام التنظيمي

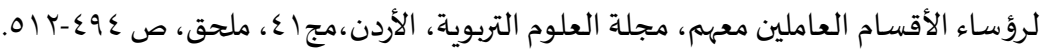

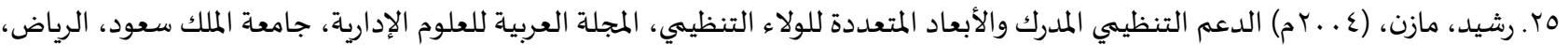

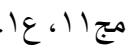
جr. ريان، عادل ريان محمد، ( . . ب) أثر إدراك الأفراد للدعم التنظيمي كمتغير وسيط على العلاقة بين الالتزام التنظيمي الوجداني وبعض المتغيرات

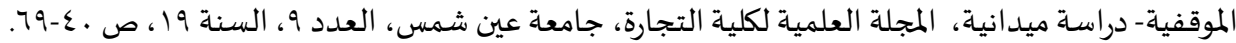
rV زايد، عادل محمد، (1990) تحليل العلاقة بين أساليب مراقبة الأداء الوظيفي وإحساس العاملين بالعدالة التنظيمية، المجلة دراسلة العربية للعلوم

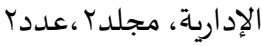

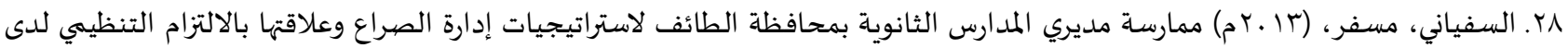
المعلمين، رسالة ماجستير غير منشورة، جامعة أم القرى، مكة المكرمة، السعودية.

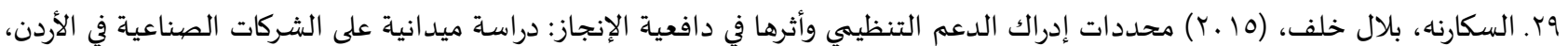

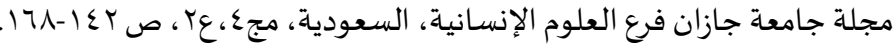

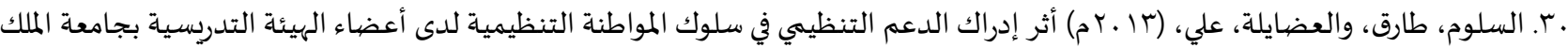

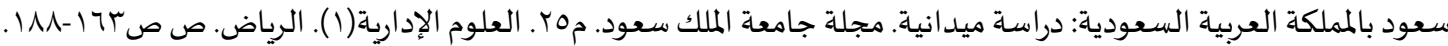

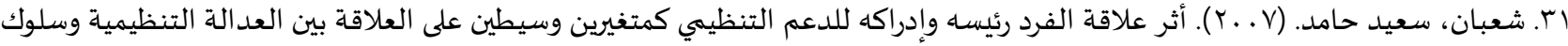

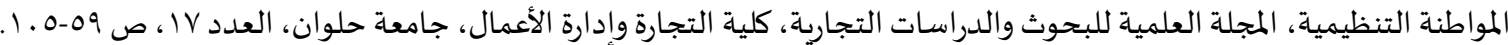

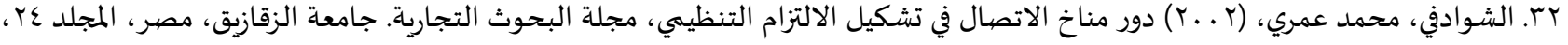
العدد ا، ص .0Y-YqY. rr. الشعلان، مضاوي، (ع ا ـr م) الدعم التنظيمي المدرك لدوافع العمل لدى الموظفات الإداريات بكلية الآداب بجامعة الأميرة نورة بنت عبدالرحمن

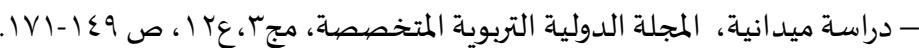

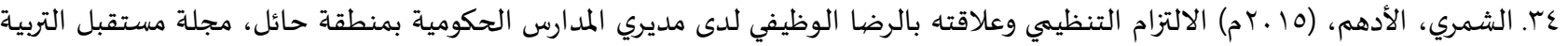

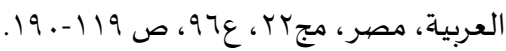

هץ. الشنطي، محمود، (0 إبم) دور الدعم التنظيمي المدرك كمتغير وسيط في العلاقة بين العدالة التنظيمية وسلوك المواطنة التنظيمية (دراسة

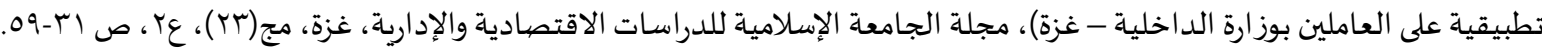
جr. شهاب، فادية إبراهيم، (1 (1) التطوير التنظيمي: القواعد النظرية والممارسات التطبيقية، عمان: الأكاديميون للنشر والتوزيع.

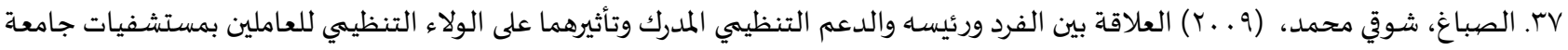

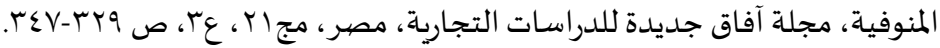

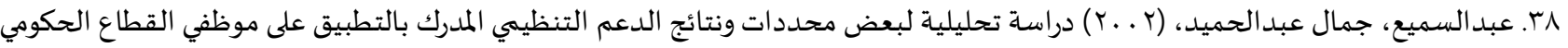

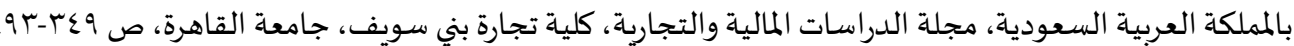

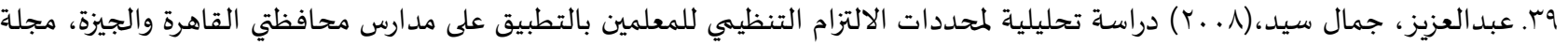

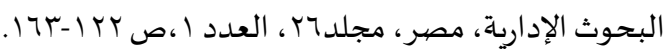
•ع. عبده، نور عدنان،(0) • ام) درجة الدعم التنظيمي وعلاقتها بمستوى الثقة التنظيمية في الجامعات الأردنية، رسالة ماجستير غير منشورة، عمادة البحث العلمي والدراسات العليا، الجامعة الهاشمية، الأردن. اء. عبيدات، ذوقان وعدس، عبدالرحمن، وعبدالحق، كايد، (1 . ب) البحث العلمي- مفهومه وأدواته وأساليبه، دار الفكر للنشر والتوزيع: عمان، الأردن. rع. العبيدي، نماء جواد، (r ا ـ r) أثر العدالة التنظيمية وعلاقتها بالالتزام التنظيمي: دراسة ميدانية في وزارة التعليم العالي والبحث العلمي، مجلة

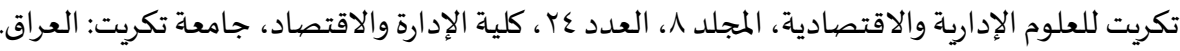

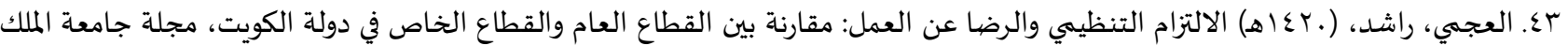

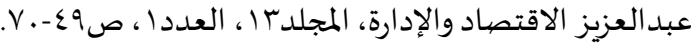

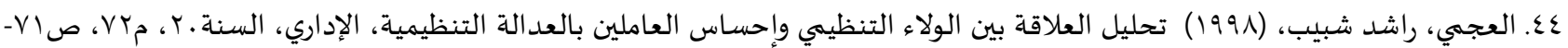




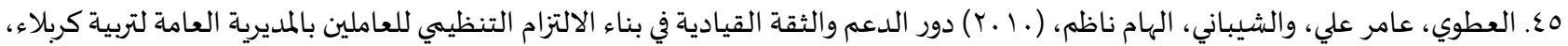

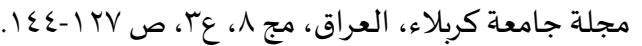

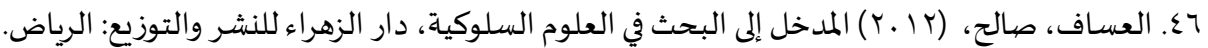

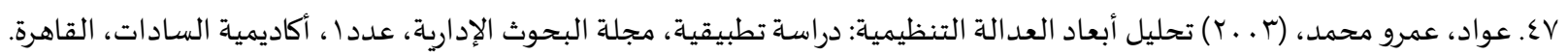

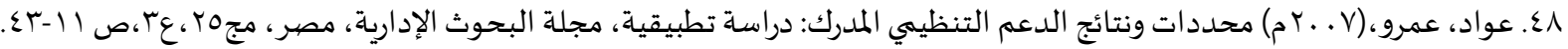

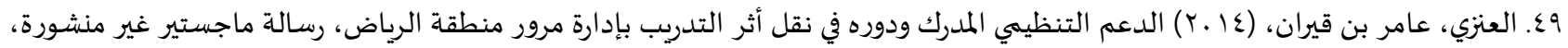
جامعة نايف للعلوم الأمنية. كلية العلوم الاجتماعية والإدارية، قسم العلوم الإدارية. الرياض، الماضية المملكة العربية السعودية.

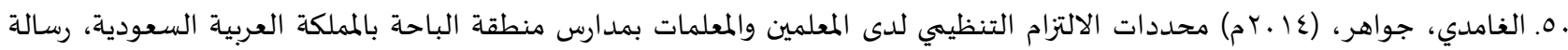
ماجستير غير منشورة

ا ه. الغامدي، سعيد محمد، (9 . . ب) النمط القيادي لمدير المدرسة وأثره على الالتزام التنظيمي للمعلمين بالمدارس الثانوية الحكومية بمحافظة جدة

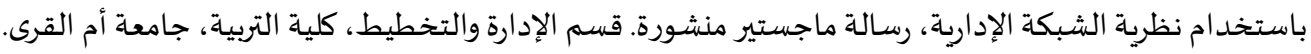

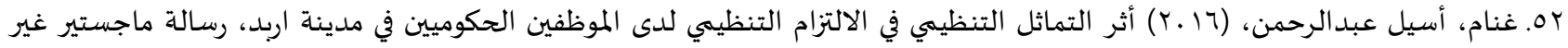
منشورة، كلية الاقتصياد والعلوم الادارية، جامعة اليرموك، الأردن.

ror. فارس، محمد، (عا .بم) العلاقة بين الثقة التنظيمية والالتزام التنظيمي: دراسـة ميدانية على جامعة الأزهر-غزة، مجلة الجامعة الإسلامية

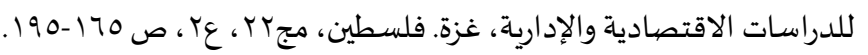

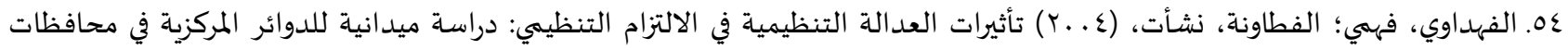

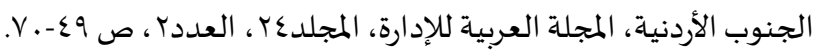

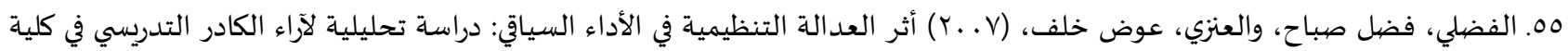

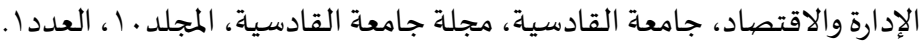

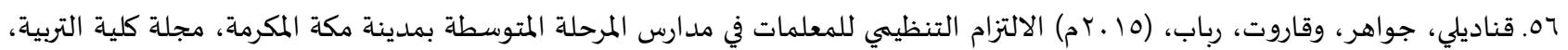

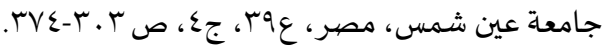

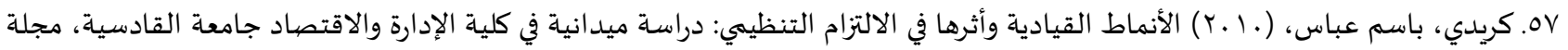

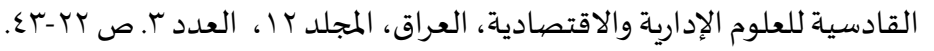

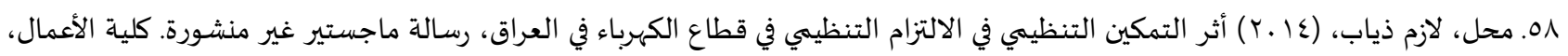
الجامعة الأردنية، الأردن.

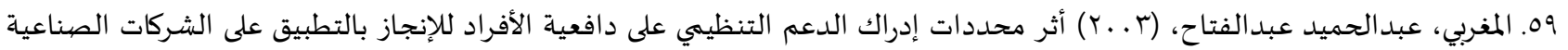

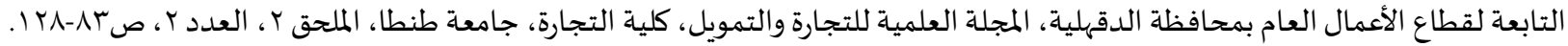

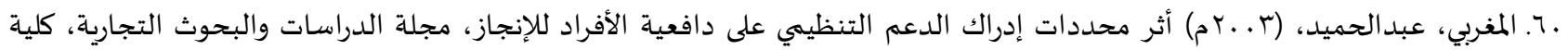

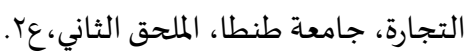
ا7. نوح، علياء حسني، (rا ـ بم) أثر الدعم التنظيمي في أداء الشركات وسلوك المواطنة التنظيمية: دراسة تطبيقية في الشركات الصناعية في مدينة

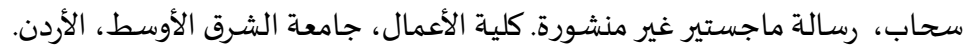

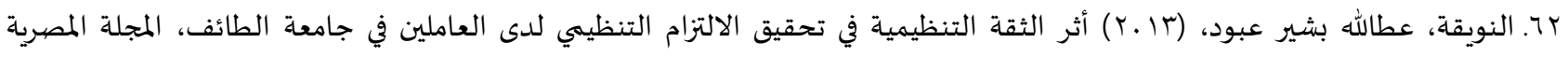

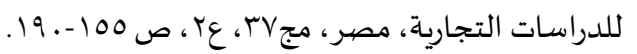

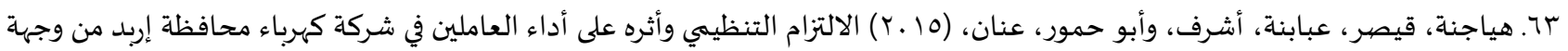

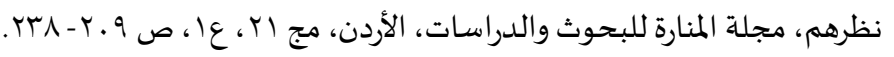

ثانياً: المراجع الأجنبية:

[1] Abdollahi. Farhad M.A, Piri. Moosa. \& Azimi. Mohammad M. A., The relationship between Perceived Organizational Support and Organizational Commitment among faculty members, Australian Journal of Basic and Applied Sciences, 7(4)(2013), 475-479.

[2] Arshadi. N. \&Hayavi. G., The Effect of Perceived Organizational Support on Affective Commitment and Job Performance: Mediating role of OBSE, Procedia- Social and Behavioral Sciences 84(2013), 739-743, https://doi.org/10.1016/j.sbspro.2013.06.637 
[3] Aube. Caroline, Rousseau. Vincent \& Morin. Estelle M., Perceived organizational support and organizational commitment The moderating effect of locus of control and work autonomy, Journal of Managerial Psychology, 22(5)(2007), 479-495, https://doi.org/10.1108/02683940710757209

[4] Blau. P., M., Exchange and Power in Social Life, New York John Willy, (1964)

[5] Celebi. Nurhayat, \& Korumaz. Mithat, Teachers' loyalty to their supervisors and organizational commitment, Educational Research and Reviews. 11(12)(2016), 1161-1167, https://doi.org/10.5897/err2016.2808

[6] Collon P. \& Davis E., High Involvement Management and Organizational Commitment, Academy of Management Journal. 37(1999), 823-825.

[7] Currie. P. \& Dollery. B. Organizational Commitment and Perceived Organizational Support in the NSW Police, Policing, An International Journal of Police Strategies \& Management, 29(4) (2006), 741-756, https://doi.org/10.1108/13639510610711637

[8] Downay. et al., The Keys To Retention Incentive, New York, Vol 175(2001)

[9] Eisenberger. R., Fasolo. P.M., \& Dawis - Lamastro. V, Effects of perceived organizational support on employee akikigence, innovation and commitment, journal of Applied Psychology, 53, 51 - 59.

[10] Eisenberger R, Cummings J, Armeli S \& Lynch P, Perceived organizational support, discretionary treatment, and job satisfaction, J Appl Psychol, 82(5)(1997), 812-820, https://doi.org/10.1037//00219010.82.5.812

[11] Eisenberger. R., \& et al., Reciprocation of Perceived Organizational Support, Journal of Applied Psycholog, 86(1)(2001), 42-51, https://doi.org/10.1037//0021-9010.86.1.42

[12] Eisenberger. R., Huntington. s., \& Soma. D., Perceived Organzational Support, Journal of Applied Psychology, 71(3)(1986), 500-507.

[13] Eisenberger. R., Stinglhamber. F., Vandenberghe. C., Sucharski., \& Rhoades. L., Perceived Supervisor Support: Contributions to Perceived Organizational Support and Employee Retentio, Journal of Applied Psycholog. 87(3)(2002), 565-573, https://doi.org/10.1037//0021-9010.87.3.565

[14] Farah. A., Moosa. P., \&Mohmmad. A., The relationship between Perceived Organizational Support and Organizational Commitment among faculty members, Australian Journal of Basic and Applied Sciences, 7(4)(2013), 475-479.

[15] Garipağaoğlu. Burçak Çağla., Examining Organzational Commitment of Privates School Teachers, Journal of Educational Studies in the World. 3(2)(2013).

[16] Hester Hulpia, Geert Devos, \& Hilde Van Keer, The Influence of Distributed Leadership on Teachers' Organization- al Commitment, A Multilevel Approach, Ghent University, (2010)

[17] Khan. Sadia., Organzational Commitment among Public and Private School Teachers, The International Journal of Indian Psychology. 2(3)(2015), 2349-3429.

[18] Knippenberg D.\& Sleebos. E., Organizational Identification versus Organizational Commitment: Selfdefinition, Social Exchange, and Job Attitudes, Journal of Organizational Behavior, 27(5)(2006), 571584, https://doi.org/10.1002/job.359

[19] Limpanitgul. T. Boonchoo. P. \& Photiyarach. S., Coworker Support and Organizational Commitment: A comparative study of Thai employees working in thai and American airlines, Journal of Hospitality and Tourism Management. 21(2014), 100-107, https://doi.org/10.1016/j.jhtm.2014.08.002 
[20] Liu. Yuwen., Perceived organizational support and expatriate organizational citizenship behavior: The mediating role of affective commitment towards the parent company, Personnel Review, 38(3)(2009), 307-319, https://doi.org/10.1108/00483480910943359

[21] Malik. Sadia, \&Noreen. Saima., Perceived Organizational Support as a Moderator of Affective Wellbeing and Occupational Stress among Teachers. Pakistan Journal of Commerce and Social, (2015)

[22] Mathieu. John E. \& Zajac, Dennis M., A review and meta-analysis of the antecedents, correlates, and consequences of organizational commitment, Psychological Bulletin, 108(2)(1990), 171-194, https://doi.org/10.1037//0033-2909.108.2.171

[23] Meyer, \& Allen, Trust as a mediator of the relationship between organizational justice and work outcomes: Test of a social exchange model, Journal of Organizational Behavior, 23(1997), pp267-285.

[24] Meyer. j, ALLen. N. \& smith , G., Commitment to organization and occupation ; Extension and test of three- component conceptualization on social behavior, Journal of Applied psychology, 78(4)(1993), 538- 551, https://doi.org/10.1037//0021-9010.78.4.538

[25] Moorman R. et al., Does Perceived Organizational Support Mediate the Relationship between Procedural Justice and Organizational Citizenship Behavior, Academy of Management Journal, 41(3)(1998), 351357, https://doi.org/10.5465/256913

[26] Nayir. Funda., The Relationship between Perceived Organizational Support and teachers' Organizational Commitment, Egitim Arastirmalari - Eurasian Journal of Educational Research, 48(2012), 97-116.

[27] Paille. Pascal, Grima. Francois, \& Bernardeau. Denis, When subordinates feel supported by managers: investigating the relationships between support, trust, commitment and outcomes, International Review of Administrative Sciences. 79(4)(2013). 681-700, https://doi.org/10.1177/0020852313501248

[28] Polat. Soner., The effect of organizational support; Perception of teachers on organizational trust perception of their schools, African Journal of Business Management, 4(14) (2010), 3134-3138.

[29] Rhoades. L. \& Eisenberger. R., Perceived organizational support: A review of the literature, Journal of Applied Psychology, 87(4)(2002), 698-714, https://doi.org/10.1037//0021-9010.87.4.698

[30] Shore. Lynn M. \& Wayne. Sandy J. (1993), Commitment and employee behavior: Comparison of affective commitment and continuance commitment with perceived organizational support, Journal of Applied Psychology, 78(5), 774-780, https://doi.org/10.1037//0021-9010.78.5.774

[31] Tanasky. T.W \& Cohen. D.J., The Relationship between Organization Support \& employee Development and Organizational Commitment: An Empirical Study, Human Recourses Development Quarterly, 12(3)(2001), 161- 285, https://doi.org/10.1002/hrdq.15

[32] Ucar. Dogan, \& Otken. Ayse Begum., Perceived Organizational Support and Organizational Commitment: The Mediating Role of Organization Based Self-Esteem. Dokuz Eylul Universitesi Iktisadi ve Idari Bilimler Fakultesi Dergisi. 25(2)(2010), 85-105.

[33] Van. Y Perean. et al., Towards a better understanding of the link between participation in decisionmaking and organizational citizenship behavior A multilevel analysis, Journal of Occupational and Organizational Psycholog, 72(3)(1999), 377-392, https://doi.org/10.1348/096317999166734

[34] Yahya. Khulida Kirana, Mansor. Fairuzah Zaharos \& Warokka, Ari., An Empirical Study on the Influence of Perceived Organizational Support on Academic Expatriates' Organizational Commitment, Journal of Organizational Management Studies, (2012), pp.14, https://doi.org/10.5171/2012.565439 

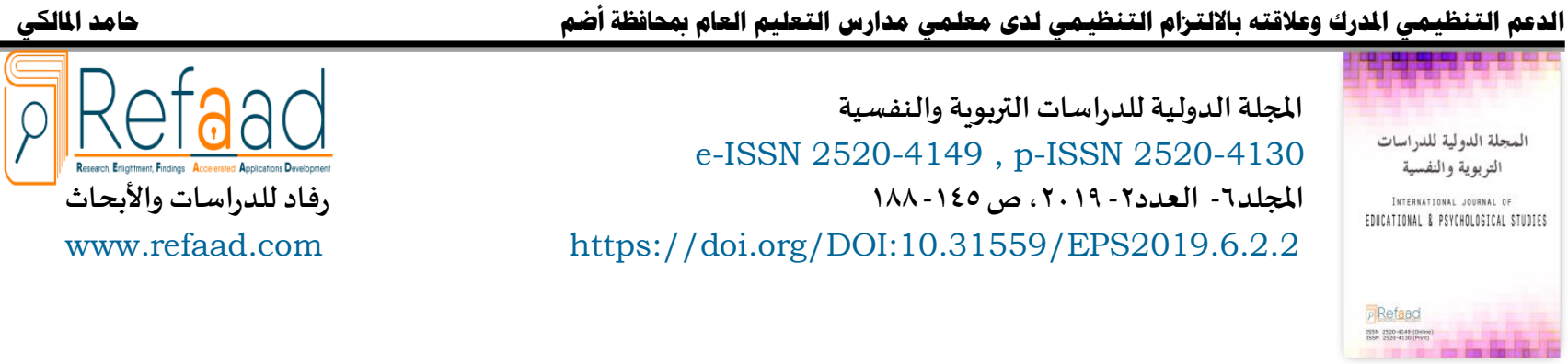

\title{
Perceived Organizational Support and its Relation to the Organizational Commitment of Teachers
}

\author{
Hamed Gafar AlMalki \\ Ministry of Education, KSA \\ 7galmalki@gmail.com
}

\begin{abstract}
The study aimed at Identify the level of organizational support that is understood in the general education schools in the governorate of Adham, and the level of organizational commitment of the teachers from their point of view, As well as to find out if there is a significant correlation between the level of organizational support and the level of organizational commitment of teachers of general education schools in, And the detection of differences of statistical significance between the average responses of teachers on their assessment of the level of organizational support perceived in their schools, and the level of their organizational commitment, which is due to the different personal variables(Qualification, years of experience). The study sample was selected in a comprehensive statistical manner, with $32 \%$ of the study population The most important study results:

- The level of organized organizational support in the general education schools in the governorate of A'mad has reached (significant) degree from their point of view.

- There is a correlation (positive) medium value and statistical significance at the level of significance (0.01) between the perceived organizational support and the level of organizational commitment of the teachers of general education schools in the province of Adam.

- There were no statistically significant differences at the level of significance (0.05) among the average responses of teachers about the level of the perceived organizational support of the teachers of the general education schools in the governorate of Adham due to the different variables of the study.
\end{abstract}

Keywords: Organizational support; Public Education; Organizational Commitment; Adham.

\section{References:}

[1] 'bdạl'zyz. Jmạl Syd, Drạsh Tḥlylyh Lmḥddạt Ạlạ̣ltzạm Ạltnzymy Llm' lmyn Bạltțbyq 'la Mdạrs Mhạfạty Ạlqạhrh Wạljyzh, Mjlï Ạlbḥwth Ạlạjạryh, Mṣr, 26(1)(2008), 122-163.

[2] 'bdạlsmy'. Jmạl 'bdạlḥmyd, Drạsh Tḥlylyh Lb ‘̣̣ Mḥddạt Wntạyjj Ạld'm Ạltnzymy Ạlmdrk Bạltṭ̣by 'la Mwẓfy Ạlqța Ạlḥkwmy Bạlmmlkh Ạl'rbyh Ạls 'wdyh, Mjlï Ạldrạsạt Ạlmạlyh Wạltjạryh, Klÿ̈ Tjạrẗ Bny Swyf, Jạm ‘̈ Alqạhrh, (2002),pp. 349-93.

[3] 'bdh. Nwr 'dnạn, Drjë Ạld'm Ạltnzymy W'lạqthạ Bmstwy Ạlth̄qh Ạltnzymyh Fy Ạljạm'ạt Ạlạ̉rdnyh,

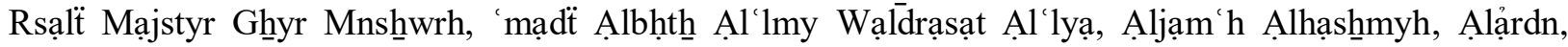
(2015)

[4] A.l'bydy. Nmạ’ Jwạd, Ạ̉tḥr Ạl dạlh Ạltnzymyh W' lạqthạ Bạlạltzạm Ạltnzymy: Drạsh Mydạnyh Fy Wzậr

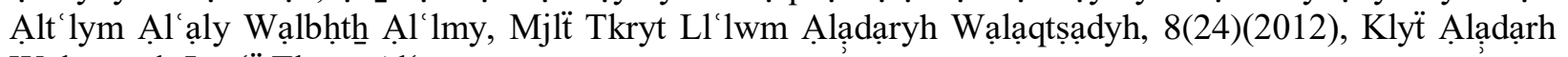
Wạlạqtṣạd, Jạm ‘̈ Tkryt: Ạl rạq. 
[5] 'bydạt. Dḥwqạn W'ds, 'bdạlrḥmn, \& 'bdạlḥ̣q, Kạyd, Ạlbḥth Ạl lmy- Mfhwmh Wạ̉dwạth Wạ̉sạlybh, Dạr Ạlfkr Llnsh̆r Wạltwzy': 'mạn, Ạlạ̉rdn, (2001)

[6] Ạl'jmy. Rạshnd, Ạlạltzạm Ạltnzymy Wạlrạa 'n Ạl'ml: Mqạrnh Byn Ạlqtạ' Ạl'ạm Wạlqtạ' Ạlkhạạ Fy Dwlẗ Ạlkwyt, Mjlẗ Jạm ‘̈ Ạlmlk ‘bdạl'zyz Ạlạqtṣạd Wạlạdạrh, 13(1)(1420h), Ș49-70.

[7] Ạl 'jmy. Rạshnd Shbbyb, Tḥlyl Ạl'lạqh Byn Ạlwlạ' Ạltnzymy Wạ̣sạs Ạl'ạmlyn Bạl'dạlh Ạltnzymyh, Ạlạdạry, A.lsnh20, 72(1998), pp.71-98.

[8] Ạ̉bw 'lạm. Rjạ’, Mnạhj Ạlbḥthn Fy Ạl'lwm Ạlnfsyh Wạltrbwyh, Ṭ 6, Dạr Ạlnsḥr Lljạm 'ạt: Ạlqạhrh, Mṣr, (2010).

[9] Ạl'nzy. 'ạmr Bn Qyrạn, Ạld'm Ạltnzymy Ạlmdrk Wdwrh Fy Nql Ạ̉thrr Ạltdryb Bạdạrẗ Mrwr Mnțqü

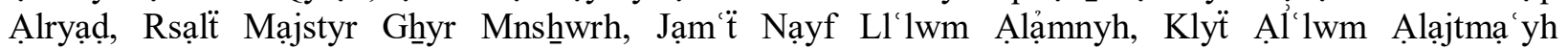
Wạlạdạryh, Qsm Ạl'lwm Ạlạdạryh, Ạlryạd, Ạlmmlkh Ạl'rbyh Ạls’ wdyh, (2014)

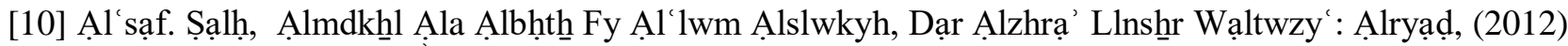

[11] Ạl'țwy. 'ạmr 'la, Wạlshhybạny, Ạlhạm Nạzm, Dwr Ạld'm Wạlthahh Ạlqyạdyh Fy Bnạ' Ạlạltzạm Ạltnzymy Ll'ạmlyn Bạlmdyryh Ạl'ạmh Ltrbyẗ Krblạ’, Mjlï Jạm ‘̈̈ Krblạ’, Ạl'rạq, 8(3)(2010), 127-144.

[12] 'wạd. 'mrw, Mḥddạt Wntạyj Ạld'm Ạltnzymy Ạlmdrk: Drạsh Tṭbyqyh, Mjlï Ạlbḥwth Ạlạdạryh, Mṣr, 25(3)(2007), 11-43.

[13] 'wạd. 'mrw Mḥmd, Tḥlyl Ạ̉b'ạd Ạl'dạlh Ạltnzyymyh: Drạsh Tṭbyqyh, Mjlï Ạlbḥwth Ạlạdạryh, 'dd1, Ạkạdymyh Ạlsạdạt, Ạlqạhrh, (2003)

[14] Abdollahi. Farhad M.A, Piri. Moosa. \& Azimi. Mohammad M. A., The relationship between Perceived Organizational Support and Organizational Commitment among faculty members, Australian Journal of Basic and Applied Sciences, 7(4)(2013), 475-479.

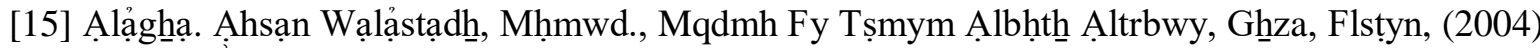

[16] Arshadi. N. \&Hayavi. G., The Effect of Perceived Organizational Support on Affective Commitment and Job Performance: Mediating role of OBSE, Procedia- Social and Behavioral Sciences 84(2013), 739-743, https://doi.org/10.1016/j.sbspro.2013.06.637

[17] Aube. Caroline, Rousseau. Vincent \& Morin. Estelle M., Perceived organizational support and organizational commitment The moderating effect of locus of control and work autonomy, Journal of Managerial Psychology, 22(5)(2007), 479-495, https://doi.org/10.1108/02683940710757209

[18] Blau. P., M., Exchange and Power in Social Life, New York John Willy, (1964)

[19] Bțạynh. Lw̉y Fwạz, Ạ̉hbr Ạltmkyn Wạld 'm Ạltnzymy Fy Ạlslwk Ạlạbdạ y Ll'ạmlyn Fy Ạlqtạa Ạl'ạm Ạlạ̉rdny: Drạsh Mydạnyh Mn Wjhẗ Nẓr Mdyry Ạlmdyryạt Ạlḥkwmyh Fy Ạqlym Ạlsḥmạl, Rsạlt Mạjstyr Ghyyr Mnshwwrh, Klyẗ Ạlạqtșạd Wạl'lwm Ạlạdạryh, Jạm ‘̈ Ạlyrmwk, Ạlạ̉rdn, (2008)

[20] Ạlbws'ydy. Bdr, Mda Mshạrkë Al ạmlyn Fy Ạtkḥạhh Ạlqrạrạt Ạlạdạryh Wạ̉tḥrhạ Fy Ạlạltzạm Ạltnzymy

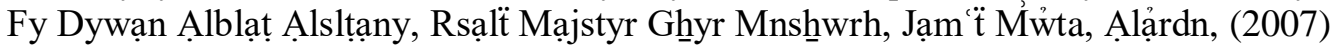

[21] Celebi. Nurhayat, \& Korumaz. Mithat, Teachers' loyalty to their supervisors and organizational commitment, Educational Research and Reviews. 11(12)(2016), 1161-1167, https://doi.org/10.5897/err2016.2808

[22] Collon P. \& Davis E., High Involvement Management and Organizational Commitment, Academy of Management Journal. 37(1999), 823-825. 
[23] Currie. P. \& Dollery. B. Organizational Commitment and Perceived Organizational Support in the NSW Police, Policing, An International Journal of Police Strategies \& Management, 29(4) (2006), 741-756, https://doi.org/10.1108/13639510610711637

[24] Dhlyz. Khạld \& ḥmd. Mḥmd, Ạ̉tḥr Ạlạrtbạt Ạlwzyyfy Wạld 'm Ạltnzymy Ạlmdrk 'la Ạlạ̉dạ' Ạlwzyfy Fy

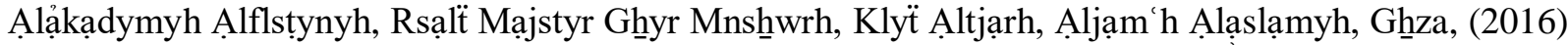

[25] Dȟyb. Mḥmd Rshhdy\& ạls 'wd, Rạtb, Drjë Mmạrsẗ Qym Ạl'ml Lda Mdyry Ạltrbyh Wạlt'lym Fy Ạlạ̉rdn W'lạqth Bdrjï Ạlạltzạm Ạltnzymy Lrw̉sạ’ Ạlạ̉qsạm Ạl'ạmlyn M`hm, Mjlï Ạl'lwm Ạltrbwyh, Ạlạ̉rdn, 41(2014), Mlḥq, Ș 494-512.

[26] Ạ̉bw Dhym. Njạ̈ Ạbrạhym, Dwr Mmạrsạt Adaạr Ạlmwạrd Ạlbshryh Fy Thqyq Ạl'dạlh Altnzymyh: Mn

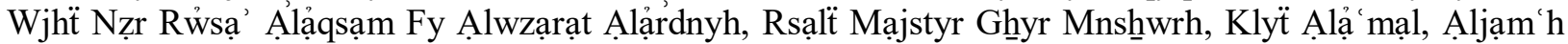
Ạlạ̉rdnyh, Ạlạ̉rdn, (2011)

[27] Downay. et al., The Keys To Retention Incentive, New York, Vol 175(2001)

[28] Eisenberger. R., Fasolo. P.M., \& Dawis - Lamastro. V, Effects of perceived organizational support on employee akikigence, innovation and commitment, journal of Applied Psychology, 53, 51 - 59.

[29] Eisenberger R, Cummings J, Armeli S \& Lynch P, Perceived organizational support, discretionary treatment, and job satisfaction, J Appl Psychol, 82(5)(1997), 812-820, https://doi.org/10.1037//00219010.82.5.812

[30] Eisenberger. R., \& et al., Reciprocation of Perceived Organizational Support, Journal of Applied Psycholog, 86(1)(2001), 42-51, https://doi.org/10.1037//0021-9010.86.1.42

[31] Eisenberger. R., Huntington. s., \& Soma. D., Perceived Organzational Support, Journal of Applied Psychology, 71(3)(1986), 500-507.

[32] Eisenberger. R., Stinglhamber. F., Vandenberghe. C., Sucharski., \& Rhoades. L., Perceived Supervisor Support: Contributions to Perceived Organizational Support and Employee Retentio, Journal of Applied Psycholog. 87(3)(2002), 565-573, https://doi.org/10.1037//0021-9010.87.3.565

[33] Farah. A., Moosa. P., \&Mohmmad. A., The relationship between Perceived Organizational Support and Organizational Commitment among faculty members, Australian Journal of Basic and Applied Sciences, 7(4)(2013), 475-479.

[34] Fạrs. Mḥmd, Ạl'lạqh Byn Ạltḥqh Ạltnzymyh Wạlạltzạm Ạltnzymy: Drạsh Mydạnyh 'la Jạm đạ ẠlạzhrGhzza, Mjlï Ạljạm h Ạlạslạmyh Lldrạsạt Ạlạqtṣạdyh Wạlạdạryh, Ghzza. Flsțyn, 22(2)(2014), Ș 165-195.

[35] Ạlfụly. Fụl Șbạh, \& ạl 'nzy. 'wḍ Kḥlf, Ạ̉tḥr Ạl'dạlh Ạltnzymyh Fy Ạlạ̉dạ' Ạlsyạqyy: Drạsh Tḥlylyh Lậrạ'

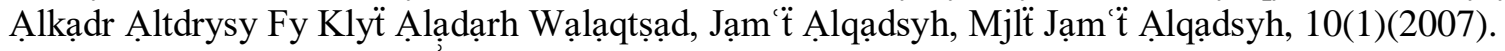

[36] Ạlfhdạwy. Fhmy; Ạlfțawnh, Nshạat, Tạ̉thnyrạt Al dạlh Ạltnzymyh Fy Ạlạltzạm Ạltnzymy: Drạsh Mydạnyh Lldwạỷr Ạlmrkzyh Fy Mhạfzạt Ạljnwb Ạlạ̉rdnyh, Ạlmjlh Ạl'rbyh Llạjdạrh, 24(2)(2004), 49-70.

[37] Garipağaoğlu. Burçak Çağla., Examining Organzational Commitment of Privates School Teachers, Journal of Educational Studies in the World. 3(2)(2013).

[38] A.lghạmdy. Jwạhr, Mḥddạt Ạlạltzạm Ạltnzymy Lda Ạlm 'lmyn Wạlm lmạt Bmdạrs Mnṭqï Ạlbạhh Bạlmmlkh Ạl'rbyh Ạls’wdyh, Rsạlẗ Mạjstyr Ghyr Mnshwwrh, (2014)

[39] Ạlgḥạmdy. S'yd Mḥmd, Ạlnmt Ạlqyạdy Lmdyr Ạlmdrsh Wạ̉thrrh 'la Ạlạltzạm Ạltnzymy Llm'lmyn

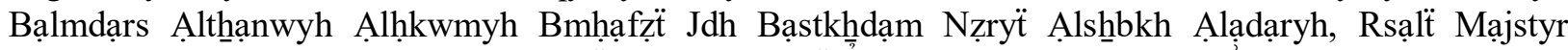

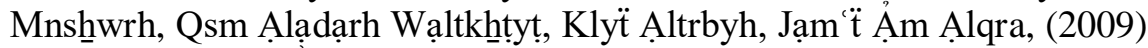


[40] Ghnạm. Ạ̉syl 'bdạlrḥmn, Ạ̉hhr Ạltmạthַl Ạltnzymy Fy Ạlạltzạm Ạltnzymy Lda Ạlmwẓfyn Ạlḥkwmyyn

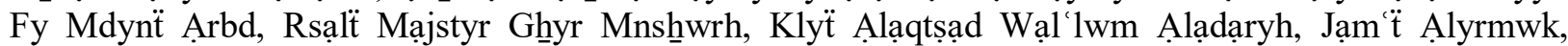
Ạlạ̉rdn, (2016)

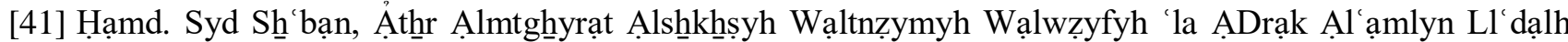
Ạltnzymyh: Drạsh Mydạnyh, Mjlẗ Ạlmḥạsbh Wạlạdạrh Wạltạ̉myn, Ạl'dd 41', Jhạz Ạldrạsạt Ạl'lyạ Wạlbḥwth̆, Klÿ̈ Ạltjạrh, Jạm đ̈ Ạlqạhrh, (2002)

[42] Hạmd. S'yd, Ạtḥr 'lạqü Ạlfrd Brỷysh Wạdrạkh Lld'm Ạltnzymy Kmtgḥyryn Wsytyn 'la Ạl'lạqh Byn Ạl'dạlh ẠltnzymyhWslwk Ạlmwạtnh Ạltnzymyh- Drạsh Mydạnyh, Klyẗ Ạltjạrh, Jạm đ̣̈ Ạlạ̉zhr, (2003)

[43] Hester Hulpia, Geert Devos, \& Hilde Van Keer, The Influence of Distributed Leadership on Teachers' Organization- al Commitment, A Multilevel Approach, Ghent University, (2010)

[44] Ḥmạdạt. Mḥmd Ḥsn, Qym Ạl'ml Wạlạltzạm Ạltnzyymy Lda Ạlmdyryn Wạlm'lmyn Fy Ạlmdạrs, Ṭ4, 'mạn: Drạ Allhạamd, (2006)

[45] Ḥmwdh. 'bdạlnạșr, Bnạ' Nmwdḥj Ạnḥdạry Mt'dd Ạlmtgḥyrạt Wạlmrạḥl Lltnbw̉ Bạlạltzạm Ạltnẓymy Wậthạrh Drạsh Mydạnyh Mṭbqh 'la B'ḍ Ạltnzymạt Ạlmṣryd, Ạlmjlh Ạl'lmyh, Jạm đạ Ạ̉sywț, Mṣr, 13(19)(1993), 64-118.

[46] Ḥnwnh. Sạmy, Qyạs Mstwa Ạlạltzạm Ạltnzymy Lda Ạl'ạmlyn Bạljạm ạt Ạlflsțynyh Bqța Ghnza, Rsạlẗ Mạjstyr Gḥyr Mnsḥwrh, Ạljạm h Ạlạslạmyh, Ghzza, (2006)

[47] Alhrạḥ̣hhh. Mḥmd 'bwd, Al'lạqh Byn Ạlạ̉nmạt Ạlqyạdyh Ạlty Ymạrshạ Mdyrw Ạlmdạrs Wmstwy Ạlạltzạm Ạltnzymy Llm'lmyn Fy Mdạrs Mdyryë Ạltrbyh Wạlt'lym Fy Mhạfật Ạlțfylh, Mjlï Ạl'lwm Ạltrbwyh Wạlnfsyh, Ạlbḥryn, 7(1)(2006),13-41.

[48] Ạlḥrạhḥhh. Mḥmd, Wạlhyty, Șlạh Ạldyn, Ạ̉thor Ạltmkyn Ạlạdạry Wạld'm Ạltnzymy Fy Ạlslwk Ạlạbdạ y Kmạ Yrạh Ạl'ạmlwn Fy Shrrkë Ạlạtșạlạt Ạlạ̉rdnyh: Drạsh Mydạnyh, Mjlt Ạl'lwm Ạlạdạryh, Ạ̉ạ̉rdn, 33(2)(2006), 240-266.

[49] Hsn. Nhla Syd, Tmkyn M'lmy Mdạrs Ạlthạnwy Ạl'ạm Bmhạaẓ̂t Ạlqạhrh Ạlkbry Lthquyq Ạltzạmhm Ạltnzymy: Drạsh Mydạnyh, Mjlï Ạltrbyh, Mṣr, 16(40)(2013), 131-218.

[50] Hyạjnh. Qyṣr, 'bạbnh, Ạ̉shrrf, \& ạ̉bw Ḥmwr, 'nạn, Ạlạltzạm Ạltnzymy Wạ̉thַrh 'la Ạ̉dạ' Ạl ạmlyn Fy Shrrk̈̈ Khrbạ' Mhạfặt ẠRbd Mn Wjhẗ Nẓrhm, Mjlt Ạlmnạrh Llbḥwth Wạldrạsạt, Ạlạ̉rdn, 21(1)(2015), 209- 238.

[51] Aljạbry. Ms`wd, Ạlạltzạm Ạltnzymy Lda M'lmy Wm`lmạt Alt'lym Ạlạ̉sạsy (5-10) W'lạth Bmstwy

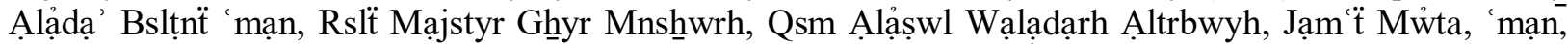
(2012).

[52] Ạ̉bw Jạsr. Sạbryn, Ạ̉th̄r Adrạk Ạl'ạmlyn Ll'dạlh Ạltnzymyh 'la Ạlạ̉dạ' Ạlsyạqy: Drạsh Tṭbyqyh 'la Mwẓfy Wzạaạt Ạlslțh Ạlflsțynyh, Rsạlẗ Mạjstyr Ghyr Mnshwwrh, Ạljạm h Ạlạislạmyh, Ghzza, (2010)

[53] Ạljrjạwy. Zyạd, Alqwạa 'd Ạlmnhjyh Lbnạ’ Alạstbyạn. Ț2, Mṭb ‘̈ Ạ̉bnạ’ Aljrạh: Ghnza, Flsțyn, (2010)

[54] Jwdh. Mḥfwz Ạ̉hmd, Tṭbyq Nzạam Qyạs Ạlạ̉dạ’ Ạlmtwạzn Wạathِrh Fy Ạlạltzạm Ạlmw̉ssy Ll'ạmlyn Fy Shrrk̈̈ Ạlạ̉lmnywm Ạlạ̉rdnyh, Ạlmjlh Ạlạ̉rdnyh Ll' lwm Ạltqnyh, Ạl'rạq, 22(2)(2008), 273-292.

[55] Khan. Sadia., Organzational Commitment among Public and Private School Teachers, The International Journal of Indian Psychology. 2(3)(2015), 2349-3429. 
[56] Kḥ̣̂yr. Ngḥmh 'bạs, Wậkḥrwn, Ạlạltzạm Ạltnzymy Wfạ lyë Ạlmnẓmh Drạsh Mqạrnh Byn Ạlklyạt

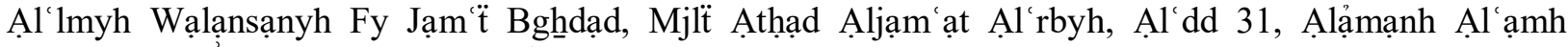
Lạthạd Ạljạm 'ạt Ạl'rbyh, 'mạn: Ạlặrdn, (1996)

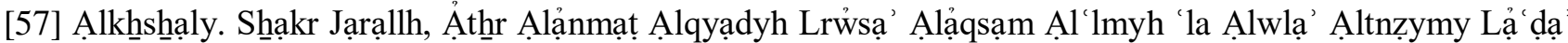
Hyỷt Ạltdrys Fy Ạljạm ạt Ạlạ̉rdnyh Ạlkh̄ạsh, Ạlmjlh Ạlạ̉rdnyh Ll'lwm Ạltțbyqyh- Ạl'lwm ẠlạiNsạnyh, 16(1)(2003), 124-152.

[58] Knippenberg D.\& Sleebos. E., Organizational Identification versus Organizational Commitment: Selfdefinition, Social Exchange, and Job Attitudes, Journal of Organizational Behavior, 27(5)(2006), 571584, https://doi.org/10.1002/job.359

[59] Krydy. Bạsm 'bạs, Ạlạ̉nmạt Ạlqyạddyh Wạ̉tḥrhạ Fy Ạlạltzạm Ạltnzymy: Drạsh Mydạnyh Fy Klyë Ạlạdạrh Wạlạqtṣạd Jạm ‘ُ Ạlqạdsyh, Mjlẗ Ạlqạdsyh Ll'lwm Ạlạdạryh Wạlạqtṣạdyh, Ạl'rạq, 12(3)(2010), 22-43.

[60] Limpanitgul. T. Boonchoo. P. \& Photiyarach. S., Coworker Support and Organizational Commitment: A comparative study of Thai employees working in thai and American airlines, Journal of Hospitality and Tourism Management. 21(2014), 100-107, https://doi.org/10.1016/j.jhtm.2014.08.002

[61] Liu. Yuwen., Perceived organizational support and expatriate organizational citizenship behavior: The mediating role of affective commitment towards the parent company, Personnel Review, 38(3)(2009), 307-319, https://doi.org/10.1108/00483480910943359

[62] Malik. Sadia, \&Noreen. Saima., Perceived Organizational Support as a Moderator of Affective Wellbeing and Occupational Stress among Teachers. Pakistan Journal of Commerce and Social, (2015)

[63] Mathieu. John E. \& Zajac, Dennis M., A review and meta-analysis of the antecedents, correlates, and consequences of organizational commitment, Psychological Bulletin, 108(2)(1990), 171-194, https://doi.org/10.1037//0033-2909.108.2.171

[64] Meyer, \& Allen, Trust as a mediator of the relationship between organizational justice and work outcomes: Test of a social exchange model, Journal of Organizational Behavior, 23(1997), pp267-285.

[65] Meyer. j, ALLen. N. \& smith , G., Commitment to organization and occupation ; Extension and test of three- component conceptualization on social behavior, Journal of Applied psychology, 78(4)(1993), 538- 551, https://doi.org/10.1037//0021-9010.78.4.538

[66] Ạlmgḥrby. 'bdạlhmmyd 'bdạlftạh, Ạ̉tḥr Mḥddạt Adrạk Ạld'm Ạltnzymy 'la Dạf yë Ạlậfrạd Llạjạaz

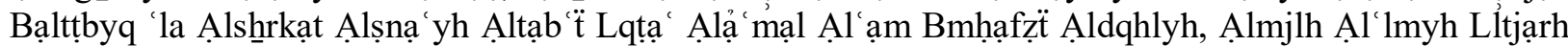
Wạltmwyl, Klÿ̈ Ạltjạrh, Jạm‘̈̈ Ṭnṭa, 2(2)(2003), 83-128.

[67] Ạlmgh̆rby, 'bdạlḥmyd, Ạ̉tḥr Mḥddạt ADrạk Ạld'm Ạltnzymy 'la Dạf yü Ạlạ̉frạd Llạnjạz, Mjlï Ạldrạsạt

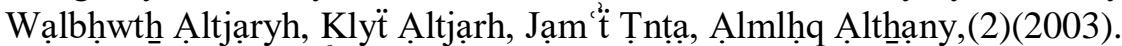

[68] Mḥl. Lạzm Dḥyạb, Ạtḥr Ạltmkyn Ạltnzymy Fy Ạlạltzạm Ạltnzymy Fy Qța 'Ạlkhrbạ’ Fy Ạl rạq, Rsạlẗ Mạjstyr Ghyr Mnshwwrh. Klyë Ạlạ̉ mạl, Aljạm’h Ạlạ̉rdnyh, Ạlạ̉rdn, (2014)

[69] Ạbn Mnẓwr, Lsạn Ạl’rb, Ạlqạhrh, Dạr Ạlm’ạrf, (2011)

[70] Moorman R. et al., Does Perceived Organizational Support Mediate the Relationship between Procedural Justice and Organizational Citizenship Behavior, Academy of Management Journal, 41(3)(1998), 351357, https://doi.org/10.5465/256913

[71] Nayir. Funda., The Relationship between Perceived Organizational Support and teachers' Organizational Commitment, Egitim Arastirmalari - Eurasian Journal of Educational Research, 48(2012), 97-116. 
[72] Nwḥ. 'lyạ’ Ḥsny, Ạ̉tḥr Ạld 'm Ạltnzymy Fy Ạ̉dạ’ Ạlsḥrkạt Wslwk Ạlmwạtnhh Ạltnzymyh: Drạsh Tṭbyqyh

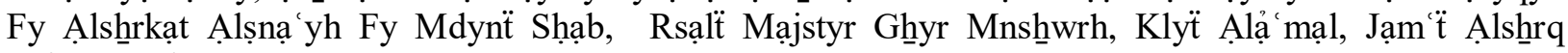
Ạlạ̉wsṭ, Ạlạ̉rdn, (2013)

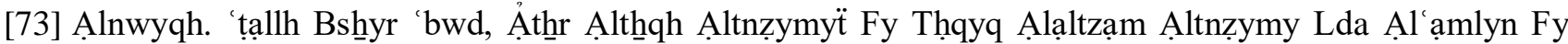
Jạm ẗ Ạlțạyf, Ạlmjlh Ạlmșryh Lldrạsạt Ạltjạryh, Mṣr, 37(2)(2013), 155-190.

[74] Ạ̉bw Ndạ. Sạmya, Tḥlyl 'lạqï B'ḍ Ạlmtghyrạt Ạlsḥkḥsyh Wạ̉nmạt Ạlqyạadh Bạlạltzạm Ạltnzymy

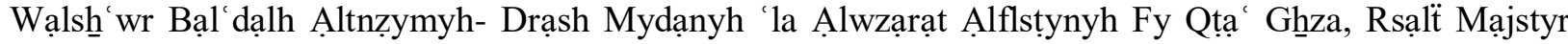

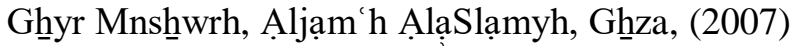

[75] Paille. Pascal, Grima. Francois, \& Bernardeau. Denis, When subordinates feel supported by managers: investigating the relationships between support, trust, commitment and outcomes, International Review of Administrative Sciences. 79(4)(2013). 681-700, https://doi.org/10.1177/0020852313501248

[76] Polat. Soner., The effect of organizational support; Perception of teachers on organizational trust perception of their schools, African Journal of Business Management, 4(14) (2010), 3134-3138.

[77] Qnạdyly. Jwạhr, \& qạrwt. Rbạb, Allạltzạm Ạltnzymy Llm lmạt Fy Mdạrs Ạlmrḥlh Ạlmtwsṭh Bmdynẗ Mkh Ạlmkrmh, Mjlï Klÿ̈ Ạltrbyh, Jạm ‘̈ 'yn Sh̆ms, Mṣr, 39(4)(2015), 303-374.

[78] Rhoades. L. \& Eisenberger. R., Perceived organizational support: A review of the literature, Journal of Applied Psychology, 87(4)(2002), 698-714, https://doi.org/10.1037//0021-9010.87.4.698

[79] Rsḩyd. Mạzn, Ạld'm Ạltnzymy Ạlmdrk Wạlạ̉b ạd Ạlmt'ddh Llwlạ’ Ạltnzymy, Ạlmjlh Ạl'rbyh Ll'lwm Ạlạdạryh, Jạm ‘̆ Ạlmlk S’wd, Ạlryạḍ, 11(1)(2004).

[80] Ryạn, 'ạdl Ryạn Mḥmd, Ạ̉ḥnr Adrạk Ạlạ̉frạd Lld 'm Ạltnzymy Kmtghnyr Wsyṭ 'la Ạl lạqh Byn Ạlạltzạm Ạltnzymy Ạlwjdạny Wb đọ Ạlmtghyrạt Ạlmwqfyh- Drạsh Mydạnyh, Ạlmjlh Ạl'lmyh Lklyẗ Ạltjạrh, Jạm ‘̈̈ 'yn Shms, Ạl'dd 9, Ạlsnh 19(2000), 40-69.

[81] Ạlṣbạghn. Shwwqy Mḥmd, Ạl'lạqh Byn Ạlfrd Wrỷysh Wạld'm Ạltnzymy Ạlmdrk Wtạ̉thyyrhmạ 'la Ạlwlạ' Ạltnzymy Ll'ạmlyn Bmstsh̆fyạt Jạm đ̈ Ạlmnwfyh, Mjlï Ậạq Jdydẗ Lldrạsạt Ạltjạryh, Mṣr, 21(3)(2009), 329-347.

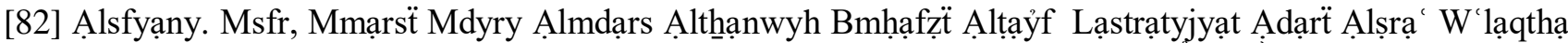
Bạlạltzạm Ạltnzymy Lda Ạlm lmyn, Rsạlẗ Mạjstyr Ghyr Mnshwwrh, Jạm ‘̆ Ạm Ạ̉lqra, Mkh Ạlmkrmh, Ạls'wdyh, (2013)

[83] Sh 'bạn, S yd Hạmd, Ạ̉tḥr 'lạqë Ạlfrd Rỷysh WạDrạkh Lld'm Ạltnzymy Kmtghyryn Wsyṭnn 'la Ạl'lạqh Byn Ạl'dạlh Ạltnzymyh Wslwk Ạlmwạtnh Ạltnzymyh, Ạlmjlh Ạl'lmyh Llbḥwth Wạldrạsạt Ạltjạryh, Klyë Ạltjậrh Wạdạrt Ạlạ̉ mạl, Jạm đ̈ Ḥlwạn, (17)(2007), 59-105.

[84] Ạlsh 'lạn. Mḍạy, Ạld 'm Ạltnzymy Ạlmdrk Ldwạf' Ạl'ml Lda Ạlmwẓật Ạlạdạryạt Bklyt Ạlậdạb

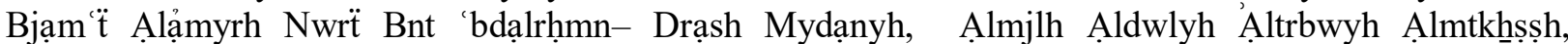
3(12)(2014), 149-171.

[85] Shhạb. Fạdya Ạbrạhym, Ạlțwyr Ạltnzymy: Ạlqwạ'd Ạlnẓryh Wạlmmạrsạt Ạltțbyqyh, 'mạn: Ạlạ̉kạdymywn Llnshr Wạltwzy', (2011)

[86] Ạlsḥmry. Alạ̉dhm, Alạltzạm Ạltnzymy W'lạqth Bạlrḍạ Ạlwzyfy Lda Mdyry Ạlmdạrs Ạlḥwwmyh Bmnṭ̣t Hạỷl, Mjlï Mstqbl Ạltrbyh Ạl'rbyh, Mṣr, 22(96)(2015), 119-190.

[87] Ạlshntyty. Mḥmwd, Dwr Ạld 'm Ạltnzymy Ạlmdrk Kmtgḥyr Wsyṭ Fy Ạl'lạqh Byn Ạl'dạlh Ạltnzymyh Wslwk Ạlmwạtnh Altnzymyh (Drạsh Tṭbyqyh 'la Al'ạmlyn Bwzạrẗ Ạldạkhllyh- Ghzza), Mjlï Ạljạm h Ạlạslạmyh Lldrạsạt Ạlạqtșạdyh Wạlạdạryh, Ghzza, 23(2)(2015), 31-59. 
[88] Shore. Lynn M. \& Wayne. Sandy J. (1993), Commitment and employee behavior: Comparison of affective commitment and continuance commitment with perceived organizational support, Journal of Applied Psychology, 78(5), 774-780, https://doi.org/10.1037//0021-9010.78.5.774

[89] Ạlsḩwạdfy. Mḥmd 'mry, Dwr Mnạkh Ạlạtṣạl Fy Tshkkyl Ạlạltzạm Ạltnzyymy, Mjlï Ạlbḥwth Ạltjạryh, Jạm ‘̈ Ạlzqạzyq, Mṣr, 24(1)(2002), 250-297.

[90] Ạlskạrnh. Blạl Kḥlf, Mḥddạt Adrạk Ạld'm Ạltnzymy Wạ̉tḥrhạ Fy Dạf'yë Ạlạnjạz: Drạsh Mydạnyh 'la

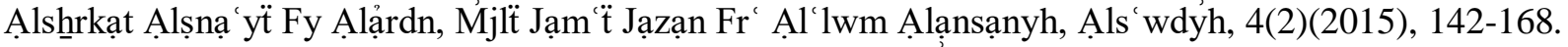

[91] Ạlslwm. Tạrq, \& ạl' dạylh. 'ly, Ạ̉hăr Adrạk Ạld'm Ạltnzymy Fy Slwk Ạlmwạṭnh Ạltnzymyh Lda Ạ 'ḍa'

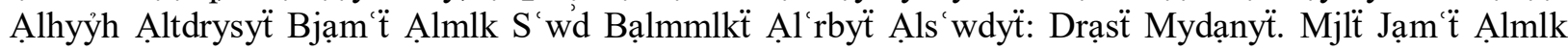
S’wd. M25. Al’ lwm Ạlạdạrÿ̈(1). Alryạḍ. Ș Ș163-188, (2013)

[92] Tanasky. T.W \& Cohen. D.J., The Relationship between Organization Support \& employee Development and Organizational Commitment: An Empirical Study, Human Recourses Development Quarterly, 12(3)(2001), 161- 285, https://doi.org/10.1002/hrdq.15

[93] Ạ̉bw Tạyh. Bndr, Ạ̉tḥr Ạl'dạlh Ạltnzymyh 'la Slwk Ạlmwạtnh Ạltnzymyh Fy Mrạkz Ạlwzạạ̣t Ạlḥkwmyẗ Fy Ạlạ̉rdn, Mjlẗ Ạljạm ‘h Ạlạslạmyh Lldrạsạt Ạlạqtṣạdyh Wạlạdạryh, Ạl'dd Ạlthạny, (2012)

[94] Van. Y Perean. et al., Towards a better understanding of the link between participation in decisionmaking and organizational citizenship behavior A multilevel analysis, Journal of Occupational and Organizational Psycholog, 72(3)(1999), 377-392, https://doi.org/10.1348/096317999166734

[95] Ucar. Dogan, \& Otken. Ayse Begum., Perceived Organizational Support and Organizational Commitment: The Mediating Role of Organization Based Self-Esteem. Dokuz Eylul Universitesi Iktisadi ve Idari Bilimler Fakultesi Dergisi. 25(2)(2010), 85-105.

[96] Yahya. Khulida Kirana, Mansor. Fairuzah Zaharos \& Warokka, Ari., An Empirical Study on the Influence of Perceived Organizational Support on Academic Expatriates' Organizational Commitment, Journal of Organizational Management Studies, (2012), pp.14, https://doi.org/10.5171/2012.565439

[97] Zạyd. 'ạdl Mḥmd, Tḥlyl Ạl'lạqh Byn Ạ̉sạlyb Mrạqbë Ạlạ̉dạ' Ạlwzyfy Wậ̣sạs Ạl'ạmlyn Bạl'dạlh Ạltnzymyh, A.lmjlh Ạl'rbyh Ll'lwm Ạlạdạryh, 2(2)(1995). 